\title{
CONSTITUTIONAL PERSPECTIVES ON GOVERNMENTAL DECISIONS AFFECTING HUMAN LIFE AND HEALTH*
}

\author{
JAMES F. BLuMSTEIN $\dagger$
}

\section{INTRODUCTION}

\section{A. The Basic Dilemma}

Although we do not like to admit it openly, it is nevertheless true that we as a society willingly undertake risks as one acceptable cost of securing the benefits of an industrial way of life. ${ }^{1}$ The law of torts, for example, early evolved a "reasonable man" standard as an accommodation between interests in economic productivity and safety; in effect, this standard allows for more accidents (and thus more death) than would occur under a more stringent standard. ${ }^{2}$ If it be acknowledged that the law allows-even encourages-accidents that might be preventable from a technological viewpoint, ${ }^{3}$ it becomes apparent that government implicitly has decided not to assign a value to life that is beyond price in all circumstances.

Recognizing that government often makes the choice to favor more

\footnotetext{
* Research for the article was supported by the Vanderbilt Institute for Public Policy Studies and, in its final stages, by the Department of Community Medicine, Dartmouth Medical School. The author gratefully acknowledges the research assistance of Andrew Shookhoff, a May 1977 graduate of the Vanderbilt Law School, and Craig Gabbert, a May 1976 graduate of the Vanderbilt Law School; the helpful comments of Laurence H. Tribe, Robert Bastress, Randall R. Bovbjerg, Jonathan 1. Charney, Jan G. Deutsch, Donald J. Hall, Robert D. Kamenshine, L. Harold Levinson, and Thomas R. Mccoy, all of whom read earlier versions of the manuscript; and the constructive editorial assistance of Philip J. Cook, James W. Vaupel, and Peter Buck.

$\dagger$ Professor of Law, Vanderbilt Law School, and Senior Research Fellow, Vanderbilt Institute for Public Policy Studies.

1. See generally Blumstein, Inflation and Quality: The Case of PSROs, in HeALTH: A VICTIM OR Cause of Inflation? 245, 262-73 (M. Zubkoff ed. 1976): Calabresi, The Decision for Accidents: An Approach to Nonfault Allocation of Costs, 78 HaRv. L. REv. 713 (1965); Havighurst \& Blumstein, Coping with Quality/Cost Trade-offs in Medical Care: The Role of PSROs, 70 Nw. U.L. Rev. 6, $21-23$ (1975) [hereinafter cited as Havighurst \& Blumstein].

2. See G. Calabresi, The Costs of Accidents (1970); R. Posner, Economic analysis of the LAw (1972); Calabresi, Optimal Deterrence and Accidents: To Fleming James, Jr., 84 Yale L.J. 656 (1975).

3. See Oi, On The Economics of Industrial Safety, 38 Law \& Contemp. Prob. 669 (1974): Industrial Union Dep't, AFL-CIO v. Hodgson, 499 F.2d 467, 477-78 (D.C. Cir. 1974). See generally Wall Street Journal, May 12, 1976, at 4, cols. 2-3 (report on recommendation of Council on Wage and Price Stability against proposed occupational safety standard on grounds of excessive costs).
} 
accidents ${ }^{4}$ when they occur at a "statistical" level, ${ }^{5}$ policy analysts become puzzled by the apparent inconsistency of governmental behavior when, in cases where identifiable lives ${ }^{6}$ are at stake, government finds it difficult to apply similar criteria. ${ }^{7}$ Thus, for example, we can see as an empirical matter that government (acting through the prosecutor and its welfare system) seems to assign a higher value to the life of an irreversibly comatose Karen Quinlan than to a productive Mississippi delta farmer who might be spared from encephalitis with proper mosquito control spraying, or to an asbestos worker who might be saved from debilitating illness by more stringent safety regulations. ${ }^{8}$ Assuming that differential life valuations are, to some extent at least, permissible, ${ }^{9}$ one can reasonably ask on what dimension government determines to expend scarce resources on a patient whose likelihood of "salvageability" $1 "$ is very low, while at the same time sacrificing increments of

4. Automobile safety is an obvious area in which accidents are often "favored." Empirical evidence shows that higher speed limits are correlated with increased accident and death rates. Why Auto Deaths Plummeted in 74, U.S. News \& WORLD ReP., Jan. 6, 1975, at 21. Yet, when legislation in response to the energy crisis lowered speed limits, there was considerable opposition by truckers, for whom the lower speed meant reduced incomes. N.Y. Times, Jan. 29, 1974, at 16, col. 5 (trucker shot during protest of lower speed limits). Despite the lower risks, these drivers argued that the cost in living standards was too expensive-they were willing to make a choice for more accidents in light of the economic benefits associated with higher risk. Similar popular opposition to the mandatory safety-belt interlock system resulted in congressional reversal of an administratively set safety rule. 15 U.S.C. § $1410 \mathrm{~b}$ (Supp. 1975). Other values-including convenience-interceded to outweigh safety factors. See generally W. Lowrance, Of Acceptable Risk: Science \& the Determination of Safety (1976): Acton, Valuing Lifesaving-Alternatives and Some Measurements, 40 Law \& Contemp. Prob. no. 4, at _._. (1976).

5. See C. Fried, An Anatomy of Values: Problems of Personal and Social Choice (1970); Fried, The Value of Life, 82 Harv. L. REv. 1415 (1969); Havighurst \& Blumstein.

6. Examples of "identifiable lives" are "an intercontinental balloonist or boatman lost at sea"; "statistical lives" are those "which predictably will be lost as a result of some societal undertaking such as maintenance of an automobile-based economy or the construction of a bridge or cunnel." Havighurst \& Blumstein 21-22.

7. See Zeckhauser, Coverage for Catastrophic Illness, 21 PuB. PouICy 149 (1973) [hereinafter cited as Zeckhauser, Catastrophic Illness]; Zeckhauser, Procedures of Valuing Lives, 23 PuB. Policy 419 (1975) [hereinafter cited as Zeckhauser, Valuing Lives].

8. In re Quinlan, 137 N.J. Super. 227, 348 A.2d 801 (1975), modified, 70 N.J. 10, 355 A.2d 647 (1976); Industrial Union Dep't, AFL-CIO v. Hodgson, 499 F.2d 467 (D.C. Cir. 1974); N.Y. Times, Sept. 7, 1975, at 60, col. 1 (report of the threat to Mississippi delta farmers posed by encephalitis-spreading mosquitoes).

9. Differential life valuations have long been accepted in wrongful death cases, where the amount of recovery varies with the earnings potential of the deceased. S. SPEISER, RECOVERY FOR Wrongful DeATh $\$ 3.8$ (1975). As a corollary of this, at least two sex-specific differentials are apparently permissible. First, projection of earning capacity may rely on sex-specific data for predicting earning potential; this would, on a historical basis, diminish the amount of wrongful death recoveries for females. Secondly, life expectancy may vary according to sex, with women typically living longer. This could affect awards in two ways. If a jury believed the additional years of life for a female were economically unproductive, then the award would be lower, reflecting the years of retirement where outflow exceeded earnings. Longer life could, however, be associated with additional productivity, which assumption would increase monetary judgments. See generally id. $\$ 3.23$.

10. See Crane, Decisions to Treat Critically Ill Patients: A Comparison of Social Versus Medical 
safety for asbestos workers ${ }^{11}$ or ignoring the risks faced by the delta farmer in order to achieve other economic objectives.

In cases such as that of Karen Quinlan, where public attention is focused on the plight of the unfortunate individual, important symbolic values seem to intercede. ${ }^{12}$ The myth of a democratic government, supporting human life at any cost, is a value to which we like to adhere. In general, however, we are unwilling to pay the price necessary to achieve that goal. ${ }^{13}$ When a breach of this value is threatened in stark terms, much more may be involved than valuing life. Society's humanitarian self-image may be at stake, and we may be willing to expend considerable sums of money, ostensibly to save a life, but also to preserve a valuable myth. ${ }^{14}$

As one prominent commentator has concluded, there are potential "external costs involved in the manner, the process, through which a life is valued or taken." 15 This observation is important for the policy analyst-and for the constitutional lawyer-because institutional arrangements at the structural level can have rather substantial impacts on ultimate societal resource allocation decisions. ${ }^{16}$ There may be important results that stem from the choice of one procedure rather than another for assigning values to human life. And the decision whether to make this valuation process either visible or explicit ${ }^{17}$ may itself have a significant effect on the ultimate value assigned to human life. ${ }^{18}$

Failure to articulate openly and in easily understood terms what values are to be assigned to whose life-and on what criteria-is not without risk, however. There is the possibility of both inefficiency and inequity. ${ }^{19}$ Indeed, visibility and openness are crucial ingredients in the lawyer's and the policy analyst's traditional recipe books for assuring accountability and improving

Considerations, 53 Milbank Memorial Fund Q.: Health and Soc'y 1, 4 (1975). See also In re Quinlan, 70 N.J. 10, 355 A.2d 647 (1976).

11. Industrial Union Dep't, AFL-CIO v. Hodgson, 499 F.2d 467 (D.C. Cir. 1974).

12. In re Quinlan, 70 N.J. 10, 335 A.2d 647 (1976); Blumstein, supra note 1; Blumstein \& Zubkoff, Public Choice in Health Problems, Politics and Perspectives on Formulating National Health Policy, Int'l J. of Health Services (forthcoming); Zeckhauser, Catastrophic Illness, supra note 7; Zeckhauser, Valuing Lives, supra note 7.

13. Zeckhauser, Catastrophic Illness, supra note 7; Calabresi, Commentary, in Inst. OF MED., Nat'l ACad. Of Sciences, Ethics of Health Care 48-55 (L. Tancredi ed. 1974) [hereinafter cited as Calabresi, Commentary]; G. Calabresi, Toward a Theory of Tragic Choices (April 1973) (lectures on file at the University of Pennsylvania Law School) [hereinafter cited as G. Calabresi, Tragic Choices].

14. Zeckhauser, Catastrophic Illness, supra note 7.

15. Calabresi, Commentary, supra note 13 , at 53.

16. Id.; G. Calabresi, Tragic Choices, supra note 13.

17. J. Katz \& A. Capron, Catastrophic Diseases: Who Decides What? 3 (1975) [hereinafter cited as Katz \& CaPron]; Note, Due Process in the Allocation of Scarce Life Saving Medical Resources, 84 YALE L.J. 1734, 1749 (1975) [hereinafter cited as Note, Due Process].

18. Zeckhauser, Catastrophic Illness, supra note 7; Blumstein \& Zubkoff, supra note 12; Calabresi, Commentan, supra note 13.

19. Katz \& Capron, supra note 17; Note, Due Process, supra note 17. 
efficiency (or rationality). But in a life-or-death situation, procedure itself has such an impact in determining what substantive issues matter and how much they matter that traditional notions must be reexamined. This article attempts to add to the policy dialogue by focusing on some issues that might be identified from a constitutional analysis.

Examination of constitutional perspectives on government decisions that affect human life can make at least two different types of important contributions to a policy discussion. It can alert policy analysts to duties and limitations that the Constitution might impose on governmental decision making in this sensitive area. Since constitutional analysis requires consideration of a broad spectrum of factors that must ultimately enter into any governmental policy decision valuing human life, it can serve as an extremely useful backdrop against which policy analysts can apply their various methodologies. ${ }^{20}$ Thus, an analysis of constitutional considerations can help to illuminate some of the competing value issues raised by governmental decision making which implicitly or explicitly values human life.

\section{B. Application of Constitutional Doctrine}

Courts, applying constitutional doctrines, figure in vital decisions in a number of ways. Under traditional notions of due process, courts will often establish minimal procedural requirements by which governmental agencies (or private institutions imbued with sufficient "publicness") ${ }^{21}$ must make decisions. Procedural due process issues typically focus on claimed deprivations of individual entitlements; these are usually created by government and protected by the Constitution as interests in "life, liberty, or property." These cases are generally adjudicatory in nature and involve individualized determinations of eligibility or entitlement.

Another type of judicial intervention arises in situations where constitutional values such as equal protection impose restrictions or constraints on substantive policy determinations made by governments. For example, if a governmental decision maker were to propose a safety rule that all whites were to be saved first in case of fire, the equal protection clause would bar implementation of that policy as impermissibly discriminatory. Similarly, the Constitution can serve to define scopes of responsibility for decision-making, ${ }^{22}$ allocating some decisional authority to private actors in situations where governmental choice making would be peculiarly inappropriate and arguably in-

20. Note, Legal Analysis and Population Control: The Problem of Coercion, 84 Harv. L. Rev. 1856, 1862-65 (1971).

21. See text at I.A.1 and note 457 infra.

22. Tribe, Structural Due Process, 10 Harv. Civ. Rights-Civ. Lib. L. Rev. 269 (1975). See also Tribe, Childhood, Suspect Classifications, and Conclusive Presumptions: Three Linked Riddles, 39 LAw \& Contemp. Prob. no. 3, at 8 (1975); Tribe, The Supreme Court, 1972 Term-Foreword: Toward a Model of Roles in the Due Process of Life and Law, 87 HARv. L. Rev. I (1973). 
trusive on values of individual or family freedom. The emerging constitutional doctrine of privacy, applied by the United States Supreme Court in the abortion cases $^{23}$ and more recently by the New Jersey Supreme Court in the Karen Quinlan ${ }^{24}$ case, is an indication of this form of constitutionally imposed limitation on governmental decision-making authority.

A third type of constitutional decision involves imposition of a duty on government to provide a service where specified persons are unable to purchase that service in the market place. Thus, in some situations, and for some impecunious individuals, the Constitution places an obligation on the state to provide an adequate level of services to meet basic needs.

This article will examine in detail the types of issues that can arise under these three types of constitutional claims. It will also address in a more normative manner the considerations that dictate judicial reticence in this sensitive area, where core societal tenets necessarily come into conflict. As a vehicle for discussing these constitutional issues, it will make use of two hypothetical fact situations, which will serve as a recurring referent throughout the article.

(a) John Jones is a hemophiliac. He wants the government to pay for his treatment in case he should become injured. Assume that sufficient quantities of blood and appropriate medication can "save" Jones if he has a severe bleeding episode. Should the government through its budget be obligated as a matter of constitutional law to provide these treatments? ${ }^{25}$ Would Jones' level of income or wealth be relevant? ${ }^{26}$ Of what significance is it that the federal government would furnish funds if Jones had the "proper" disease (i.e., kidney failure), but that such funds are unavailable for treatment of hemophilia?27 Similarly, assume

23. Doe v. Bolton, 410 U.S. 179 (1973); Roe v. Wade, 410 U.S. 113 (1973).

24. In re Quinlan, 70 N.J. 10, 355 A.2d 647 (1976).

25. Though courts today probably would not find for $\mathrm{Mr}$. Jones, it is an interesting (and revealing) exercise to think the problem through from a constitutional perspective.

26. Would Jones's claim be stronger if he were well-to-do? He could then argue that the economic cost of his treatment would be a worthwhile economic investment for government. Or would Jones's claim be stronger if he were underprivileged, so he could argue that the governmental decision was, in his case at least, a matter of life or death?

27. The Social Security Act Amendments of 1972, 42 U.S.C. $\S \S 426(f)-426(g)$ (1974), provide funding for most victims of end-stage renal disease. The financing mechanism is expanded coverage under the Medicare program; simultaneously, Medicare eligibility was extended to those who were covered by the Social Security disability insurance program. In effect, end-stage renal disease was defined as a covered disability, even though it did not meet some of the specific requirements established for other disabilities.

In July, 1975, Congress did provide for modest funding of hemophilia diagnostic and treatment centers. Section 606 of Public Law 94-63, 89 Stat. 304, 350, codified at 42 U.S.C. § 300c-21 (Supp. 1977), established a program of grants to centers that provided services to hemophilia patients within a specified geographic area. The act authorized expenditures of $\$ 3$ million in fiscal 1976 and $\$ 4$ million in fiscal 1977. Actual expenditures in fiscal 1976 were $\$ 2.5$ million to fund seventeen hemophilia centers. In fiscal $1977, \$ 3$ million was appropriated for support of these seventeen centers. 
that Jones is able to establish that prisoners routinely receive heroic treatment where their case is brought to public attention, and that courts have ordered prisons to provide high quality medical services to inmates. ${ }^{28}$ Would those decisions be controlling? Further, Jones notes that since the capital punishment decision by the Supreme Court in $1972,{ }^{29}$ the government has had to spend much more per capita to maintain and support such notorious inmates as Richard Speck (the mass murderer of eight student nurses in Chicago). If the Court requires society to expend relatively large sums of money to keep convicted murderers alive, Jones urges, why won't it require society to spend at least as much on keeping hemophiliacs alive-especially since the disease is genetically determined and the victim (Jones) has committed no antisocial acts. Jones becomes particularly resentful when informed that the case for government-provided treatment probably would be stronger were he in fact a convicted felon and a life tenant in the penitentiary. ${ }^{30}$

The hemophilia program is of considerably more limited scope than the kidney program, which establishes a federal financial commitment to pay for treatment by approved providers. The hemophilia center grant program is limited by the appropriations process, and in fact centers have been funded in only the following states: California (3); Florida; lowa; Massachusetts; Minnesota; North Carolina; New York (3); Oregon; Pennsylvania; Texas (2); Wisconsin; Washington, D.C. The illustration in the text assumes, of course, that Jones lives outside of a geographic treatment zone. Naturally, a victim could move, but the discussion, because heuristic in intent, does not consider this option.

28. James v. Wallace, 406 F. Supp. 318 (M.D. Ala. 1976); Newman v. Alabama, 349 F. Supp. 278 (M.D. Ala. 1972), aff'd in part, 503 F.2d 1320 (5th Cir. 1974), cert. denied, 421 U.S. 948 (1975).

29. Furman v. Georgia, 408 U.S. 238 (1972)

30. See Estelle v. Gamble, 429 U.S. 97 (1976). Gamble involved a federal civil rights complaint by a prisoner who claimed that inadequate treatment of a back injury constituted cruel and unusual punishment in violation of the eighth amendment. The Court ruled against the prisoner, finding that at most he had a claim for medical malpractice cognizable in state courts. However, in reaching this conclusion, Justice Marshall distinguished the prisoner's claim, which was based on poor quality treatment and bad-medical judgment, from an allegation of "deliberate indifference to a prisoner's serious illness" and his "serious medical needs," which would constitute cruel and unusual punishment under the eighth amendment. 429 U.S. at 104-05. The Court found that government has an "obligation to provide medical care for those whom it is punishing by incarceration." Id. at 103. The Court's rationale was that refusal to provide treatment to a prisoner who, because of his incarceration, cannot care for himself, is an "infliction" of "unnecessary suffering" which is "inconsistent with contemporary standards of decency," since an "inmate must rely on prison authorities to treat his medical needs." Id.

While the scope of the ruling in Gamble is uncertain since the discussion of cruel and unusual punishment came in the context of denying the plaintiff's claim, it is clear that any benefit from the decision will be confined to those who are being criminally punished. This was made explicit in Ingraham v. Wright, $97 \mathrm{~S}$. Ct. 1401 (1977), where the Court refused to apply the cruel and unusual punishment concept outside of the criminal law area. In Ingraham, a public school pupil argued that corporal punishment (paddling) was prohibited by the eighth amendment. Justice Powell expressly distinguished Gamble on the ground that the "prisoner and the schoolchild stand in wholly different circumstances, separated by the harsh facts of criminal conviction and incarceration." 97 S. Ct. at 1411 . Thus, the refusal to provide medical treatment, according to Justice 
(b) Sarah and Samuel Smith are twins, each with serious heart disease. Their medical condition is virtually the same, and there is a prospective donor whose heart would be suitable, medically, for transplantation in either Sarah or Samuel. How will a decision be made as to which sibling gets the transplant? What procedures will apply? What criteria will be used? Should it matter whether government is somehow implicated in the decision? Can a decision-making body consider nonmedical factors (e.g., whether either is married or has children? Whether one is wealthier than the other or more intelligent?)? Must a decision maker consider such nonmedical factors? Must the criteria be articulated and written out in advance? Should such decisions be left in the hands of the family and children themselves?

\section{The Structure of the Analysis}

The next section of this article considers the requirements of procedural due process: To what extent procedures must be established, standards articulated, and notice and hearing provided, when scarce life-saving medical services are allocated among competing applicants.

The final section focuses on the role that courts play in resource allocation decisions; it examines first the question whether, and if so the extent to which, government has an affirmative duty to guarantee access to necessary life-saving medical services. It next discusses the limitations on government decision making imposed by the fourteenth amendment: To what extent does governmental expenditure of funds on life-saving medical services for some beneficiaries give rise to a constitutional claim for similar expenditures for other groups? What criteria of classification will be acceptable to justify differential treatment? Finally, the problem of formulating remedies in this sensitive area is outlined; attention is focused on the institutional limitations that courts face in their participation in the life-valuing process.

The Requirements of Due Process

The due process notion is very much situational, depending on context for its definition. Notice and hearing are rudimentary components, mirroring the adversarial tradition of our jurisprudence. However, other elements vary widely in differing factual settings. Three sets of issues arise: (1) whether procedural constitutional safeguards are warranted at all; (2) whether government must establish in advance standards by which to allocate scarce life-

Powell, may properly be viewed as a part of society's punishment of a convicted criminal; but absent criminal conviction, after compliance with the procedural safeguards associated with criminal prosecutions, "the Eighth Amendment is inapplicable." Id. at 1412 \& n.40. 
saving medical resources and, if so, whether prospective applicants must be informed of those standards; and (3) whether such procedural components as counsel, written record, and impartial decision maker are necessary in the case of allocating scarce life-saving medical resources. These issues will be cuscussed in turn below.

The fundamental importance of process in the life-saving context warrants examining the requirements of procedural due process in some detail. Until recently, access to scarce renal dialysis machines was governed by an informal choice mechanism; ${ }^{31}$ policies designed to limit the costs of treating catastrophically expensive diseases may result in the need to make a large number of such "tragic choices"32 in the future. ${ }^{33}$ While the Smith case, involving twins competing for a heart transplant, is unique, its basic features are sufficiently similar to a wide range of other cases to make it a good prototypal example from which to extrapolate.

\section{A. Threshold Issues}

Procedural due process safeguards attach only where two threshold requirements are met. First, there must be sufficient involvement by government ("state action") so that it is responsible for any arguable infringements of constitutionally protected interests. Secondly, an interest entitled to constitutional protection such as "life, liberty, or property" must be identified before courts will impose traditional constraints of due process. If these initial hurdles are passed, then the courts must determine what processes are "due" under any given set of circumstances.

\section{State Action}

The fourteenth amendment provides individuals certain protections against activities for which responsibility can appropriately be assigned to the state. This element of governmental answerability must be present before courts determine what protections the Constitution might establish on an individual's behalf. ${ }^{34}$

Thus, in the case of two competing claimants for a heart transplant, a court would first ask whether constitutional safeguards apply at all. Suppose that the two patients were at a government owned and operated hospital,

31. See Rettig, Valuing Lines: The Policy Debate on Patient Care Financing for Victims of End-Stage Renal Disease, 40 Law \& Contemp. Prob. no. 4, at 196 (1976).

32. The term was coined in this context by Professor Guido Calabresi. See note 106 infra; G. Calabresi, Tragic Choices.

33. See Havighurst, Blumstein, \& Bovbjerg, Strategies in Underwriting the Costs of Calastrophic Disease, 40 Law \& Contemp. Prob. no. 4, at 122 (1976).

34. See, e.g., Hudgens v. NLRB, 424 U.S. 507 (1976); Jackson v. Metropolitan Edison Co., 419 U.S. 345 (1974); Lloyd Corp., Ltd. v. Tanner, 407 U.S. $55 \mathrm{l}$ (1972); Moose Lodge No. 107 v. Irvis, 407 U.S. 163 (1972); Burton v. Wilmington Parking Authority, 365 U.S. 715 (1961). See generally Comment, State Action: A Pathology and a Proposed Cure, 64 Calif. L. Rev. 146 (1976). 
where the state's involvement is beyond question; then, the case would proceed directly to what constitutional protections, if any, ${ }^{\mathbf{3 5}}$ were applicable. If, however, the patients were at a private hospital, an initial issue would be whether, under a variety of tests, constitutional principles were implicated at all. ${ }^{36} \mathrm{~A}$ finding of no state action will normally terminate the constitutional analysis under the fourteenth amendment. ${ }^{37}$

The significance of this threshold question is illustrated by judicial treatment of cases involving hospital decisions to disallow abortions. Although the circuit courts of appeals have not been in agreement in defining the scope of state action, ${ }^{38}$ many have found receipt of general federal funds insufficient to establish enough of a relationship to trigger constitutional protection. ${ }^{39}$ Finding no "symbiotic relationship" 40 between government and the hospital and no connection between the county and the hospital's abortion policy, these courts have held constitutional safeguards inapplicable. ${ }^{41}$ Where, however, a hospital is found not to be "private" but "public," courts have not allowed enforcement of policies against abortions. ${ }^{42}$ Since government must

35. See discussion in text at section 1.A.2. infra.

36. See, e.g., cases cited at note 34 supra.

37. Somewhat different issues arise where Congress acts pursuant to section five of the fourteenth amendment. See United States v. Guest, 383 U.S. 745 (1966).

38. Contrast, for example, the Fourth Circuit's readiness to find state action based on the receipt of Hill-Burton funds, Christhilf v. Annapolis Emergency Hosp. Ass'n, 496 F.2d 174 (4th Cir. 1974), Sams v. Ohio Valley Gen. Hosp. Ass'n, 413 F.2d 826 (4th Cir. 1969). Simkins v. Moses H. Cone Memorial Hosp., 323 F.2d 959 (4th Cir. 1963), with the reluctance of other circuit courts to find state action where there is considerable government financial assistance and regulation, Taylor v. St. Vincent's Hosp., 523 F.2d 75 (9th Cir. 1975); Greco v. Orange County Memorial Hosp. Corp., 513 F.2d 873 (5th Cir. 1975), cert. denied, 423 U.S. 1000 (1975); Ascherman v. Presbyterian Hosp. of Pac. Medical Center, 507 F.2d 1103 (9th Cir. 1974); Doe v. Bellin Memorial Hosp., 479 F.2d -756 (7th Cir. 1973).

39. The Fifth Circuit has even concluded that no state action is involved when land for a hospital is donated to a county by private donors, the county leases the land to a nonprofit hospital corporation for one dollar per year, and the county raises $\$ 1.7$ million in a bond issue and has received $\$ 1.25$ million from the federal government to build the hospital. Greco $v$. Orange County Memorial Hosp. Corp., 513 F.2d 873 (5th Cir. 1975), cert. denied, 423 U.S. 1000 (1975).

40. Moose Lodge No. 107 v. Irvis, 407 U.S. 163, 175 (1972). See also Jackson v. Metropolitan Edison Co., 419 U.S. 345 (1974).

41. See, e.g., Greco v. Orange County Memorial Hosp. Corp., 513 F.2d 873 (5th Cir. 1975), cert. denied, 423 U.S 1000 (1975).

42. See Doe v. Poelker, 515 F.2d 541 (8th Cir. 1975); Hathaway v. Worcester City Hosp., 475 F.2d 701 (1st Cir. 1973); McCabe v. Nassau County Medical Center, 453 F.2d 698 (2d Cir. 1971).

Much after completion of this article, but prior to publication, the Supreme Court reversed Doe v. Poelker. Poelker v. Doe, 45 U.S.L.W. 4794 (U.S. June 20, 1977). On that same day, the Court ruled that a state's decision not to pay for nontherapeutic abortions, even when it pays for childbirth, does not violate the Constitution. Maher v. Roe, 45 U.S.L.W. 4787 (U.S. June 20, 1977) reversing E remanding Roe v. Norton, 408 F. Supp. 660 (D. Conn. 1975). In Poelker, the city of St. Louis, through a policy directive by its mayor, prohibited abortions at city owned and operated hospitals "except where there was a threat of grave physiological injury or death to the mother." 45 U.S.L.W. at 4794-95. Also, under the prevailing staffing practice, doctors and medical stu- 
allow private choice to prevail in the abortion context, ${ }^{43}$ it would be inappropriate for government (through a hospital for which responsibility could be assigned to the state) to restrict the private abortion choice.

In the abortion situation, the finding of state action is determinative of the outcome. In other contexts, however, a finding of state action only advances the analysis to the next stage: What obligations or constraints does the Constitution impose on governmental behavior? To the extent that governmental involvement in and responsibility for decisions allocating life-saving medical equipment may implicate symbolic values and thereby alter the outcomes of allocative choices, the state action determination will be important and the criteria for making that determination warrant further scrutiny. ${ }^{44}$

dents at the hospital's obstetrics-gynecology clinic were recruited from a Jesuit-operated medical school opposed to abortion. Id. at 4795. The Court saw the constitutional issue in Poelker as "identical in principle with that presented by a State's refusal to provide medicaid benefits for abortions while providing them for childbirth." Id. Since in Maher the Court held that state choice valid, the Court concluded that the city of St. Louis could decide "to provide publicly financed hospital services for childbirth without providing corresponding services for nontherapeutic abortions." Id.

The Court's decision in Poelker and Maher alter the conclusion in text that the abortion situation reflects an example where a finding of state action is determinative of the substantive outcome. The general point, however, remains valid-that where a choice made by a state would violate the constitution, a finding of state action will be determinative. The clearest example, of course, would be a policy of race discrimination to the disadvantage of blacks. Once state action is found, in such a case, a finding of unconstitutionality would inexorably follow. Simkins v. Moses $\mathrm{H}$. Cone Memorial Hosp., 323 F.2d 959 (4th Cir. 1963).

43. Doe v. Bolton, 410 U.S. 179 (1973); Roe v. Wade, 410 U.S. 113 (1973).

44. The Second Circuit has been most articulate in its analysis of the considerations involved in a "state action" determination. In Wahba v. New York Univ., 492 F.2d 96 (2d Cir. 1973), cert. denied, 419 U.S. 874 (1974), the court noted that the "determination of governmental action . . hinges on the weighing of a number of variables, principally the degree of government involvement, the offensiveness of the conduct, and the value of preserving a private sector free from constitutional requirements applicable to governmental institutions." 492 F.2d at 102.

The court elaborated its view in Weise v. Syracuse Univ., 522 F.2d 397 (2d Cir. 1975): "[A] consideration of whether there is a state action necessarily entails a balancing process . . As the conduct complained of becomes more offensive, and as the nature of the dispute becomes more amenable to resolution by a court, the more appropriate it is to subject the issue to judicial scrutiny." Id. at 406 .

Five factors seem particularly important to the Second Circuit in a determination of "state action":

(1) the degree to which the "private" organization is dependent on governmental aid; (2) the extent and intrusiveness of the governmental regulatory scheme; (3) whether that scheme connotes government approval of the activity or whether the assistance is merely provided to all without such connotation; (4) the extent to which the organization serves a public function or acts as a surrogate for the state; (5) whether the organization has legitimate claims to recognition as a "private" organization in associational or other constitutional terms.

Jackson v. Statler Foundation, 496 F.2d 623, 629 (2d Cir. 1974), cert. denied, 420 U.S. 927 (1975).

Review of the case law indicates that statistically courts have been more likely to find "state action" where racial discrimination is involved than where other constitutional claims (due process, freedom of speech) are at issue. See 496 F.2d at 628. But see Jackson v. Metropolitan Edison Co., 419 U.S. 345, 373-74 (1974) (Marshall, J., dissenting) (the Supreme Court has never explicitly recognized that standards for state action should vary depending on the constitutional claim asserted). Cf. note 457 infra. 


\section{Deprivation of Constitutionally Protected Interests}

If government is implicated, the question becomes whether our competing heart transplant patients are entitled to notice and a hearing on their claim. The Supreme Court has stated that, before determining what kind of process, if any, is "due" under the fourteenth amendment, ${ }^{45}$ it must find that a constitutionally protected interest will be denied or deprived. ${ }^{46}$ The Court has argued that the appropriate inquiry is what the "nature" 47 of the individual interest is; it must be an interest to which a person has a legitimate claim of legal entitlement, not a unilateral expectation. ${ }^{48}$

The analytical framework for this determination was established by the Supreme Court in Board of Regents $\%$ Roth, ${ }^{49}$ which involved a claim by a non-tenured college professor that he was entitled to notice and hearing to dispute nonrenewal of his contract. The Court emphasized that due process protections apply only where there is some interest in "life, liberty, or property." These three interests are discussed, in reverse order, below.

\section{a. The "Property" Interest}

In the Roth case, the Court focused on the property interest and stressed that the protectable interest is not created by the Constitution itself but typically by an autonomous source such as statutory (or customary) law. The due process guarantee is thus directed at protecting against arbitrary governmental action that "seeks to remove or significantly alter that protected status."50"

45. Mathew's v. Eldridge, 424 U.S. 319 (1976). See also Wolff v. McDonnell, 418 U.S. 539

(1974); Gagnon v. Scarpelli, 411 U.S. 778 (1973); Morrissey v. Brewer, 408 U.S. 471 (1972).

46. Board of Regents v. Roth, 408 U.S. 564, 569 (1972).

47. Id. at 571 .

48. Id. at 577. See also Paul v. Davis, 424 U.S. 693 (1976).

49. 408 U.S. 564 (1972).

50. Paul v. Davis, 424 U.S. at 710 . The Court in Paul seems to have limited some of the language in Roth, where the Court had said:

Property interests, of course, are not created by the Constitution. Rather, they are created and their dimensions are defined by existing rules or understandings that stem from an independent source such as state law-rules or understandings that secure certain benefits and that support claims of entitlement to those benefits.

Board of Regents v. Roth, 408 U.S. at 577 (emphasis added). In Paul, the Court apparently restricted all property claims, protectable under the fourteenth amendment, to those established by state law. 424 U.S. at $711,712$.

This view is supported by the subsequent decision in Bishop v. Wood, 426 U.S. 341 (1976), where Justice Stevens for a five to four majority held that "the sufficiency of the claim of entitlement must be decided by reference to state law." Id. at 344. The "independent source such as state law" language of Roth had become the more limited total deference suggested by Chief Justice Burger in his concurrence in Roth. 408 U.S. at 603.

This nuance is recognized by Justice Stevens in a footnote, 426 U.S. at $344 \mathrm{n} .7$. In dissent in Bishop, Justice Brennan argued that "[t]here is certainly a federal dimension to the definition of 'property' in the Federal Constitution," id. at 353, citing the above-quoted and italicized language from Roth. In rebuttal, Justice Stevens called Justice Brennan's position "remarkably innovative" 
In Roth, the teacher's contract had expired, he had no legally enforceable claim to reemployment, and therefore the state had no duty to provide a hearing. In the case of competing claimants for scarce life-saving medical resources (Smith), the Roth analysis would require that a "property" interest be shown in some statutory or other obligation imposed on government. Two patients with end-stage renal disease, both eligible for care under the federal kidney treatment program, ${ }^{51}$ might be able to identify such an interest in a federal statute. It is conceivable that state decisions which impose a legal duty on providers of medical care to treat bona fide emergency patients could be construed as a sufficient entitlement in some extreme situations; ${ }^{52}$ typically, however, courts have been willing to dispense with most of the niceties of formal procedure in such circumstances. ${ }^{53}$ Consequently, neither Jones the hemophiliac nor the Smiths, the heart patients, are likely to be able to demonstrate a property interest that warrants protection under due process since there is no "legal guarantee of present enjoyment" 54 of such medical treatment. ${ }^{55}$

and concluded that states may establish or withhold property interests "at their unfettered discretion." Id. at 349 n.14. Justice Stevens apparently holds a more expansive view of "liberty" interests protected by the fourteenth amendment. See Meachum v. Fano, 427 U.S. 215, 229 (1976) (Stevens, J., dissenting), where he argued that a prisoner is entitled to a hearing when transferred from one prison to another. For Justice Stevens, state law "is not the source of liberty, and surely not the exclusive source." Id. That would only be true if a person "were a creature of the State." Id.; see notes 64 and 78 infra and accompanying text.

51. Social Security Act Amendments of 1972, 42 U.S.C. $\$ \S 426(f)-426(\mathrm{~g})(1974)$.

52. See, e.g., Wilmington Gen. Hosp. v. Manlove, 54 Del. 15, 174 A.2d 135 (1961) (a hospital which maintains an emergency service may have legal obligation to admit a patient in an emergency). See also Stanturf v. Sipes, 447 S.W 2d 558 (Mo. 1969). State courts holding a hospital liable for failure to give emergency treatment are apparently still in the minority, however. See Powers, Hospital Emergency Service and the Open Door, 66 Mich. L. Rev. 1455 (1968). Moreover, such an entitlement might still be inadequate to support a due process claim under Paul v. Davis, 424 U.S. 693, 712 (1976). See notes 73-77 infra.

53. See generally Fuentes v. Shevin, 407 U.S. 67, 90-93 (1972); Sniadach v. Family Fin. Corp., 395 U.S. $337,339(1969)$.

54. Paul v. Davis, 424 U.S. at $711-12$.

55. The intensely procedural orientation of the doctrine, as evolved by the Court, must be highlighted. The Court seems to conclude that unless there is an underlying claim of entitlement, a hearing will be a futile gesture since there is no legal standard by which to conduct the hearing. See generally Shirck v. Thomas, 447 F.2d 1025, 1028 (7th Cir. 1971) (Stevens, J., dissenting), rev'd on rehearing, 486 F.2d 691 (7th Cir. 1973) (per Stevens, J.). However, in the allocation of lifesaving medical resources, different considerations might warrant the opposite conclusion-that it is precisely the absence of prior articulated standards that gives the hearing value. If the argument for flexible, unannounced standards, applied by non-accountable bodies such as hospitals, is adopted, see discussion in text infra at section I.B.2., then a hearing will be the forum in which substantive allocative criteria are established. In the course of presenting specific factual evidence, claimants must also seek to establish criteria by which their claims can be evaluated. See Note, Scarce Medical Resources, 69 Colum. L. Rev. 620, 639-65 (1969).

Similarly, a common argument, sometimes ignored by the Court but often made by political scientists and psychologists in support of hearings, may be inappropriate in the context of lifesaving medical resource allocation. See generally J. Thibaut \& L. Walker, Procedural Justice: A Psychological ANalysis (1975). It is argued that a hearing, participatory in nature, has an 


\section{b. The "Liberty" Interest}

The Roth formulation did suggest one other approach. The Court cited previous $\operatorname{cases}^{56}$ dealing with harm to reputation and acknowledged that, where a contract nonrenewal is accompanied by professionally damaging statements, the employee is entitled to a hearing to clear his name. ${ }^{57}$ The Court in Roth identified this interest in reputation as a "liberty" interest subject to procedural protection. ${ }^{58}$ Whereas the "property" interest required explicit statutory or customary expression, the "liberty" interest seemed to allow the Court to give effect to such less specific deprivations, which caused "grievous loss." 59 Subsequently, in Goss v. Lopez, ${ }^{60}$ the Court held that public school pupils were entitled to a hearing ${ }^{61}$ prior to even a ten-day suspension. To be sure, one of the rationales used to justify the conclusion was the legislatively created entitlement in public education. ${ }^{62}$ But quite apart from that "property" interest, the Court, through Justice White, discussed the "liberty" interest in reputation adversely affected by the stigma that attaches to school suspensions. ${ }^{63}$ Due process protection of liberty interests, under Goss and Roth, seemed to require no showing of a nexus between the interest and a state law. ${ }^{64}$

independent value in allowing clarification of fact and providing a mechanism through which disputes can be channeled and hopefully mediated. However, the generalized interests in legitimacy, normally advanced by participation and mediation, may be bought at an excessive price because of the unsettling nature of such allocative hearings. But see Note, Due Process, supra note 17; Katz \& Capron, supra note 17.

56. 408 U.S. 564, 573 (1972), citing Wisconsin v. Constantineau, 400 U.S. 433 (1971); Peters v. Hobby, 349 U.S. 331 (1955); Wieman v. Updegraff, 344 U.S. 183 (1952); Joint Anti-Fascist Refugee Comm. v. McGrath, 341 U.S. 123 (1951); United States v. Lovett, 328 U.S. 303 (1946).

57. 408 U.S. at 573.

58. Id.

59. See Morrissey v. Brewer, 408 U.S. 471,482 (1972). On the question of due process for parole release hearings and an argument that "grievous loss" is an incorrect standard see Comment, Procedural Protection at Parole Release Hearings: The Need for Reform, 1974 DUKE L.J. 1119, 1142 (1974).

60. 419 U.S. 565 (1975).

61. The hearing was to be one which would give the student notice of the charges, and, if he denied them, to give him an explanation of the evidence against him and an opportunity for him to respond. There need be no delay between the commission of the infraction and the affording of this minimal notice and hearing. 419 U.S. at 581-82. The problems of determining the content of a hearing, once it is determined that one is required, are discussed in the text at section I.2. infra.

62. 419 U.S. at 573 .

63. "The Due Process Clause also forbids arbitrary deprivations of liberty .... If sustained and recorded, those charges could seriously damage the students' standing with fellow pupils and their teachers as well as interfere with later opportunities for higher education and employment." Id. at 574-75 (emphasis added). Compare this with Justice Rehnquist's rendering of Goss in Paul v. Davis, 424 U.S. 693, 710 (1976). See also Meachum v. Fano, 427 U.S. 215 (1976) (per White, J.).

64. This was the position Justice Brennan took in Paul v. Davis: "The content of 'liberty' .. has never been thought to depend on recognition of an interest by the State or Federal Government." Paul v. Davis, 424 U.S. at 722-23 n.10; cf. Meachum v. Fano, 427 U.S. 215,229 (Stevens, J., dissenting). See note 50 supra. 
This analytical approach appeared to leave open to the Court a vehicle for imposing procedural safeguards even where "property" interests were not created under state law. By analogy to the treatment of "liberty" interests, the Court could allow itself more flexibility to determine whether those unable to secure scarce life-saving medical resources, and who probably would die as a result, are "deprived" by government of a constitutionally protected interest in "life." 65

Certainly, there are terribly significant consequences for someone denied access to scarce life-saving medical resources-probably death in most cases, since opportunities to shop around will be limited. ${ }^{66}$ The Roth framework seemed to allow examination of the impact of such decisions on interests mentioned in the fourteenth amendment, as in the case of "liberty" interests. Where life and death are in the balance, surely the loss would be sufficiently severe to warrant procedural protection, provided that such was the constitutional test. ${ }^{67}$

The recent decision in Paul v. Davis, ${ }^{68}$ however, makes it questionable whether such an approach is now acceptable to a majority of the Court. Paul involved a claim of state deprivation of an individual's "liberty" interest in reputation. The police circulated a flyer to businessmen identifying by photograph a number of persons "known to be active" in the "criminal field" of shoplifting. ${ }^{69}$ Edward Davis, who had been arrested but never tried or convicted of shoplifting, found his mug shot on the police circular. He claimed that he was entitled to notice and hearing before police could circulate his name and photograph with such damaging effect to his reputation. ${ }^{70}$

In its analysis, the Court appeared to reject the path seemingly left open by $R o t h$ and its progeny. Not only must "property" interests be linked to recogni-

65. See Note, Due Process, supra note 17, at 1741 .

66. R. Campbell, Economics of Health and Public Policy 53-54 (1971); Blumstein \& Zubkoff, Perspectives on Government Policy in the Health Sector, 51 Milbank Memorial Fund Q.: Health AND Soc'y 395, 421-23 (1973).

67. Note, Due Process, supra note 17, at 1741.

68. 424 U.S. 693 (1976).

69. Id. at 695 .

70. The Court's decision in Paul reflects the new majority's skepticism about the increased reliance on federal civil rights suits for vindicating torts claims. Justice Rehnquist seemed critical of plaintiff's failure to pursue a defamation action in state court. Indeed, the procedural posture of Paul highlighted the very federalism concerns that have resulted in curtailment of federal court jurisdiction in a variety of contexts. See, e.g., Younger v. Harris, 401 U.S. 37 (1971); Rizzo v. Goode, 423 U.S. 362 (1976). Plaintiff sought damages for harm to reputation; under the 1871 federal civil rights law, 42 U.S.C. $\$ 1983$, a finding of a constitutional violation is a prerequisite to recovery. Thus, the procedural due process claim came up in a context where institutional reform was not an immediate objective. Of course, the significance of this can be disputed in light of the majority's evident distaste for significant judicial interference with the governance of police practices. See Rizzo v. Goode, supra. See also Aldinger v. Howard, 427 U.S. 1 (1976) (refusal to allow federal court to hear a pendent state claim against a county in a civil rights suit in which the county could not otherwise be joined as a federal defendant). 
tion and protection by state laws, but so must "liberty" interests. ${ }^{71}$ Indeed, a general protection by state tort law of a person's reputation was deemed an insufficient statutory entitlement ${ }^{72}$ to trigger constitutional protection. Speaking for the Court, Justice Rehnquist argued that state law "does not extend to respondent any legal guarantee of present enjoyment of reputation which has been altered as a result of petitioners' [police officials] actions." 73 In the majority's view, the state provided a forum for vindicating (by damages) harm to an individual's reputation. ${ }^{74}$ The tort-law protection, however, did not create a claim of entitlement against the state; government was serving as mediator between private parties, establishing entitlements as between them only.

In the Court's view, this legally created protection against defamation places the government in the role of an umpire, establishing ground rules by which to resolve those private disputes. ${ }^{75}$ Even when one of the "private" parties is the state itself (or an officer acting under color of law), the Court is unwilling to recognize the ensuing harm to reputation as a deprivation of "liberty" since it has not "worked any change of.. . status as theretofore recognized under the State's laws." "76 Since no "right vouchsafed . . . by the State" 77 to Davis was implicated, Justice Rehnquist found no procedural protection under due process necessary.

While it is too soon to know what effect Paul will have in future cases, ${ }^{78}$ its

71. See Paul v. Davis, 424 U.S. at 710-12; of. Meachum v. Fano, 427 U.S. 215 (1976)

72. For a different view of "entitlement," see Calabresi \& Melamed. Property Rules, Liability Rules, and Inalienability: One View of the Cathedral, 85 HARv. L. REv. 1089 (1972).

73. 424 U.S. at $711-12$.

74. Id. See also Meachum v. Fano, 427 U.S. 215 (1976); Scott v. Kentucky Parole Board, 429 U.S. 60 (1976) (per curiam).

75. For a discussion of the effect of different governmental roles in the context of determining when a "taking" of private property occurs, see Sax, Takings, Private Property, and Public Rights, 81 Yale L.J. 149 (1971); Sax, Takings and the Police Power, 74 Yale L.J. 36 (1964).

76. Paul v. Davis, 424 U.S. at 712.

77. $I d$.

78. Justice Brennan noted in dissent: "Today's decision must surely be a short-lived aberration." Id. at 735. He also has said that it is "overtly hostile" to "basic constitutional safeguards." Bishop v. Wood, 426 U.S. 341, 351 (1976) (Brennan, J., dissenting).

There is some indication that the apparent restriction of "liberty" interests to statutorily conferred entitlements and to the Bill of Rights, see note 79 infra, has been modified by at least two subsequent decisions. In Ingraham v. Wright, 97 S. C. 1401 (1977), the majority (per Powell, J.) conceded that corporal punishment (paddling) of schoolchildren implicated a constitutionally protected liberty interest. The Court acknowledged that no "state-created interest in liberty," $97 \mathrm{~S}$. Ct. at 1414 n.43, was at stake; rather, the Court found that the fourteenth amendment itself was the source of a person's interest in being free from "unjustified intrusions on personal security." $I d$, at 1413. Thus, the Court held that a schoolchild's liberty interests were sufficiently implicated to trigger procedural due process guarantees because the fourteenth amendment's protection extended to "freedom from bodily restraint and corporal punishment." Id. at 1414 n.43.

In Smith v. Organization of Foster Families for Equality and Reform, 45 U.S.L.W. 4638 (U.S. June 13, 1977), foster parents alleged they had sufficient liberty interests in retaining custody over foster children to require an elaborate hearing prior to state removal of the children. As in 
analytical framework surely must be deemed to reflect the present view of a majority of the Court. This means that, in the absence of legislatively ${ }^{79}$ created entitlements as against government itself, the Court will not impose procedural safeguards under due process, "however seriously" ${ }^{\circ 0}$ the interests of an individual may be harmed. ${ }^{81}$

Ingraham, the Court's narrow holding in Smith was that the state procedures satisfied due process standards. See also Matthews v. Eldridge, 424 U.S. 319, 334-35 (1976). However, the majority opinion in Smith (per Brennan, J.) discussed the liberty issue at length prior to assuming the presence of a constitutionally protected interest. It initially rejected the "grievous loss" standard on the authority of Meachum v. Fano, 427 U.S. 215 (1976). The nature of the interest at stake, not the magnitude of the harm, is the test. See Board of Regents v. Roth, 408 U.S. 564, 570-71 (1972). Nevertheless, in proceeding to discuss the foster parents alleged liberty interests, the Court acknowledged that the fourteenth amendment of itself protects a private realm of family life: and this interest has received both substantive and procedural protection, 45 U.S.L.W. at 4645. The majority opinion explicitly stated that, unlike property interests, the liberty interest in family privacy "has its source, and its contours are ordinarily to be sought, not in state law, but in intrinsic human rights. ..."Id.

The decisions in Ingraham and Smith may reflect a retreat from some of the more extreme implications of Paul v. Davis, 424 U.S. 693 (1976). At least they may signal the willingness of the Court, in a limited class of cases, to look at the fourteenth amendment itself, as well as state law and the Bill of Rights, as a source of a constitutionally protected liberty claim. It is still uncertain whether the Court would recognize a liberty interest in the context of allocating governmental resources to the provision of scarce life-saving medical resources.

79. In Paul, Justice Rehnquist acknowledged that the Bill of Rights can serve as a source of entitlements that can support a claim for procedural due process protection. 424 U.S. at 710 n.5. This position seems to run counter to at least part of Roth where the Court specifically rejected Roth's claim to a hearing, which was in part based on his allegation that his contract was not renewed because of constitutionally protected statements he made; the only remedy under Roth for vindicating the teacher's first amendment interests was an action in the courts, not a hearing before appropriate university officials. See Board of Regents v. Roth, 408 U.S. 564, 575 n. 14 (1972). Justice Stewart took pains to argue in Roth that first amendment values, as such, were not there implicated-only employment interests. But the constitutional violation, Justice Stewart conceded, would be an infringement of first amendment rights. See Perry v. Sindermann, 408 U.S. 593 (1972). One way to reconcile the argument in Roth and Sindermann with the footnote in Paul is to perceive the constitutional violation alleged in Roth and Sindermann as a prohibited penalty on the exercise of the fundamental interest in expression. Such a classification principle would trigger strict scrutiny under equal protection. See note 316 infra. See generally Dunn v. Blumstein, 405 U.S. 330 (1972); Shapiro v. Thompson, 394 U.S. 618 (1969); Williams v. Rhodes, 393 U.S. 23 (1968); Sherbert v. Verner, 374 U.S. 398 (1963).

80. Paul v. Davis, 424 U.S. at 712 .

81. This position would undermine much earlier analysis. See, e.g., Note, Due Process, supra note 17, at 1139-41. The decisions sustaining state refusal to pay for nontherapeutic abortions are instructive, Maher v. Roe, 45 U.S.L.W. 4787 (U.S. June 20, 1977), Poelker v. Doe, 45 U.S.L.W. 4794 (U.S. June 20, 1977). The Court earlier had held that a state could not interfere with a woman's right to terminate a pregnancy, at least prior to the fetus's viability. Roe $v$. Wade, 410 U.S. 113 (1973). Planned Parenthood of Cent. Missouri v. Danforth. 428 U.S. 52 (1976). In Maher, the Court made it clear that the state has no obligation to pay for any medical expenses of indigents, 45 U.S.L.W. at 4789 . A state does not deprive a woman of her liberty interest in choosing whether to bear a child because it refuses to pay for an abortion. The state is not depriving a woman of any liberty interest, under the reasoning in Maher, because it places no regulatory obstacles in her path. The state's decision to fund childbirth places the pregnant indigent in no disadvantageous position on that account alone. According to Justice Powell, "[T]he indigency that may make it difficult-and in some cases, perhaps, impossible-for some women to have abortions is neither created nor in any way affected by" the decision not to pay for abortions. 45 U.S.L.W. at 4790 . By analogy, a claimant may have no liberty interest infringed by 


\section{c. The "Life" Interest}

The Paul opinion was limited to analysis of "liberty" or "property" interests. Arguably, claimants for scarce life-saving medical resources could tie their interest in "life" more closely to the text of the fourteenth amendment than can a person whose reputation has been harmed. But in a preliminary discourse about the undesirability of applying the fourteenth amendment against "every legally cognizable injury which may have been inflicted by a state official acting under "color of law," "82 Justice Rehnquist used the example of a suit by survivors of an innocent bystander "mistakenly shot by a policeman or negligently killed by a sheriff driving a government vehicle." 83 Justice Rehnquist acknowledged that such an event could arguably involve a governmental deprivation of "life," presumably an interest protected against state deprivation by the fourteenth amendment; yet for Justice Rehnquist the interests protected by the fourteenth amendment must be recognized and established by state law (or by the Bill of Rights when incorporated into the fourteenth amendment $)^{84}$ in order to receive procedural safeguards of due process. $^{85}$

Thus, in the life-saving medical resources context, absent a statutory or customary duty, it is distinctly unlikely that the Court would, as a constitutional matter, expand government's responsibility for the maintenance and sustenance of life. Such expansive readings of the concepts of "life" and "deprivation" under the fourteenth amendment would transform the nature of government's role in the life-saving area, thrusting on the state the "role of a giver of life itself." 86 The Court appears unwilling to read into the Constitution such positivistic notions, ${ }^{87}$ and that analytical approach would be out of step with recent decisions. ${ }^{88}$

government's refusal to provide scarce medical resources since the state is not depriving the patient of a right he has against the government. See Paul v. Davis, 424 U.S. at 712 . Unless a prior duty on the part of government can be identified, Maher would seem to question whether a "deprivation" of a liberty interest can be made out by a state's refusal to fund treatment, even if it be assumed that a liberty interest protected by the fourteenth amendment is found (see note 78 supra).

82. 424 U.S. at 699

83. Id. at 698 .

84. Id. at 710 n.5.

85. See notes 78,79, \& 81 supra.

86. Ethics of Health Care, supra note 13, at 31. In addition, such an expanded, open-ended role for government would have very significant policy implications because of the symbolic values that become implicated when life is perceived to be in the balance. The pecuniary costs that may be deemed necessary could be very high and yet still paid, not so much to preserve a single life as not to sacrifice openly an important myth-that life is beyond price. See Zeckhauser, Catastrophic Illness, supra note 7; Zeckhauser, Valuing Lites, supra note 7.

87. See United States v. MacCollom, 426 U.S. 317 (1976); San Antonio Independent School Dist. v. Rodriguez, 411 U.S. 1 (1973); Dandridge v. Williams, 397 U.S. 471 (1970).

88. E.g., Maher v. Roe, 45 U.S.L.W. 4787 (U.S. June 20, 1977); Bishop v. Wood, 426 U.S. 341,349 n.14 (1976); Paul v. Davis, 424 U.S. 693 (1976). But see Smith v. Organization of Foster 


\section{B. Adoption of Formal Standards}

\section{Generally}

If the threshold issues-state action, "deprivation" of a protected interest-are resolved, a question arises whether a decision maker must establish and publish formal policies or rules. ${ }^{89}$ Notions of accountability and restraints on arbitrariness often spur the movement toward rulemaking as a means of limiting discretionary authority. ${ }^{90}$ Thus, applicants for public housing ${ }^{1}$ may seek to compel a housing agency to establish and publish criteria by which to guide their own decision making and by which prospective applicants can tell where they stand and why. ${ }^{92}$ The criticism of administrative bodies which rely primarily on adjudication rather than a mix of rulemaking and adjudication is based on the same concern for the unrestrained-and therefore potentially arbitrary-exercise of power. ${ }^{93}$

The countervailing concern, cutting against adoption of formal rules to guide decision making in great detail, is the problem of legislative foresight and lack of flexibility. Thus, in McGautha $v$. California ${ }^{94}$ the Supreme Court rejected a claim that standardless sentencing procedures in capital cases violated due process because of the majority's view that the legislature was incapable of refining its rules sufficiently to deal with the multiplicity of factors involved in deciding on capital punishment. ${ }^{95}$ Ironically, the following year the Court seemed to say that the flexible system itself, because it resulted in unprincipled and sometimes arbitrary outcomes, constituted "cruel and unusual punishment." ${ }^{96}$ This tension between rules and certainty on the one

Families for Equality and Reform, 45 U.S.L.W. 4638 (U.S. June 13, 1977); Ingraham v. Wright, 97 S. Ct. 1401 (1977).

89. See Note, Due Process, supra note 17, at 1741; Note, Scarce Medical Resources, 69 Colum. L. Rev. 620 (1969); cf. Holmes v. New York City Housing Authority, 398 F.2d 262 (2d Cir. 1968) (requiring tenant selection criteria for public housing); Hornsby v. Allen, 326 F.2d 605 (5th Cir. 1964) (requiring standards for the allocation of liquor licenses).

90. See generally K. Davis, Discretionary Justice (1969). See also Katz \& Capron, supra note 17.

91. Holmes v. New York City Housing Authority, 398 F.2d 262.

92. Similarly, property owners may seek to limit rezoning by restricting legislative authority through imposition and adoption of formal planning principles with which zone changes must be consistent. See, e.g., Fasano v. Board of County Comm'rs, 507 P.2d 23 (Ore. 1973). But see City of Eastlake v. Forest City Enterprises, 426 U.S. 668 (1976).

93. Reich, The Law of the Planned Society, 75 Yale L.J. 1227 (1966); see Reich, The New Property, 73 YALE L.J. 733 (1964).

94. 402 U.S. 183 (1971).

95. For an eloquent statement of the vices of overly vague sentencing standards, see Justice Brennan's dissenting opinion, id. at 248.

96. U.S. Const. amend. VIII; Furman v. Georgia, 408 U.S. 258 (1972).

The juxtaposition of Furman and McGautha is of considerable interest. Prior to McGautha, the Court had invalidated a jury selection procedure that had the effect of eliminating from juries those opposed to capital punishment. Witherspoon v. Illinois, 391 U.S. 510 (1968). The focus of the Court's decision was on improving the representativeness of the jury since it was empowered 
hand and individualized ad hoc decision making and ambiguity on the other is not easily resolved. The benefits of objectivity and limits on arbitrariness are counterbalanced by the flexibility, possible precision, and compassion of the ad hoc system of individualized decision making. ${ }^{97}$

As a constitutional matter, where the Court has worried about the impact of administrative discretion on fundamental freedoms, (e.g., licensing involving free speech questions), ${ }^{98}$ the requirement has been to minimize flexibility for the very purpose of eliminating individualized differentiation. ${ }^{99}$ Thus, the Court is likely in such cases to allow only ministerial duties to be performed by administrative officials. "10 The standards must be "narrow, objective, and definite." ${ }^{101}$ Similarly, the capital punishment cases ${ }^{102}$ appear to require a definite, politically accountable, legislative definition of crimes subject to capital punishment, without significant jury discretion-a task evidently thought virtually impossible in McGautha. ${ }^{103}$

with such a terrific amount of discretion. If such a lay and unaccountable body were to exercise this authority, it must be broadly representative in its composition.

In McGautha, the majority upheld the process by which capital punishment decisions were made, refusing to hold that standardless sentencing procedures violated due process. Largely because the Court believed that no adequate standards could be formulated in advance by the politically accountable legislature, it rejected the due process challenge.

The multiple decisions in Furman meant that there was no majority holding. What the dissenters called the "pivotal" opinions (by Justices Stewart and White) emphasized the unpredictable-even "freakish"-pattern by which capital decisions were rendered. While the process by which the decisions were rendered was not unconstitutionally faulty, it seems, the Court was unwilling to accept the outcomes that at least several of the justices believed to be impermissibly arbitrary (and therefore "cruel and unusual punishment" under the eighth amendment). See also C. Black, Capital Punishment: The Inevitability of Caprice and Mistake (1974).

The Court's response, in its most recent decisions, has been to return its attention to the formulation of standards by politically accountable officials. Where state legislatures have established detailed criteria for imposition of the death penalty, the Court has sustained capital punishment. See cases cited in note 124 infra.

It must be conceded that the outcome-oriented safeguard does not exist as readily in the lifesaving medical resources area simply because the time horizon is so telescoped. The multiple stages of trial, appeal, and post-conviction relief extend the process sufficiently to ascertain an outcome pattern before a life is taken. Patients unable to secure life-saving treatment may perish before examination of results is possible. Of course, capital punishment and unavailability of life-saving treatment pose different problems, and the cruel and unusual punishment rubric may in any case be inapplicable. See, e.g., Ingraham v. Wright, 97 S. Ct. 1401, 1412 (1977).

97. The middle ground of articulating principles instead of "rules" is an attempt to compromise between the two models, capturing the best of both. See Dworkin, The Model of Rules, 35 U. Chi. L. Rev. 14 (1967); Tribe, Structural Due Process, 10 Harv. Giv. Rights-Civ. Lib. L. Rev. 269 (1975)

98. Freedman v. Maryland, 380 U.S. 51 (1965); Kunz v. New York, 340 U.S. 290 (1951).

99. See, e.g., Shuttlesworth v. Birmingham, 394 U.S. 147 (1969).

100. See generally Shuttlesworth v. Birmingham, 394 U.S. 147: Kunz v. New York, 340 U.S 290.

101. Shuttlesworth v. Birmingham, 394 U.S. at 151

102. Furman v. Georgia, 408 U.S. 238, 397 (1972) (Burger, C.I., dissenting); Roberts v. Louisiana, 428 U.S. 325 (1976); Woodson v. North Carolina, 428 U.S. 280 (1976). See also Proffitt v. Florida, 428 U.S. 242 (1976); Jurek v. Texas, 428 U.S. 262 (1976); Gregg v. Georgia, 428 U.S. 153 (1976).

103. See discussion of McGautha, supra note 96. Many state legislatures responded to Furman 


\section{Articulation of Allocative Criteria}

Whether a court should impose a duty on public decision makers to establish and publish criteria-either rules or principles-to govern allocation of scarce life-saving medical resources is problematic. While the desirability of reducing arbitrariness is undeniable, the problems posed by such clearly formulated criteria are themselves rather substantial. There is the difficulty of formulating standards, foreseeing the variety of problems and nuances that inevitably will arise. More importantly, there is the spectacle of government (under judicial mandate, no less) openly renouncing the widely held belief in the sanctity of human life, acknowledging for all to see that society is unwilling to expend the funds necessary to obviate the scarcity that causes the allocative problem. ${ }^{104}$ Formulation of official priorities will likely have a debilitating effect on long-held symbolic values, especially since decisions will often affect clearly identifiable individuals. ${ }^{105}$

Professor Guido Calabresi has been a prominent commentator on the problems that society inevitably faces in making these "tragic choices," that is, "situations where there is no right decision."106 Because of the many conflicting values prevalent in a pluralistic, democratic nation, it becomes impossible, notes Calabresi, to satisfy all such values in resolving tragic choices. He points to two facets of the problem, both relating to external costs and benefits associated with government's valuing of human life. First, though society may value x's life more than y's, for whatever reason, "any explicit recognition that the saint's life is worth more than a scoundrel's is, and should be, exceedingly

by enacting "no-mercy statutes." The scope of discretion was narrowed by eliminating flexibility, not by establishing more precise standards for exercising discretion. The Court invalidated those laws. See note 325 infra.

104. Medical students are openly taught principles of triage. In the context of warfare, military worth is the overriding factor; but our society has learned to make normative allowances in military situations. In emergency room decision making, scarcity is accommodated on allegedly medical criteria. It is indeed notable that principles of triage vary so significantly in the warfare and civilian contexts. The language of medical practice shields the trenchant value choices that necessarily underlie triage principles even in the civilian arena.

The importance of perception is well illustrated by testimony offered in the Quinlan case. Dr. Sidney Diamond observed that it would be inappropriate to turn off Karen's respirator since she was "alive" by accepted medical definitions. On the other hand, Dr. Diamond found it "incredible" that "any physicians would respond to a sudden hemorrhage . . . by giving her large quantities of blood ... even if they were known to be essential for continued physical existence." In In re Quinlan, 70 N.J. 10, 28-29, 355 A.2d 647, 657 (1976) the New Jersey Supreme Court had trouble seeing the distinction, but it seems the medical profession has learned to live with the life-saving imperative by conserving only scarce supplies while not recognizing more general resource limitations. See generally Havighurst \& Blumstein, supra note 1, at 25-30. In this context it is interesting that in neither the trial court nor in the Supreme Court opinion in Quinlan were costs mentioned as a prominent factor.

105. See G. Calabresi, Tragic Choices, supra note 13; Blumstein \& Zubkoff, supra note 12. The impact is recognized even by those who disagree with the conclusions reached in this article. See, e.g., Katz \& CaPron, supra note 17, at 3; Note, Due Process, supra note 17, at 1746.

106. Calabresi, Commentary, supra note 13, at 53-54. 
costly in an egalitarian society." 107 Secondly, Calabresi notes that the process by which lives are valued may itself involve external costs. He poignantly relates the problem posed by Justice Stewart during oral argument of the Pentagon Papers case. ${ }^{108}$ Concerned about the impact or outcome of a decision that permitted publication of a report which revealed critical military secrets, Justice Stewart asked what would happen if publication meant "a judicial sentencing to death of a hundred people." ${ }^{109}$ From that repartee, Calabresi observes that "there are harms . . . that depend on the process used to decide terribly important issues like life or death," 110 and concludes that a strategic objective should be to create institutions that avoid allowing an issue to be framed in such a way. ${ }^{111}$

The traditional legal approach emphasizes formulation of explicit criteria as a means of limiting abuse of discretion. This is reflected in proposals that would even eliminate all ad hoc decision making because it "might invite abuse"112 and in frank lawyerly preferences for "open, 'visible' decisionmaking." 113 Yet Calabresi is surely correct in his argument that at present (and perhaps inevitably) no available choice mechanism is totally satisfactory and that "when one is talking about governmental decisionmaking and the preciousness of life, one has to concentrate on external effects and on different procedures that, while they don't avoid, at least minimize the external effects."114 Minimizing harm may necessarily mean, in a society of inconsistent fundamental values, a shifting back and forth from one system to another, seeking to pursue all societal goals simultaneously though implicitly acknowledging failure to adhere to some for a period. ${ }^{115}$

The call for articulation of allocation standards also represents the view that political accountability and visibility are antidotes to unfairness and to potential or submerged discrimination against "those groups within society who are traditionally the objects of neglect and mistreatment." 116 But, unless nonsubstantive devices such as a lottery are used, (i.e., the choice not to choose), ${ }^{117}$ it is clear that some expressly unegalitarian values will appear in official allocative criteria, and the unegalitarian choice will be made harder to accept because of the very fact of its legitimation through the political pro-

107. Id. at 52.

108. New York Times Co. v. United States, 403 U.S. 713 (1971).

109. Calabresi, Commentary, supra note 13, at 53.

110. Id.

$111 . I d$

112. See Note, Due Process, supra note 17, at 1747 n.61: "Admittedly, to allow any discretion at all might invite abuse, and perhaps no ad hoc 'solutions' should be allowed."

113. KaTz \& CAPRon, supra note 17 , at 3.

114. Calabresi, Commentary, supra note 13 , at 54.

115. See G. Calabresi, Tragic Choices, supra note 13. See also Zeckhauser, Catastrophic Illness, supra note 7 , at $170-71$ n.37.

116. Katz \& CaPRon, supra note 17 , at 3.

117. See G. Calabresi, Tragic Choices, supra note 13. 
cess (and possible imposition as a duty by the courts). It represents a politically sanctioned consensus that some people will be favored over others because of certain overtly articulated factors. The decision cannot be blamed on an impersonal, decentralized market process, but rather the government becomes the party directly responsible, having made an express political choice $^{118}$ and a clear statement that some lives are just not worth the cost of saving. This constitutes a significant breach of a societal myth that is deservedly cherished as an abstract principle. ${ }^{119}$

This discussion, then, questions the wisdom of requiring express articulation of rules or principles of decision because whatever choice is made inevitably is a "bad" choice-destructive of importantly held values. ${ }^{120}$ For a court to make this type of choice raises serious institutional concerns, especially since the format of decision making itself has such significant policy consequences. ${ }^{121}$ The terribly difficult issues the Court has grappled with in the capital punishment cases certainly provide insight into the kinds of problems awaiting courts in resolving cases which involve allocation of scarce lifesaving medical resources. The more visible and more directly accountable the government becomes, the more nearly analogous to capital punishment decisions these issues become. ${ }^{122}$ The possible result would be a subtle form of institutional blackmail, inducing society to spend more resources in this area than it might otherwise choose. ${ }^{123}$

In determining whether to impose capital punishment, government is re-

118. An example of this phenomenon is the problem that democratic governments have in combating inflation or curtailing social welfare spending. While unemployment may be a necessary evil when the result of uncontrollable market forces, it is unacceptable inhumanity when adopted as an explicit antidote to spiraling price levels. See generally Marmor, Wittman, \& Heagy, The Politics of Medical Inflation, $1 \mathrm{~J}$. of Healty Politics, Policy \& Law 69 (1976).

119. See generally Zeckhauser, Catastrophic Illness, supra note 7; Zeckhauser, Valuing Lives, supra note 7 .

120. See Sanders \& Dukeminier, Medical Advance and Legal Lag: Hemodialysis and Kidney Transplantation, 15 U.C.L.A. L. REv. 357, 366-80 (1968), discussing the problems of choosing criteria; Note, Scarce Medical Resources, 69 Colum. L. REv. 620, 639-65 (1969); cf. Furman v. Georgia, 408 U.S. 238, 314, 360-69 (1972) (opinion of Marshall, J.).

121. See Zeckhauser, Valuing Lives, supra note 7.

122. An analogous situation will help illuminate the importance of context in life and death decisions. Capital punishment is widely condemned, in part because of the unavoidable identification of government with the imposition of death. There is no camouflaging the purpose or the collectively conscious decision to kill a human being. Accident or incidental effect is not a plausible explanation. While execution may be deemed an inappropriate punishment, that does not stop a broad consensus from condoning use of deadly force in capturing a fleeing felon. Even where the police officer's life is not directly threatened he may generally use deadly force in such situations. See, e.g., Stinnett v. Virginia, 55 F.2d 644, 645 (4th Cir. 1932). Civil libertarians may find this rule unacceptable, but it is clear that the objections have nowhere near the same force as in capital punishment. Part of the reason would appear to be the lesser degree of formal official approval involved, the lower visibility, and the existence of explanations such as accident or unfortunate side-effect of aggressive law enforcement.

123. Havighurst \& Blumstein, supra note 1, at 6-7 n.1, 15-20 n.36; Blumstein, supra note 1, at $272-73$ 
quired to face the hard life and death questions directly, and the Court will not permit government to make the choice for death lightly, and will severely limit the discretion to choose life or death. ${ }^{124}$ Yet, in "tragic choice" situations, what Calabresi calls "a-responsible agencies" may serve a valuable function. ${ }^{25}$ Ad hoc standardless decisions, like those of juries or hospital committees, for example, have an idiosyncratic character which submerges the weight being assigned to different variables and blurs the hierarchy of values chosen. Decisions are made informally, ${ }^{126}$ and the criteria are not specifically articulated, mitigating the "devastating impact" of the "complex and hard choices" 127 that are implicitly made. ${ }^{128}$

It would therefore seem imprudent for a court to impose, as a constitutional mandate, the necessity for establishing articulated rules or principles to govern micro decisions on allocating scarce life-saving medical resources. The late Professor Alexander Bickel was fond of noting the "tension between principle and expediency"129 in a democratic system of government: "No good society can be unprincipled; and no viable society can be principleridden." ${ }^{30}$ This sounds like wise advice on the question of imposing a constitutional duty to articulate allocative criteria.

124. Roberts v. Louisiana, 428 U.S. 325 (1976); Woodson v. North Carolina, 428 U.S. 280 (1976); Proffitt v. Florida, 428 U.S. 242 (1976); Jurek v. Texas, 428 U.S. 262 (1976); Gregg v. Georgia, 428 U.S. 153 (1976).

125. G. Calabresi, Tragic Choices, supra note 13.

126. Cf. Crane, supra note 10; Hollingshead, Medical Sociology: A Brief Review, 51 MiLbank Memorial Fund Q: Health \& Soc'y 531 (1973).

127. KATZ \& CAPRON, supra note 17 , at 3 .

128. It is clear that, in the absence of clear standards, micro decision makers (usually physicians) must make allocative choices for scarce life-saving medical resources. One study has found, not surprisingly, that physicians look at non-medical as well as medical factors in their decisions whether to treat critically ill patients. See Crane, supra note 10. Thus, doctors will determine a patient's ability to interact with others and his "salvageability," or ability to reassume social roles. But informal practice and the traditional medical ethic are at variance: "According to the traditional ethic, treatment is meant to be continued as long as life, defined in physiological terms, can be preserved. In fact ... treatment is generally withdrawn when the quality of life as defined in social terms has deteriorated or disappeared irrevocably." Id. at 29.

One resolution is to attempt to alter formal norms by redefining basic notions, such as death, if a new consensus of values has sufficiently coalesced. The label "death" allows us to submerge the value choices inherent in adopting certain behavior. Thus, in Quinlan. the commonly accepted definitions of death, adopted with different situations in mind (e.g., organ transplantation), did not apply. In In re Quinlan, 137 N.J. Super. 227, 243, 348 A.2d 801, 810 (1975), when Karen's plight received national attention, the conflict between medical ethic and informal practice became acute. Informal practice could not prevail in the glare of such publicity. Under the very same physiological conditions, however, the attending physician could have felt comfortable, and not subject to criticism, had he unplugged the respirator-provided that a consensus could agree that Karen was "dead" in that context. This shows that once hard cases become visible-and no conveniently defusing labels such as "death" are applicable-there are external costs of medical decision making. See Havighurst, Blumstein \& Bovbjerg, supra note 33.

129. A Bickel, The Least Dangerous Branch: The Supreme Cour:- at the Bar of Politics 68 (1962).

130. See Bickel, The Supreme Court, 1960 Term-Foreword: The Passive Virtues, 75 HARv. L. REv. $40,49(1961)$. 


\section{Contents of Hearing}

While the Court will routinely require notice and hearing as basic elements of procedural due process, it has indicated that the format and scope of the hearing must reflect a balancing of competing societal concerns in which cost factors, both pecuniary and nonpecuniary, will be considered. ${ }^{131}$

\section{Scope}

In situations such as that represented by the Smith twins, where a hearing would determine the relative merits of competing claimants for scarce medical resources, hearing officers and decision makers should have their authority clearly confined to the micro allocation choice. ${ }^{132}$ There are two reasons for this. First, there is the risk that if macro reallocation ${ }^{\mathbf{1 3 3}}$ is an option, then the incentives to consider resource limitations would disappear. Allocative constraints, necessitated by macro allocation decisions, can only be respected if the adjudicatory bodies have their authority limited to choosing beneficiaries for utilization of scarce medical resources. Otherwise, the identifiable lives involved in the hearing could all too easily implicate modifications in the macro decision, ${ }^{\mathbf{1 3 4}}$ thereby avoiding the hard choices necessitated by resource scarcity.

Second, the spectacle of a governmentally sponsored hearing for one's life must adversely affect basic societal values, if only at the symbolic level. However, the adverse effect is somewhat reduced if the power of the hearing board is widely known to be limited. Unlike a court, which faces pressures to order improved services because it has the power implicitly to mandate resource reallocation, ${ }^{\mathbf{1 3 5}}$ a hearing body can avoid some of the external harm

131. See Mathews v. Eldridge, 424 U.S. 319 (1976); Gagnon v. Scarpelli, 411 U.S. 778 (1973); Morrissey v. Brewer, 408 U.S. 471 (1972).

132. Where the resource is unique (as with a heart for transplant), macro reallocation (see note 133 infra) is not generally feasible since the resource is fixed. However, if the Smith situation is slightly modified, to envision implantation of an artificial heart, the macro reallocation problem becomes more apparent since more artificial hearts can, presumably, be produced if funds are made available.

133. Macro allocation decisions determine the size of the budget for a particular governmental activity. Micro allocation decisions refer to the case by case determination of eligibility for the distribution of those funds in the course of that governmental activity.

134. The tension between micro and macro level approaches is succinctly stated by Carl Stevens: "Decisions which seem economically necessary and ethically appropriate at the first [macro-prospective] level force choices at the second [micro-immediate] level which seem ethically unacceptable (and vice-versa-aggregating up from the micro-immediate level in response to ethical imperatives seems to result in a requirement at the macro-prospective level which is economically unacceptable)." See Zeckhauser, Catastrophic Illness, supra note 7, at 163 n.24.

135. Having the power but not the responsibility to reallocate resources, the courts can devise remedies which have significant financial consequences without considering where the money is coming from. Thus in Brewer v. School Board of City of Norfolk, 456 F.2d 943 (4th Cir. 1972), the court found no difficulty in ordering the expenditure of three million dollars to provide transportation for students under a court-ordered busing scheme. See Milliken v. Bradley, 45 U.S.L.W. 4873 (U.S. June 27,1977 ). 
because of its limited power. In this way, since the available options are so restricted, the triage analogy becomes more apparent and compelling-tragic choices must be made, not avoided. And the external harm of such decisions may be minimized if the popular view is maintained that no other option existed but to make a difficult, though necessary, choice. ${ }^{136}$

\section{Procedural Components}

In institutional settings, the Court has been sensitive to tailor the procedures required by due process to the specific needs of the institution. ${ }^{137}$ The hearing should allow competing claimants to present evidence, both of a factual nature and relating to substantive criteria to be applied. ${ }^{138}$ Implicitly, such a hearing would have elements of rulemaking ${ }^{139}$ and of the comparative hearing ${ }^{140}$ employed by administrative agencies to determine which of several applicants gets a TV channel, an airline route, and so on.

The extended discussion on the requirement for articulated criteria is relevant on the question whether a record should be maintained and an opinion written. A record allows for some review of the proceedings and might help conscientious panels seeking to achieve consistency. Moreover, it is clear that some forms of abuses will be so clearly intolerable (e.g., race classification) that a record should be kept to allow proof of such a discriminatory pattern or practice. Whether a record, if kept, should be publicly available is doubtful, and the requirement of a written opinion could diminish or eliminate the value of the "a-responsible" agency model.

The interest in openness, visibility, and public awareness might promote

\footnotetext{
Similarly, Professional Standards Review Organizations (PSROs) having no budgetary responsibilities can review the "necessity" of medical outlays without regard to the financial consequences of their actions. Unencumbered by having to live within a pre-determined budget, and unable to capture any savings that would accrue from a rigorous balancing of costs and benefits, PSROs, like courts, have similar institutional incentives to succumb to a professionally determined standard of need. See Blumstein, supra note 1, at 283-85; Havighurst \& Blumstein, supra note 1, at $27-28,50,66$.

136. The text considers the scope of jurisdiction where competing claimants are being heard. By its nature, that situation can require decision makers to cope with scarcity, albeit uncomfortably. Where hearings are held on the more general question of eligibility, the device of limiting jurisdiction to micro decision making is insufficient. Indeed, PSROs currently are structured in this way but need not face resource constraints since those whose care they approve are funded through the federal fisc. In such situations, it might be desirable for hearing boards to have broader program responsibility, or a fixed budget, so that resource constraints enter into their decision-making process. See generally Havighurst \& Blumstein, supra note 1 . See also note 55 supra.

137. See, e.g., Goss v. Lopez, 419 U.S. 565 (1975); Wolff v. McDonnell, 418 U.S. 539 (1974).

138. See note 55 supra; $f f$. Tribe, Structural Due Process, 10 Harv. Civ. Rights-Civ. Lib. L. Rev. 269, $281-83$ (1975).

139. K. Davis, Administrative Law $\$$ 2.00-.06 (Supp. 1970).

140. E.g., Federal Communications Act, 47 U.S.C. $\$ 309(\mathrm{a})$ (1970), construed in Ashbacker Radio Corp. v. FCC, 326 U.S. 327 (1945).
} 
the kind of debate its proponents say it would; ${ }^{141}$ a decision by a board (like that of a jury), without opinion, does give the misleading impression of a fact determination based on some value standard when the decision actually turns in large part on very delicate value choices. ${ }^{142}$ But the costs of such opinions, which (with government sanction) might assign priorities based on value-tosociety characteristics, would be substantial. Given the time, actual cost, potential external cost of visibility, and the dubiety of the articulated benefits, it seems inappropriate to require, as a constitutional matter, the preparation and circulation of an opinion. ${ }^{143}$

II

\section{The Role of Courts in Resource Allocation}

Constitutional claims for procedural protection, as discussed in the previous section, can have a significant impact on the substantive resource allocation decisions that society makes, and can require outlays for establishing appropriate procedures. ${ }^{144}$ But courts assume a more direct role in the resource allocation process when presented with substantive constitutional claims-(1) that government has an affirmative duty to provide access to life-saving medical resources; and (2) that, where provided to some, government must provide such services to others.

The courts have not been unaware of the fiscal impact of judicial decisions $\mathbf{1 4 5}^{\mathbf{4 5}}$ that either impose affirmative duties on 'government or invalidate

141. See Note, Due Process, supra note 17, at 1742-44.

142. Cf. MCCoy, Logic vs. Value Judgment in Legal and Ethical Thought, 23 VAND. L. REv. 1277 (1970).

143. For a discussion of other procedural components, see Note, Due Process, supra note 17. See generally Goss v. Lopez, 419 U.S. 565 (1975); Wolff v. McDonnell, 418 U.S. 539 (1974); Goldberg v. Kelly, 397 U.S. 254 (1970).

144. See Mathews v. Lucas, 427 U.S. 495 (1976); Weinberger v. Salfi, 422 U.S. 749 (1975).

145. See, e.g., Rhem v. Malcolm, 507 F.2d 333 (2d Cir. 1974). Judicial reluctance to intervene actively in formulating substantive principles that have financial consequences is reflected also in the case law evolving from such programs as environmental protection and occupational safety. Decisions about environmental impact or job-site safety requirements implicitly involve judgments on values of human life. Through administrative rule making, government is required to balance competing considerations of economic cost and human health and safety. The courts seem to review rigorously the procedures by which government formulates its standards but generally refrain from substituting substantive judicial values for those chosen by the regulatory agency. This approach is marked in judicial construction of the requirement to prepare environmental impact statements. See Calvert Cliff' Coordinating Comm., Inc. v. United States Atomic Energy Comm'n, 449 F.2d 1109 (D.C. Cir. 1971). While the National Environmental Policy Act, 42 U.S.C. $\S 4321$ (Supp. 1975), allows administrative discretion with respect to balancing substantive goals, it contemplates stricter judicial scrutiny of the "procedural duties" it created. 449 F.2d at 1115 n. 13.

[R]eviewing courts probably cannot reverse a substantive decision on its merits . . . unless it be shown that the actual balance of costs and benefits that was struck was arbitrary or clearly gave insufficient weight to environmental values. But if the decision was reached procedurally without individualized consideration and balancing of environmental 
legislatively determined classifications. In the procedural due process context, the Supreme Court has accommodated cost questions not so much in the threshold determination of the need for a hearing as in its willingness to modify the form, formality, and timing of hearings according to broader institutional and financial considerations. ${ }^{146}$ The Court has also strictly confined the doctrinal development of cases establishing indigents' rights to governmentally provided services. ${ }^{147}$ In equal protection adjudication, the Court has resisted an interventionist approach in reviewing social welfare program classifications. ${ }^{148}$

These "right to" and "inequality" issues are treated in the following sections in which consideration is given to two facets of the problem: defining substantive constitutional doctrine, and formulating appropriate remedies.

\section{A. The Problem of Access to Necessary Medical Services}

The questions addressed in this subsection are whether government has an affirmative duty to provide access for indigents to certain necessary medical

factors-conducted fully and in good faith-it is the responsibility of the courts to reverse.

Id. at 1115

Thus, for example, a union's claim that the federal government undervalued workers' health in establishing safety standards for the asbestos industry was rejected by the District of Columbia Circuit Court of Appeals, which applied a deferential standard of review. Industrial Union Dep't, AFL-CIO v. Hodgson, 499 F.2d 467 (D.C. Cir. 1974). Moreover, it seems that differential valuations of human life for different companies will be imposed by federal agencies and sustained by the courts. $C f$. Portland Cement Ass'n v. Ruckelshaus, 486 F.2d 375, 389-90 (D.C. Cir. 1973). When an agency imposes safety standards on all firms in an industry, it implicitly is valuing the lives of some workers more highly than others if costs of attaining the standards vary according to firm. For example, if an occupational safety standard would cost one asbestos firm one million dollars to achieve but would cost another firm of similar size and output five million dollars to achieve, there is an implicit inequality in values assigned to health of the workers in the two plants. Claims of impermissible unequal treatment would not likely receive a warm embrace by the courts, however; this is a judicial recognition that equality may be measured in terms of outcomes, when that is an administrative or legislative choice, even if not normally required by the Constitution. See, e.g., McInnis v. Shapiro, 293 F. Supp. 327 (1968), aff'd sub nom. McInnis v. Ogilvie, 394 U.S. 322 (1969) (per curiam); San Antonio Independent School Dist. v. Rodriguez, 411 U.S. 1 (1973). Normally, courts will find it easier to judge equality in terms of inputs (compare Hawkins v. Town of Shaw, 437 F.2d 1286 (5th Cir. 1971), aff'd en banc, 461 F.2d 1171 (5th Cir. 1972), with Beal v. Lindsay, 468 F.2d 287 (2d Cir. 1972)), though this is not always so. See, e.g., Brown v. Board of Educ., 347 U.S. 483 (1954); Mclaurin v. Oklahoma State Board of Regents, 339 U.S. 637 (1950); Sweatt v. Painter, 339 U.S. 629 (1950); Mills of Board of Educ., 348 F. Supp. 866 (D.D.C. 1972); cf. Yick Yo v. Hopkins, 118 U.S. 356 (1886).

146. See Mathews v. Eldridge, 424 U.S. 319 (1976); Goss v. Lopez, 419 U.S. 565 (1975); Wolff v. McDonnell, 418 U.S. 539 (1974); Morrissey v. Brewer, 408 U.S. 471 (1972).

147. See, e.g., Ortwein v. Schwab, 410 U.S. 656 (1973); United States v. Kras, 409 U.S. 434 (1973).

148. Some indications that the Court would assume a more activist role in cases perceived as micro eligibility issues rather than macro resource allocation questions have been blunted by the Court's recent statement that it will sustain Congress' "substantive policy determination that limited resources would not be well spent in making individual determinations." Weinberger v. Salfi, 422 U.S. 749, 784 (1975). See also Mathews v. Lucas, 427 U.S. 495 (1976). See generally text at section II.B.2.c. infra. 
services $^{\mathbf{1 4 9}}$ and if so what the scope of that obligation is. Although initially pitched as issues of inequality, ${ }^{150}$ these situations are now more often seen as raising issues of substantive due process. ${ }^{151}$

\section{The Duty to Provide Access}

The Supreme Court in the Burger era seems to have scotched the idea, tentatively advanced during the Warren years, ${ }^{152}$ that wealth inequalities ${ }^{153}$ will be closely scrutinized by the federal judiciary. ${ }^{154}$ But the Court has recognized that indigent individuals may have a claim to government-supported access to certain services. Thus, for example, persons unable to pay court costs in divorce actions are entitled to have those costs waived (and expenses for such things as notice borne by the state). ${ }^{155}$ The Court has taken pains, however, to limit this doctrine, refusing (by a five to four vote) to apply it to

149. Although the cases are almost all limited to indigents' access to certain government services, there are at least three areas in which cases involving access for non-indigents were considered favorably. In Harper v. Virginia Board of Elections, 383 U.S. 663 (1966), the Court invalidated the poll tax as an impermissible means of raising revenue. Non-poor as well as poor were exempted from such payment, even though the $\$ 1.50$ provided no barrier to the non-poor.

In the area of ballot access, the Court in Bullock v. Carter, 405 U.S. 134 (1972), struck down Texas's high filing fee for candidates, contrasting it with the more modest fees in other states. Although the Court subsequently required alternative access for indigents unable to meet even more modest filing fees, without specifying whether non-indigents could avail themselves of the alternative, Lubin v. Panish, 415 U.S. 709 (1974), Bullock protects non-indigents as well as indigents.

A third case favorable to provision of services to non-indigents is Mills v. Board of Educ., 348 F. Supp. 866 (D.D.C. 1972), where the court ordered the school board to provide alternative education for the handicapped. The class there apparently was not defined by wealth, see $348 \mathrm{~F}$. Supp. at 870 , and presumably all handicapped children would fall within the court's decree, regardless of parental income.

150. The argument runs as follows in an analogous area: An indigent, who cannot effectively exercise the statutory right of appeal in a criminal case because he cannot purchase a transcript, is unfairly discriminated against unless government provides a free transcript. See Douglas v. California, 372 U.S. 353 (1963); Griffin v. Illinois, 351 U.S. 12 (1956); cf. Tate v. Short, 401 U.S. 395 (1971); Williams v. Illinois, 399 U.S. 235 (1970). But see United States v. MacCollum, 426 U.S. 317 (1976). See generally note 240 infra.

151. This was the view urged by the late Justice Harlan. See Williams v. Illinois, 399 U.S. 235, 259-60 (1970) (Harlan, J., concurring). The Court has considered these "right to" cases in the context of both equal protection and due process. Compare Tate v. Short, 401 U.S. 395 (1971) and Lindsey v. Normet, 405 U.S. 56 (1972) (equal protection), with Boddie v. Connecticut, 401 U.S. 371 (1971) and Ortwein v. Schwab, 410 U.S. 656 (1973) (due process). See note 240 infra. Issues of procedural due process were considered in the text at section I supra.

152. See, e.g., McDonald v. Board of Election Comm'rs, 394 U.S. 802 (1969); Harper v. Virginia Board of Elections, 382 U.S. 663 (1966).

153. That is, classifications based on wealth criteria or that had disproportionate impacts on less wealthy persons. $C f$. Bullock v. Carter, 405 U.S. 134 (1972); see text at section II.B.3. infra.

154. See San Antonio Independent School Dist. v. Rodriguez, 411 U.S. l (1973); James v. Valtierra, 402 U.S. 137 (1971).

155. Boddie v. Connecticut, 401 U.S. 371 (1971). 
bankruptcy filing fees ${ }^{156}$ and to a filing fee prerequisite to judicial review of an administrative denial of welfare. ${ }^{157}$ The Court in recent years has also limited earlier guaranteed-access cases in criminal proceedings. Although counsel must be provided to indigent defendants for the first criminal appeal as of right, ${ }^{158}$ the state is not obligated to furnish counsel for subsequent discretionary appeals (such as to the United States Supreme Court). ${ }^{159}$ And the state can condition its financial assistance to indigent defendants on a governmental claim to subsequent reimbursement if the person becomes able to pay. ${ }^{160}$

These cases lend some plausibility to the claim of $\mathrm{Mr}$. Jones the hemophiliac that he has a constitutionally legitimate entitlement to government assistance, provided he would die without such aid and provided no reasonable alternative remedies are likely to succeed. The three characteristics that seem to have mattered most to the Court are (a) the importance of the services and their "constitutional connections;"161 (b) the degree of state monopolization of access to them; ${ }^{162}$ and (c) the element of total deprivation based on lack of funds. ${ }^{163}$

\section{a. Importance and Constitutional Connections}

Jones could reasonably argue that life-saving medical treatment is the highest order value under the Constitution. The fundamental nature of the interest is self-evident since its denial "entails the ultimate loss."164 Also there is ample legislative language to support the policy argument that broad distribution of basic medical services is a high government priority ${ }^{165}$ though in other contexts the Court has refused to validate similar types of arguments. ${ }^{166}$ Most importantly, the core interest in sustaining life has very intimate constitutional connections, appearing in the texts of both the fifth and fourteenth amendments. This nexus seems to be important for a Court wary of expanding the cadre of preferred protected individual interests. ${ }^{167}$

156. United States v. Kras, 409 U.S. 434 (1973).

157. Ortwein v. Schwab, 410 U.S. 656 (1973). But cf. Lindsey v. Normet, 405 U.S. 56, 74

(1972) (holding double bond requirement for appeal a violation of equal protection).

158. Douglas v. California, 372 U.S. 353 (1963).

159. Ross v. Moffit, 417 U.S. 600 (1974).

160. Fuller v. Oregon, 417 U.S. 40 (1974).

161. San Antonio Independent School Dist. v. Rodriguez, 411 U.S. 1, 30-36 (1973); United

States v. Kras, 409 U.S. 434, 444-45 (1973).

162. See Maher v. Roe, 45 U.S.L.W. 4787, 4789 n.5 (U.S. June 20, 1977); Boddie v. Connecticut, 401 U.S. 371, 375-77 (1971).

163. San Antonio Independent School Dist. v. Rodriguez, 411 U.S. 1, 20-25 (1973).

164. Note, Due Process, supra note 17, at 1741.

165. Hospital Survey and Construction Act (Hill-Burton Act), 42 U.S.C. $\S 291$ (1974); National Health Planning and Resources Development Act of 1974, 42 U.S.C. $\$ 300 \mathrm{~K}(\mathrm{a})(1)$ (1975):

"The achievement of equal access to quality health care at a reasonable cost is a priority of the Federal Government."

166. Cf. Dandridge v. Williams, 397 U.S. 471 (1970).

167. See San Antonio Independent School Dist. v. Rodriguez, 411 U.S. 1, 30-36 (1973). 


\section{b. State Monopolization}

The question of state monopolization is much more complex. The criminal justice cases reflect a clear governmental monopoly over a system of dispute settlement, where an unwilling defendant is being "haled into court"168 and the state is being required to provide an attorney or a transcript to protect him and preserve the presumption of innocence. ${ }^{169}$ In the divorce case, Boddie v. Connecticut, ${ }^{170}$ the Court drew an analogy to the plight of the criminal defendant since the state requires that what might otherwise be a private dispute be settled through a single, specific governmentally mandated process. ${ }^{171}$ The lack of adequate access alternatives played a pivotal role in Boddie, and has been a point stressed by the Court in such areas as candidate access to the ballot. ${ }^{172}$ In Jones's situation, the problem becomes whether alternative treatment possibilities exist, and whether government somehow has assumed responsibility for the lack of available alternatives ${ }^{173}-i . e$. , whether a court

168. Gideon v. Wainwright, 372 U.S. 335, 344 (1963).

169. On the courts' responsibility to maintain the presumption of innocence, see Estelle $v$. Williams, 425 U.S. 501, 502-05 (1976), where the Court said that the government cannot compel a criminal defendant to be tried in prison garb.

170. 401 U.S. 371 (1971).

171. Id. at 375-77. In the recent decision in which a state's right to refuse to pay for abortions was sustained, the Court emphasized that since the state had "made no attempt to monopolize the means for terminating pregnancies through abortion," the case was distinguishable from the divorce at stake in Boddie. Maher v. Roe, 45 U.S.L.W. 4787, 4789 n.5, 4791 n.13 (U.S. June 20, 1977).

172. American Party of Texas v. White, 415 U.S. 767 (1974); Storer v. Brown, 415 U.S. 724 (1974); Lubin v. Panish, 415 U.S. 709 (1974); Bullock v. Carter, 405 U.S. 134 (1972).

173. Governmental responsibility could be imposed in one of two ways. First, a positivistic approach, following Rawls and Michelman, could be used. See J. Rawls, A ThEory of Justice (1971); Michelman, The Supreme Court, 1968 Term-Foreword: On Protecting the Poor through the Fourteenth Amendment, 83 HARv. L. REv. 7 (1969) [hereinafter referred to as Michelman, Foreword]; Michelman, In Pursuit of Constitutional Welfare Rights: One View of Rawls' Theory of Justice, 121 U. PA. L. REv. 962 (1973) [hereinafter referred to as Michelman, Welfare Rights]. This would assign to government an affirmative duty to provide indigents minimum levels of basic or necessary services. See note 240 infra. While some language in recent opinions of the new majority reflects an awareness of this position, see San Antonio Independent School Dist. v. Rodriguez, 411 U.S. 1, 36-37 (1973), the present members of the Court appear unwilling to expand notions of societal responsibility or culpability to cover situations not intentionally caused by actions of governmental officials. See, e.g., Pasadena City Board of Educ. v. Spangler, 423 U.S. 161 (1976) (courts cannot assign responsibility to school board for annual shifting of attendance patterns to accommodate changes in demographic trends); Milliken v. Bradley, 418 U.S. 717 (1974) (prohibiting inter-district school busing to alleviate metropolitan race segregation, absent finding of responsibility by suburban school officials for causing segregation). See also O'Connor v. Donaldson, 422 U.S. 563, 578 (1975) (Burger, C.J., concurring).

Secondly, responsibility could be imposed on government if there were a finding that restrictions on capital investment through regulation generated an artificial shortage of treatment facilities, equipment, or services. As of 1973, about half the states had certificate-of-need laws, requiring approval of new expenditures for specified items. See Havighurst, Regulation of Health Facilities and Services by "Certificate of Need," 59 VA. L. Rev. 1143, 1144 n.4 (1973); Salkever \& Bice, The Impact of Certificate-of-Need Controls on Hospital Investment, 54 Milbank Memorial Fund Q.: Health \& Soc'y 185 (1976). The National Health Planning and Resources Development Act of 1974,42 U.S.C. $\S 300 \mathrm{~m}-2$ (Supp. 1975), requires states without a certificate-of-need law to enact one. 
would find the monopolization analogy to the criminal process, ${ }^{174}$ divorce proceedings, ${ }^{175}$ candidate ballot access, ${ }^{176}$ and voting ${ }^{177}$ persuasive with respect to life-saving medical resources.

\section{c. Absolute Deprivation}

The absolute deprivation factor became important in the bankruptcy filing fee case, United States $v$. Kras, ${ }^{178}$ and subsequently in the context of a challenge to the prevailing method of financing public education. ${ }^{179}$ In Kras, Justice Blackmun believed that a person seeking to file bankruptcy papers could find the requisite funds and therefore was not really deprived of the benefits of bankruptcy. ${ }^{180}$ In the school finance case, San Antonio Independent School District $v$. Rodriguez, ${ }^{181}$ an equal protection challenge to the district-based tax system for raising education revenues, Justice Powell emphasized that the challenge was to comparative per pupil expenditure levels; in part since no absolute deprivation of education was involved, the Court refused to intervene. ${ }^{182}$

In addition to certificate-of-need laws, government controls much of research spending in the country, though by no means does it have a monopoly on such expenditures. The Food and Drug Administration (FDA) can control access to the American market for drugs that do not satisfactorily demonstrate their acceptability and usefulness. There have been cases of disagreement about the wisdom of these restrictions, especially where some link to cancer is the cause of the ban on the drug. See, e.g., Blank, The Delaney Clause: Technical Naivete and Scientific Adrocacy in the Formulation of Public Health Policies, 62 CALlf. L. REv. 1084 (1974). It is highly unlikely that a legitimate FDA decision to ban a drug, on grounds of safety, could serve as a predicate for imposing responsibility on government to provide life-saving medical treatment because of the alleged monopolization of access.

174. Cf. Douglas v. California, 372 U.S. 353 (1963); Griffin v. Illinois, 35 l U.S. 12 (1956).

175. Cf. Boddie v. Connecticut, 401 U.S. 371 (1971).

176. Cf. American Party of Texas v. White, 415 U.S. 767 (1974); Storer v. Brown, 415 U.S. 724 (1974); Lubin v. Panish, 415 U.S. 709 (1974).

177. Cf. Harper v. Virginia Board of Elections, 383 U.S. 663 (1966).

178. 409 U.S. 434 (1973).

179. San Antonio Independent School Dist. v. Rodriguez, 411 U.S. 1 (1973). This absolute deprivation notion has been a critical factor in voting rights equal protection cases as well. Compare Kusper v. Pontikes, 414 U.S. 51 (1973) and O'Brien v. Skinner, 414 U.S. 524 (1974), with Rosario v. Rockefeller, 410 U.S. 752 (1973) and McDonald v. Board of Election Comm'rs, 394 U.S. 802 (1969); see note 302 infra.

180. This comment drew a stinging rebuke from Justice Marshall in dissent where he pointedly called Justice Blackmun insensitive to the problems the poor might have in obtaining what seemed to the Court a modest sum:

It may be easy for some people to think that weekly savings of less than $\$ 2$ are no burden. But no one who has had close contact with poor people can fail to understand how close to the margin of survival many of them are... It is perfectly proper for judges to disagree about what the Constitution requires. But it is disgraceful for an interpretation of the Constitution to be premised upon unfounded assumptions about how people live.

409 U.S. at 460.

181. 411 U.S. 1 (1973).

182. Id. at 23-25. See generally Goldstein, Interdistrict Inequalities in School Financing: A Critical Analysis of Serrano v. Priest and its Progeny, 120 U. PA. L. REv. 504 (1972). 
The problem of access to scarce life-saving medical resources is difficult when viewed from this dimension. All too frequently, we tend to view medical services as an all-or-nothing package when they may very well be disaggregated. ${ }^{183}$ Ordinarily, medical services might be analogized to the education situation described in Rodriguez: that is, more care may be better (arguably improving the likelihood of cure or reducing the likelihood of death), but rational consumers can and should assess whether incremental expenditures for quality are worth their cost. ${ }^{184}$

The acute nature of certain catastrophic diseases, however, may more nearly conform to the popular belief that medical treatment is indivisible. If Mr. Jones does not obtain sufficient blood and medication when bleeding, he will perish. Unlike other medical situations, this one might very well pose the all-or-nothing dilemma-the threshold below which there really is an absolute deprivation.

Of course, establishing the indivisibility of certain life-saving medical treatment does not resolve the initial question of governmental responsibility, nor does it resolve the problem of defining the scope ${ }^{185}$ of that responsibility, if imposed ${ }^{\mathbf{1 8 6}}$ - a problem addressed next.

\section{Nature and Scope of Governmental Responsibility}

One of the real difficulties with judicial establishment of positivistic governmental duties to provide services is the problem of defining the nature and extent of the responsibility. In the divorce situation, for example, the obligation was fairly narrow, meeting the statutory requirements for a filing fee and the publication of notice. ${ }^{187}$ When government is obliged to furnish free legal counsel in criminal cases, the Court has said that there is no duty to provide the best counsel money can buy. Presumably, court appointment of any licensed attorney would satisfy the constitutional command.

In extending the "right to" notion to other governmentally supplied services, especially life-saving medical care, courts face a much more differen-

183. See Havighurst \& Blumstein, supra note 1, at 12-13.

184. See V. Fuchs, Who Shall Live?: Health, Economics and Social Choice (1974); Fuchs, The Contribution of Health Services to the American Economy, in Economics of Health Care 57 (J). Mckinlay ed. 1973); Havighurst \& Blumstein, supra note 1; Lave \& Lave, Medical Care and its Delivery: An Economic Appraisal, 35 Law \& Contemp. Prob. 252 (1970); Blumstein \& Zubkoff, supra note 12.

185. Assuming there is a duty, the question remains as to its extent. For instance, does the "adequacy" concept require a standard of treatment that satisfies professional standards? The "adequate" prison facilities mandated by Judge Johnson accorded with professionally developed standards. See James v. Wallace, 406 F. Supp. 318, 331-35 (1976). See generally Michelman, Foreword, supra note 173; Michelman, Welfare Rights, supra note 173; Schoettle, The Equal Protection Clause in Public Education, 71 Colum. L. REv. 1355, 1388-1419 (1971). See also notes 439-48 infra and accompanying text.

186. See note 173 supra.

187. Boddie v. Connecticut, 401 U.S. 371, 372 (1971). 
tiated set of services, ${ }^{188}$ and limitations will be extremely difficult to impose. As a recent study by the Council on Wage and Price Stability reaffirms, the medical sector has a penchant for consuming an ever-increasing proportion of our nation's wealth. ${ }^{189}$ Accustomed to ordering services without regard to cost factors-permitted in large part because of the pervasive third party payment mechanism ${ }^{190}$ as well as the traditional autonomy of the medical profession ${ }^{191}$ and its concomitant insulation from external review-medical providers cannot blithely be written society's blank check.

Historical experience with cost escalation, resulting from both price and utilization increases, ${ }^{192}$ indicates that the medical sector can probably spend, at least marginally productively, all resources society is willing to allocate to it. ${ }^{193}$ Unconstrained governmental underwriting of the costs for life-saving medical services is an open invitation to medical science to develop ever more sophisticated technology whose cost is unknown and whose effectiveness is untested. ${ }^{194}$

In the medical sector, it has been extremely difficult to persuade providers to recognize that anything but the "best possible" is acceptable. ${ }^{195}$ This profes-

188. See Posner, Regulatory Aspects of National Health Insurance Plans, 39 U. CHu. L. Rev. 1, 8-10 (1971).

189. See Council on Wage and Price Stability Staff Report, The Problem of Rising Health Care Costs (April 1976). The health sector in 1975 consumed 8.3 per cent of Gross National Product (GNP), an increase of 41 per cent from 5.9 per cent of a smaller GNP in 1965. In fiscal 1975 , per capita expenditures amounted to $\$ 547$, or $\$ 2188$ per family of four. $I d$. at ii. Increases in health spending arise from expanding utilization and rising price levels. See id. at 2-9. See also Stuart \& Stockton, Control ouer the Utilization of Medical Serices, 51 Milbank Memorial Fund Q.: Health \& Soc'y 341 (1973).

190. See generally Blumstein \& Zubkoff, supra note 12.

191. See generally Blumstein, supra note 1, at 286.

192. See note 189 supra.

193. McClure, The Medical Care System under National Health Insurance: Four Models, $1 \mathrm{~J}$ Health Politics, Policy \& Law 22, 24 (1976).

194 Dr. Howard H. Hiatt, Dean of Harvard's School of Public Health, has poignantly written about the need to establish criteria for determining whether research efforts will likely result in socially optimal outcomes, whose benefits outweigh their costs. See Hiatt, Too Much Technology?, Wall Street Journal, June 24, 1976, at 12, cols. 4-6. Harry Schwartz has sounded the same theme, noting the concern with the ever-increasing expenditures on expensive equipment, whose benefits may be marginal (though positive). See Schwartz, On Medical Progress. N.Y. Times, Apr. 13, 1976. at 33, cols. 5-6. See also Gruenberg, The Failures of Success, 55 Milbank Memorial Fund Q.: HEalth AND Society 3 (1977); Iglehart, The Cost and Regulation of Medical Technology; Future Policy Directions, 55 Milbank Memorial Fund Q.: Health and Society 25 (1977); McClure, supra note 193.

195. When he was the chief health officer at the Department of Health, Education, and Welfare, Dr. Charles C. Edwards, then Assistant Secretary for Health, observed that the PSRO program could be used by physicians as a "vehicle for change whereby the best and most effective of care becomes the standard of care." Improing the Nation's Health Care System, address by Charles C. Edwards, 1973 Annual Program Conference, National Association of Blue Shield Plans, Chicago 10 (Oct. 25, 1973). Influential members of Congress, such as Representative Paul Rogers, also have advocated the "highest possible" level of quality in medical treatment for all. See Havighurst \& Blumstein, supra note 1, at 6 n.l. 
sional "quality imperative"196 contributes to the notorious ineffectiveness of utilization control. ${ }^{197}$ What has been almost impossible to achieve through formal programs of utilization review ${ }^{198}$ - that is, disallowing governmental payment for marginally productive treatment that is of lower priority-has at least been theoretically possible as a constitutional matter. ${ }^{199}$ The Courts face terribly difficult dilemmas and practical problems in either constitutionalizing the blank check approach or setting judicially mandated standards about which there will be no professional consensus. ${ }^{200}$

Despite judicial awareness of the problems of intervention, lower courts have expanded earlier "right to" decisions to include a constitutionally based right to treatment on the part of patients in state mental institutions; ${ }^{201} \mathrm{a}$ right to minimum conditions in prisons; ${ }^{202}$ and a right to suitable special educational opportunities for the mentally retarded. ${ }^{203}$ Thus the Fifth Circuit has held that mental patients, a majority of whom were civilly committed, had a constitutional entitlement to receive adequate treatment, and civilly committed

196. See Havighurst \& Blumstein, supra note 1, at 20-38; cf. V. Fuchs, Who Shall Live?, supra note 184.

197. See Havighurst \& Blumstein, supra note 1, at 38-40; S. REP. No. 1230, 92d Cong., 2d Sess. 254, 255 (1972) (utilization control under Medicare had been "ineffective as a curb to unnecessary use of institutionalized care and services").

198. See generally Havighurst \& Blumstein, supra note 1; Stuart \& Stockton, supra note 189.

199. See Association of Am. Physicians \& Surgeons v. Weinberger, 395 F. Supp. 125 (N.D. Ill. 1975), aff'd mem. 423 U.S. 975 (1975) (upholding constitutionality of PSRO review as prerequisite to Medicare and Medicaid reimbursements). But of. American Medical Ass'n v. Weinberger, 395 F. Supp. 515 (N.D. Ill. 1975), aff'd 522 F.2d 921 ( 7 th Cir. 1975) (granting preliminary injunction against enforcement of Medicare regulation requiring review of hospital admissions within twenty-four hours). See also Maher v. Roe, 45 U.S.L.W. 4787 (U.S. June 20, 1977).

200. Physicians are reluctant to accept either professional or lay review. Professional review is difficult because physicians tend to disagree on what constitutes good medical care-professional prescription of standards would result in a "cook book" approach to medicine, unacceptable not only to physicians whose "clinical judgment" is inhibited, but also to patients who see individualized care as an essential part of their medical treatment.

While there is disagreement among professionals as to what is good medical care and resistance to standardization that downplays subjective judgments, there is professional agreement that standards of medical care are too scientific for lay review. See generally Blumstein, supra note 1, at 285-87.

201. See, e.g., Wyatt v. Aderholt, 503 F.2d 1305 (5th Cir. 1974); Davis v. Watkins, 384 F. Supp. 1196 (N.D. Ohio 1974); Welsch v. Likins, 373 F. Supp. 487 (D. Minn. 1974); Statchulak v. Coughlin, 364 F. Supp. 686 (N.D. Ill. 1973).

202. See, e.g., Rhem v. Malcolm, 507 F.2d 333 (2d Cir. 1974); Newman v. Alabama, 503 F.2d 1320 (5th Cir. 1974); Holt v. Sarver, 442 F.2d 304 (8th Cir. 1971).

203. See Mills v. Board of Educ., 348 F. Supp. 866 (D.D.C. 1972); Pennsylvania Ass'n for Retarded Children v. Pennsylvania, 334 F. Supp. 1257 (E.D. Pa. 1971), aff'd and settlement approved by three-judge court, 343 F. Supp. 279 (E.D. Pa. 1972). Contra, New York State Ass'n for Retarded Children, Inc. v. Rockefeller, 357 F. Supp. 752 (E.D.N.Y. 1973). In Lau v. Nichols, 414 U.S. 563 (1974) (finding a statutory theory for right to bilingual education under Civil Rights Act of 1964), and O'Connor v. Donaldson, 422 U.S. 563 (1975) (finding a right to sue for deprivation of liberty without right to treatment rationale), the Supreme Court declined to ratify lower court decisions premised in part, at least, on a "right to" rationale. The Court found nonconstitutional grounds for decision. 
mentally retarded patients had a similar right to "habilitation." ${ }^{204}$ In Mills $v$. Board of Education, ${ }^{205}$ where no custodial care was involved, a constitutional duty was imposed on the District of Columbia school board to provide an educational opportunity for retarded children, even if tuition grants need be established to pay for such education. In the context of prisons, several circuit courts of appeals have found conditions to constitute "cruel and unusual punishment" under the eighth amendment and required the provision of specifically enumerated services and improvement of designated conditions. ${ }^{206}$ In at least one case, it was inadequate medical treatment and facilities ${ }^{207}$ that led to a finding of constitutional violation.

The courts have argued that incarceration disables an inmate from procuring assistance and, more importantly, creates total dependency on the state for treatment. ${ }^{208}$ As the Sixth Circuit has found, "[a]n individual incarcerated . . . becomes both vulnerable and dependent upon the state to provide certain simple and basic human needs." ${ }^{209}$ Even in these prison and mental hospital cases, the courts seem reluctant to interfere in state administrative practice, but this reticence has not barred aggressive imposition of far-reaching orders that are remarkably specific in their detail. ${ }^{210}$

While some courts have recognized the problem of judicial reassignment of priorities, ${ }^{211}$ others have not at all clearly identified the trade-offs involved, much less sought to justify judicial mandate for expenditure of scarce funds on mentally retarded children rather than, say, expenditure of those dollars on enrichment programs for the gifted. ${ }^{212}$ The death penalty cases $^{213}$ are interesting in this regard since none of the decisions in either 1972 or

204. Wyatt v. Aderholt, 503 F.2d 1305, 1314 (5th Cir. 1974). See generally Estelle v. Gamble, 429 U.S. 97 (1976).

205. 348 F. Supp. 866 (D.D.C. 1972).

206. See, e.g., Inmates of Suffolk County Jail v. Eisenstadi, 360 F. Supp. 676 (D. Mass. 1973), aff'd, 494 F.2d 1196 (1st Cir. 1974); Gates v. Collier, 349 F. Supp. 881 (N.D. Miss. 1972), aff'd, 501 F.2d 1291 (5th Cir. 1974); Collins v. Schoonfield, 344 F. Supp. 257 (D. Md. 1972); Holt v. Sarver, 309 F. Supp. 362 (E.D. Ark. 1970), aff'd, 442 F.2d 304 (8th Cir. 1971).

207. These included (1) gross understaffing of medical facilities; (2) inadequate physical plant and equipment; (3) inadequate medical treatment program, including the procurement and distribution of drugs and supplies; and (4) numerous case examples of corrections staff members denying inmates rights to be examined or treated by trained personnel. See Newman v. Alabama, 349 F. Supp. 278, 281-85 (M.D. Ala. 1972), aff'd in part, 503 F.2d 1320 (5th Cir. 1974), cert. denied, 421 U.S. 948 (1975). See generally Estelle v. Gamble, 429 U.S. 97 (1976) and note 30 supra.

208. Fitzke v. Shappell, 468 F.2d 1072 (6th Cir. 1972).

209. Id.

210. See, e.g., Wyatt v. Stickney, 344 F. Supp. 373, 379-80 (M.D. Ala. 1972), 344 F. Supp. 387 395.407 (M.D. Ala. 1972); note 425 infra.

211. Rhem v. Malcolm, 507 F.2d 333, 340-42 (2d Cir. 1974).

212. See Mills v. Board of Educ., 348 F. Supp. 866 (D.D.C. 1972); $c f$. Schoettle, supra note 185 , at 1388-93.

213 . Roberts v. Louisiana, 428 U.S. 325 (1976); Woodson v. North Carolina, 428 U.S. 280 (1976); Proffitt v. Florida, 428 U.S. 242 (1976); Jurek v. Texas, 428 U.S. 262 (1976); Gregg v. Georgia, 428 U.S. 153 (1976); Furman v. Georgia, 408 U.S. 238 (1972). 
1976 seriously considered costs of incarceration as a factor in the constitutional analysis. The plurality opinion of Justice Stewart in Woodson $v$. North Carolin $a^{214}$ imposes a duty of individualized decision making in capital cases, albeit under specific legislative guidance, because of the eighth amendment's "fundamental respect for humanity." This poses an interesting standard for those (such as our hemophiliac) who face the "finality"215 of death without government support. Of course, there is a fantastic overlay of symbolic issues in the death penalty controversy, creating significant external costs to our self-image as a humanitarian society, committed to preservation-not destruction-of human life. ${ }^{216}$

The failure to address costs in the death penalty constitutional debate is mirrored in the trial court's approach to the Karen Quinlan case. ${ }^{217}$ For whatever reason, cost considerations have played virtually no role in the public debate about the Quinlan case, even though they clearly loom in the background. Indeed, trial Judge Muir's rather lengthy and careful opinion, prepared under the glare of assured public scrutiny, did not even mention costs. For the lower court, it was evidently immaterial what costs were associated with its determination of the substantive issues. The opinion failed to consider either questions of aggregate costs, or alternative expenditure opportunities, and, in fact, never mentioned who was paying for the continuation of treatment. $^{218}$

The fact that the trial court did not feel obliged to deal with cost questions, though striking, is neither surprising nor necessarily inappropriate. Cases of life and death, where the well-being of identifiable individuals is at stake, evoke humanitarian impulses from society, ${ }^{219}$ and consideration of costs

214. 428 U.S. at 304 .

215. Id. Admittedly the death penalty case and the unfunded hemophiliac are dissimilar in many respects, but the problem of assigning government responsibility for making life and death decisions is common to both.

216. See generally Zeckhauser, Catastrophic Illness, supra note 7. These sentiments have been voiced by Justices Brennan and Marshall in the death penalty context. In Furman v. Georgia, 408 U.S. 238, 257 (1972) (Brennan, J., concurring), Justice Brennan found capital punishment unconstitutional because it treats "members of the human race as nonhumans" and is "inconsistent with the fundamental premise ... that even the vilest criminal remains a human being possessed of common human dignity." Id. at 273. In Gregg v. Georgia, 428 U.S. 153, 227 (1976) (Brennan, $\mathrm{J}$., dissenting), he reiterated his view that the "state, even as it punishes, must treat its citizens in a manner consistent with their intrinsic worth as human beings." Similarly, in Gregg Justice Marshall objected to retribution as a rationale because it is a "total denial of the wrong-doer's dignity and worth." $I d$. at 231 .

217. In re Quinlan, 137 N.J. Super. 227, 348 A.2d 801 (1975).

218. The state, as it turns out, had assumed payment responsibility because Karen was incompetent, dependent, and destitute.

219. See G. Calabresi, Tragic Choices, supra note 13. This is even true when these individuals have committed heinous crimes. See Gregg v. Georgia, 428 U.S. at 227, 231 (Brennan, J., dissenting; Marshall, J., dissenting); Woodson v. North Carolina, 428 U.S. 280, 304 (1976) (plurality opinion). 
becomes increasingly difficult to accept as a legitimate, overt subject of debate. ${ }^{220}$

At the policy level, therefore, the Quinlan debate conforms to our expectations once society is confronted with an individual life in peril. ${ }^{221}$ But the involvement of the judiciary and the trial court decision in Quinlan raise especially troublesome concerns. ${ }^{222}$ Faced with such a decision-making role, Judge Muir diverted attention away from broad questions of social policy and focused instead on the only issue over which he had control: whether or not Karen Quinlan would continue to live. ${ }^{23}$ By the time of the hearing in the

220. It is quite apparent, for example, that public dialogue about whether to send the Coast Guard (at public expense) to rescue a millionaire yachtsman floundering off-shore would not give prominent attention to nice questions of cost, likelihood of success, negligence of the crew, desirability of transferring wealth to millionaires, and so forth. Even when the search is abandoned, the Coast Guard is likely to characterize the matter as "hopeless" (what Karen Quinlan's doctors were unwilling to say). It is not likely that the Coast Guard would issue a communique such as the following:

Upon more relaxed and sober consideration, we have concluded that the considerable costs of continuing the search outweigh the potential benefits since the likelihood of success is relatively small (though non-negligible) and since only a small number of lives is at stake anyhow. Moreover, balancing social goals, we conclude that the transfer of wealth to millionaires is a low priority social goal, and if further search activities are to be carried out, they must be paid for by the family.

See generally Blumstein \& Zubkoff, supra note 12; Havighurst \& Blumstein, supra note 1; Zeckhauser, Catastrophic Illness, supra note 7.

221. See generally C. Fried, An Anatomy of Values, supra note 5; Fried, The Value of Life, supra note 5; Schelling, The Life You Saze May Be Your Own, in Problems in Public Expenditure Analysis 127 (S. Chase ed. 1968).

222. The trial court, rather than permit a decentralized decision (by family and doctors), took it upon itself to answer the life and death question. But lacking legislatively determined standards, and unwilling to supply his own criteria that would take into account the variety of economic, social, and personal issues such choice raises, Judge Muir rendered a decision which largely ignored these issues. The choice for sustenance of life was made without consideration of alternative uses for the scarce resources involved. The trial court thus did not address the important societal questions of resource allocation raised by large expenditures on extraordinary medical care for people whose "salvageability" is very low. See text at section II.B. infra.

This is not to suggest that the New Jersey Supreme Court decision to permit a decentralized choice is totally problem free. Potential conflicts within the family as to the proper course of action-conflicts not mentioned by the court-might involve the judiciary in yet another difficult mediator role.

Recently, the United States Supreme Court addressed the problem of intra-family conflict in considering a Missouri law that required (a) the consent of a husband before a woman could have an abortion, and (b) the consent of a parent before an unmarried minor could have an abortion. In both situations, the Court ruled that the woman's interest in privacy, held to have included the decision whether to carry a pregnancy through to term, Roe v. Wade, 410 U.S. 113 (1973), outweighed any countervailing interests of either the state or other family members. Accordingly, it was impermissible for the state to require spousal or parental consent as a prerequisite to an abortion. Planned Parenthood of Cent. Mo. v. Danforth, 428 U.S. 52, 67-75 (1976).

Since the right to privacy recognized by the New Jersey Supreme Court in In re Quinlan, 70 N.J. 10, 355 A.2d 647 (1976), was derived from the abortion cases, presumably it would give primacy to the interests of the individual patient. In Karen Quinlan's case, of course, since she was comatose, the further question of who would represent her interests was at issue.

223. $C f$. Boomer v. Atlantic Cement, 26 N.Y.2d 219, 257 N.E.2d 870 (1970), a suit by residents to abate a polluting cement plant as a nuisance. The New York Court of Appeals there 
trial court, there seemed to be agreement among the parties that according to currently accepted standards of death, Karen was still "alive."224 Once having made that finding, Judge Muir perceived a "yes-no" decision (would the court authorize her death) rather than an "either-or" decision (would the funds be better spent elsewhere). ${ }^{225}$ Indeed, in an adjudicatory setting, courts typically face such limited decisions, constrained as they are to decide live cases and controversies among adversarial parties to a specific lawsuit. ${ }^{226}$

Institutionally, courts are called upon to resolve questions of constitutional interpretation; these decisions in turn can have significant budgetary consequences. Yet, as in the Quinlan situation, especially as framed by the trial judge, ${ }^{227}$ courts are not able to make trade-offs and are likely therefore to argue that funding questions are not their concern-they decide the outcome of a case, the political branches must find the money. ${ }^{228}$ This is not to deny that courts often are aware of competing allocation priorities, ${ }^{229}$ but since

refused to consider broad policy issues concerning the proper balance between economic productivity and a clean environment. Instead of treating the case as one of public nuisance, the court dealt with the private nuisance aspects, involving only the company and the individual homeowners who filed suit. Having thus narrowed its focus, the court denied abatement as a remedy because of the disproportionate economic costs of closing the polluting plant. Damages to the plaintiffs were awarded instead, and the plant remained open. By narrowing its focus, the court declined to provide a forum in which evidence of competing social costs and benefits of pollution control would be presented; such issues were remitted to the political process. At the same time, however, the decision admittedly omitted an array of relevant factors to an appropriate social policy choice. See text at section II.B. infra.

224. Although detinition of the terms "life" and "death" involves a value choice, it is often easier to make that choice at a definitional level. Thus redefinition can serve to defuse the "lifesaving imperative." See Havighurst, Blumstein, \& Bovbjerg, supra note 33. For example, the decision to perform a heart transplant implicates important symbolic values if a beating heart is equated with life. In such a case, the transplant is the trading of one life (the donor's) for another (the donee's), valuing that of the donee more than that of the donor and thus destructive of egalitarian values. By redefining death as the cessation of brain wave activity, we can make exactly the same choice, and still maintain those important values. $C f$. Lachs, Humane Treatment and the Treatment of Humans, 294 NEw ENG. J. MED. 838 (1976). Such redefinition, however, is not always possible, as is evident in the Quinlan case; broad consensus must be allowed to evolve as issues of this type arise. One possibility is to permit different standards to govern in different settings.

225. See Havighurst \& Blumstein, supra note 1, at 33-34, 50-5̌1. An either/or decision requires consideration of the trade-offs-i.e., the opportunity costs. A yes/no decision is made in a vacuum with no consideration of the other options available.

226. In New Jersey, apparently, no case or controversy requirement exists as a constitutional matter. In re Quinlan, 70 N.J. 10, 34, 355 A.2d 647, 660 (1976).

227. Judge Muir's decision hinged on whether or not Karen Quinlan was "by legal and medical definition alive." 137 N.J. Super. 227, 256, 348 A.2d 801,817 (1975). The questions of cost or quality of life were never raised.

228. "Humane considerations and constitutional requirements are not, in this day, to be measured or limited by dollar considerations." Jackson v. Bishop, 404 F.2d 571, 580 (8th Cir. 1968) (per Blackmun, J.); see Shapiro v. Thompson, 394 U.S. 618, 633 (1969); Rhem v. Malcolm, 507 F.2d 333, 342 (2d Cir. 1974). See also Wyatt v. Aderholt, 503 F.2d 1305, 1315 (5th Cir. 1974).

229. See, e.g. Dandridge v. Williams, 397 U.S. 471 (1970); Rhem v. Malcolm, 507 F.2d 333, 342 (2d Cir. 1974). 
meeting these other needs is not their immediate institutional concern, the problems are much more abstract or hypothetical. ${ }^{230}$

The Second Circuit, for example, in a prison case involving pretrial detainees, acknowledged that New York City's financial plight made costly expenditures for compliance with the court's decree difficult. The city contended that fire, police, and other essential services should receive priority over housing of those confined in jail; it contended as well that the conditions complained of in the Tombs could be found to exist among the unincarcerated inhabitants of the city. The court empathized with the former argument, though rejecting it; the latter argument it found "difficult to take . . . seriously." A sufficient response was that the hardships in the Tombs were "imposed by the City in the exercise of its power and custody over inmates." ${ }_{231}$

The prison, mental hospital, special education, death penalty, and Quinlan cases reflect the kinds of institutional difficulties courts have in resolving allocation problems. In these cases the court is constantly subject to second guessing ${ }^{232}$ about its spending priorities, especially those rigidly imposed by constitutional command. Moreover, in deciding cases which have a direct effect on human life (implicitly placing a value on a particular life), courts face the same kind of bias against confronting cost questions that other institutions of government do. ${ }^{233}$

230. Even under the New Jersey Supreme Court decision, Karen Quinlan would be forced to receive respirator treatment if a hospital ethics committee will not approve removal. In re Quinlan, 70 N.J. 10, 54, 355 A.2d 647, 672 (1976).

231. Rhem v. Malcolm, 507 F.2d 333, 338 (2d Cir. 1974).

232. A recalcitrant school board, for example, faced with an unpopular busing order that requires expenditure of additional funds for student transportation, could heighten community tension by dropping a popular program (such as football) and announcing that those funds are being used to pay for new school buses. In this way, the courts may also be politically vulnerable.

Counter examples, where a local school board will use a judicial decree to exact funds from a recalcitrant state legislature, are available. See Milliken v. Bradley, 45 U.S.L.W. 4873 (U.S. June $27,1977)$. In Milliken the Court upheld a district judge's order that required remedial programs as part of a desegregation decree in Detroit's public schools. The city school board supported the judge, who ordered that the State of Michigan pay an aliquot share of the costs of the remedial program. For a thorough discussion of the political and economic dynamics, see id. at 4880-82 (Powell, J., concurring).

233. This is an important perspective to bear in mind when thinking about the role courts can constructively play in constraining government decisions affecting human life.

Recent discussions of the disability benefits program have concluded that court decisions have modified stringent statutory standards of eligibility. See R. Dixon, Social Security Disability and Mass Justice: A Problem in Welfare Adjudication (1973); Liebman, The Definition of Disability in Social Security and Supplementary Security Income: Drawing the Bounds of Welfare Estates, 89 Harv. L. Rev. 833 (1976). These studies make the interesting point that administrative officials, even if closer to the individual making the claim, have a full range of experiences to consider when making an eligibility determination. Consequently, they can, and do, adhere more rigorously to standards imposed by statute or regulation in marginal cases. Typically, reviewing officials and courts face a smaller universe of cases and react to perceived injuscices in those situations, without measuring cases before them against other cases that arise. Professors Dixon and Liebman seem to respond differently to the relatively high reversal rates they observe-Dixon 
These cases do not give much comfort to Mr. Jones, the hemophiliac, whose unfamiliarity with the niceties of legal reasoning and whose intimacy with the reality of society's life and death decisions, make him unable to shrug off as "difficult to take . . seriously" the questions which for him are not satisfactorily answered: Why is it that in some circumstances a person convicted of a capital crime may have a constitutionally based and judicially enforced right, not only to life, but also to adequate living standards and medical treatment?234 Why do mentally retarded children have a higher constitutional claim to public funds so that they can learn to tie their shoe laces when Jones' life could be saved, and perhaps "salvaged"?235 Why is Karen Quinlan, irreversibly comatose, entitled to receive public funds to sustain her on (and deprive others from?) the respirator while Jones suffers the risk of death from injury?

Whatever rationale we may postulate as lawyers or economists, at the bottom line Jones does not have a claim on the governmental fisc-yet-because popular conceptions of communal responsibility have not advanced to the stage where the symbolic values are sufficiently implicated. ${ }^{236}$

Recognizing that we as a society find the context and the process of decision making to have important external effects that ultimately influence societal valuations of life, it is clear that society faces an important and difficult problem. It must define the nature and scope of state responsibility between private and public sectors, within the public sector, ${ }^{237}$ and between the courts and politically accountable officials.

\section{B. Determining Impermissible Inequality}

In addition to issues of access, major concerns raised by the Jones case center on his claim of unfair inequality. When Jones says to the government, "You spend to keep mass murderers alive, why not spend for me?" or when

advocating more restrained review. Liebman applauding the humanitarian impact of judicial intervention. See note 327 infra.

234. See Gregg v. Georgia, 428 U.S. 153,187 n.35 (1976) (plurality opinion): “We do not address here the question whether the taking of the criminal's life is a proportionate sanction where no victim has been deprived of life-for example, when capital punishment is imposed for rape, kidnapping, or armed robbery that does not result in the death of any human being." See also note 30 supra. Cf. Coker v. Georgia, 45 U.S.L.W. 4961 (U.S. June 29, 1977) (holding capital punishment for rape grossly disproportionate and excessive and therefore cruel and unusual in violation of the eighth amendment).

235. See Crane, supra note 10 , at 4 .

236. See generally note 456 infra and accompanying text.

237. Court-mandated expenditure of funds can have three kinds of allocative impact: intradepartmental reallocation-e.g., funding a court-ordered educational program for the handicapped by cutting a program for the gifted; interdepartmental reallocation-e.g., funding the court-ordered program by reducing the size of the police force. Both of these are reallocations within the public sector. The third kind of impact is a public-private intersector reallocation-e.g., funding the court-ordered program by raising taxes. See text at section II.C.2. infra. 
he asks, "Why should a convicted felon receive elaborate medical treatment free from government when I don't qualify?", he is asserting a violation of a basic precept of governmental action: like treatment for those similarly situated. ${ }^{238}$ This is the heart of the constitutional prohibition against state denial of "equal protection" 239 of the laws. ${ }^{240}$

\section{Standards for Justifying Uneven Treatment}

Differences in treatment by government must be adequately justified if they are to be sustained. ${ }^{241}$ When government classifies a certain group as eligible for a given benefit, ${ }^{242}$ thereby implicitly excluding others, the disadvantaged group, or members of that group, are entitled to have the state articulate a "legitimately defensible difference" 243 in order to justify the disadvantageous distinction. Much that comes under the heading of equal protection analysis is an attempt to determine what the content of the state's burden of justification should be. ${ }^{244}$

238. See generally Note, Developments in the Law: Equal Protection, 82 Harv. L. Rev. 1065 (1969).

239 . "[N]or shall any State . . deny to any person within its jurisdiction the equal protection of the laws." U.S. ConsT. amend. XIV, \& 1.

240. Considerations of equality were closely intertwined with concerns for access, as discussed in text at section II.A.I. supra. The initial cases indeed held that equal protection is violated by government's failure to provide transcripts to indigent criminal defendants who exercised their rights of appeal. Griffin v. Illinois, 351 U.S. 12 (1956). And the Court also ruled that refusal to provide counsel to an indigent criminal defendant for the first appeal as of right denied equal protection. Douglas v. California, 372 U.S. 353 (1963). Similarly, the Court has used an equal protection rationale to disallow imprisonment for indigents who would be released but for their inability to pay a fine. Tate v. Short. 401 U.S. 395 (1971); Williams v. Illinois, 399 U.S. 235 (1970). This illustrates the force of the equality principle, but as Justice Harlan argued in those cases, the Court has been unwilling to extend their equality rationale to include other wealthbased disadvantages. See, e.g., Williams v. Illinois, 399 U.S. at 259 (Harlan, J., concurring in the result); Griffin v. Illinois, 351 U.S. at 29 (Harlan, J., dissenting). And it seems apparent by now that the inequality principle that was articulated in the access cases is much more akin to a "minimality" theory for very specific and narrowly confined services. $C f$. San Antonio Independent School Dist. v. Rodriguez, 411 U.S. 1 (1973). For a good articulation of the minimality concept, see Michelman, Foreword, supra note 173; Michelman, Welfare Rights, supra note 173.

241. Of course what constitutes "adequate" justification is the critical question. See generally Gunther, The Supreme Court 1971 Term-Foreword: In Search of Evolving Doctrine on a Changing Court: A Model for a Newer Equal Protection, 86 HARv. L. REv. 1 (1972).

242. The definition of the "benefit" is often an issue itself. If access to the dialysis machine is the definition of the "given benefit," then clearly our hemophiliac is not requesting equal access to it. On the other hand, if the benefit is defined as access to life-saving medical resources, then our hemophiliac is demanding not to be excluded from that "given benefit."

243. See Ely, Legislative and Administrative Motivation in Constitutional Law, 79 YALE L.J. 1205, $1224(1970)$.

244. In certain areas-notably where economic or social welfare issues are at stake-the courts take a restrained and deferential reviewing posture. See, e.g., Usery v. Turner Elkhorn Mining Co., 428 U.S. I (1976) (upholding black lung program). For example, governmental subsidy of oats rather than barley may displease the barley farmer but would be upheld by a court as a rational legislative choice. On the other hand, the posture and the outcome would be different if the legislature chose to subsidize Caucasian barley farmers but not other farmers. The distinction would fail because the burden of justification-a showing of necessity to promote a compelling state interest-would be much more difficult to sustain. Compare Shapiro v. Thomp- 
How does a court determine whether persons allegedly disadvantaged by a governmental system of classification are "similarly situated"? In the present context, is it reasonable to conclude that the appropriate category for analysis is "people who have death-producing illnesses but for which there is an extraordinarily expensive treatment"? ${ }^{245}$ If it be agreed that such a categorization is appropriate, then Mr. Jones would argue that as a hemophiliac he is situated similarly to those who have kidney failure and put government to the test of justifying ostensibly unevenhanded funding allocation decisions. ${ }^{246}$

What will constitute a legitimate and sufficient defense to such a claimed inequality? Can the state argue that since resources are finite, and allocative choices must necessarily be made, that it is reasonable to define kidney patients as a class and choose them rather than hemophilia victims as recipients of government largesse?247 What degree of deference must courts give to these allocative decisions? ${ }^{248}$

son, 394 U.S. 618 (1969), with Dandridge v. Williams, 397 U.S. 471 (1970). The subsidy of Caucasian barley farmers raises an issue of defining the "benefit" and the benefited class, a problem discussed in note 242 supra. Consider, for example, who would have standing to challenge the legislative classification. Would black oat farmers be able to raise the claim or only black barley farmers? What remedy would be appropriate-ordering subsidies for no farmers, all barley farmers, or all farmers? The answer to the standing question will depend on whether the black oat farmer has a constitutional grievance, see Singleton v. Wulff, 423 U.S. 106, 121 (1976) (Stevens, J., concurring), and that will, in turn, depend on the Court's perception of what the "given benefit" of the government program is.

245. See notes 242 \& 244 supra. A similar problem arises where legislative classifications purport to serve as proxies for some other, legislatively determined eligibility criterion. For example, a durational residency requirement for voting is an imprecise attempt to prevent fraud and assure that voters are knowledgeable. It establishes an objective rule that, in effect, conclusively presumes all newcomers to be either ignorant or deceitful. See Dunn v. Blumstein, 405 U.S. 330 (1972). In other situations, eligibility criteria may be set as rough surrogates for some overriding legislative purpose. Thus, a school board may require that pregnant women cease work after a predetermined number of months of pregnancy as an approximation of ability to work, even though many women can adequately carry on their work until later in their pregnancy. Where the Court has seen a supervailing legislative purpose, it has carefully examined the surrogate classification, invalidating the mandatory pregnancy leave rule, for example. Cleveland Board of Educ. v. LaFleur, 414 U.S. 632 (1974).

In other cases, the Court has concluded that the legislative classification represented a substantive policy choice, not a shorthand for some other legislative purpose, and sustained the classification. See, e.g., Weinberger v. Salfi, 422 U.S. 749 (1975); Usery v. Turner Elkhorn Mining Co., 428 U.S. 1 (1976) (upholding black lung program). Similarly, the Court in Mathews v. Lucas, 427 U.S. 495 (1976), sustained a complicated statutory scheme that ostensibly discriminated against some illegitimate children. Finding a supervailing legislative purpose-dependency at death-the Court concluded that the statutory presumptions were reasonable as surrogates to further that purpose, though arguably ir rational if seen as substantive policy decisions. See generally text at section II.B.2.c. infra.

246. See generally Ely, supra note 243.

247. See Geduldig v. Aiello, 417 U.S. 484 (1974): Dandridge v. Williams, 397 U.S. 471 (1970).

248. Suppose the government supports its decision by demonstrating that the kidney program is more effective and efficient in saving lives on a cost per life basis, properly accounting for likelihood of success, rehabilitation, future productivity and so forth. Would it be appropriate for Jones's lawyer then to argue that it would be most cost effective, on the same criterion, to invest in 
Courts have applied varying tests to determine what state justifications of uneven treatment will be legitimate under the equal protection clause and what the state's burden will be. Until 1972, the Court generally applied a two-tier standard. ${ }^{249}$ In general, the test was that enunciated by Chief Justice Warren in the Sunday Closing Cases: ${ }^{250}$

\begin{abstract}
Although no precise formula has been developed the Court has held that the Fourteenth Amendment permits the States a wide scope of discretion in enacting laws which affect some groups of citizens differently than others. The Constitutional safeguard is offended only if the classification rests on grounds wholly irrelevant to the achievement of the State's objective. State legislatures are presumed to have acted within their constitutional power despite the fact that, in practice, their laws result in some inequality.
\end{abstract}

That traditional, or relaxed, standard of review clearly gives considerable leeway to states when they categorize, and reflects a restrained role for the Court.

The Court in the 1960s found this modest role increasingly confining, especially as its members became more inclined toward an interventionist judicial approach. Accordingly, this traditional rationality standard was replaced in two broad categories of cases. ${ }^{251}$ Where the Court found an interest involved that it deemed "fundamental," or where the basis of the classification was a category found to be "suspect," the Court developed a more stringent reviewing standard, allowing much less flexibility for the state. Among the interests the Court identified as fundamental were voting, ${ }^{252}$ travel, ${ }^{253}$ marriage,${ }^{254}$ procreation, ${ }^{255}$ free exercise of religion, ${ }^{256}$ speech, ${ }^{257}$ and politi-

a hemophilia program rather than spend money on maintaining prisons for those serving life for what might be capital crimes? Or that other health programs are similarly poor public choices, based on the government's own criteria? What remedy would Jones seek and how would it be implemented? These budget decisions will eventually be thrust on courts in certain circumstances. See, e.g., Wyatt v. Stickney, 344 F. Supp. 373, 377-78 (M.D. Ala. 1972).

249. Gunther, supra note 241. An exception not mentioned by Professor Gunther is Turner $v$. Fouche, 396 U.S. 346, 363-64 (1970), where the Court invalidated a law which made those who did not own real property ineligible to serve as school board members. See also Massachusetts Board of Retirement v. Murgia, 427 U.S. 307, 317 (1976) (Marshall, J., dissenting).

250. McGowan v. Maryland, 366 U.S. 420, 425-26 (1961).

251. See generally Note, Developments in the Law: Equal Protection, 82 Harv. L. Rev. 1065 (1969).

252. See Dunn v. Blumstein, 405 U.S. 330 (1972): Kramer v. Union Free School Dist. No. 15, 395 U.S. 621 (1969); Williams v. Rhodes, 393 U.S. 23 (1968); Harper v. Virginia Board of Elections, 383 U.S. 663 (1966).

253. Dunn v. Blumstein, 405 U.S. 330 (1972); Oregon v. Mitchell, 400 U.S. 112,281 (1970) (opinion of Stewart, J.); Shapiro v. Thompson, 394 U.S. 618 (1969); United States v. Guest, 383 U.S. 745 (1966).

254. Boddie v. Connecticut, 401 U.S. 371 (1971); Loving v. Virginia, 388 U.S. I (1967).

255. Cleveland Board of Educ. v. LaFleur, 414 U.S. 632 (1974); Skinner v. Oklahoma, 316 U.S. 535 (1942). $C f$. Eisenstadt v. Baird, 405 U.S. 438 (1972).

256. Wisconsin v. Yoder, 406 U.S. 205 (1972); Sherbert v. Verner, 374 U.S. 398 (1964).

257. Chicago Police Dep't v. Moseley, 408 U.S. 92 (1972). But see Young v. American Mini Theatres, Inc., 427 U.S. 30 (1976) (upholding Detroit zoning ordinance limiting the location of adult cinemas and bookstores). 
cal association. ${ }^{258}$ Classifications labeled suspect ${ }^{259}$ were race $^{260}$ and alienage. ${ }^{261}$ Once a case fit into either the "fundamental interests" or "suspect classification" 262 mold, the Court entered into a much more searching scrutiny. ${ }^{263}$ Rather than accepting any rational basis for the classification, the Court importantly made two further inquiries: (a) How important is the governmental interest that is being promoted? (b) Are the means selected to achieve the policy objective least intrusive on the fundamental personal interests identified? The Court would, then, sustain a disadvantageous ${ }^{264}$ classification in these circumstances only where the goals themselves were of overriding importance and where the means selected were narrowly tailored to the ends. ${ }^{265}$ The Court's verbal formula for this stricter standard of review was that the exclusions resulting from the classification must be "necessary to promote a compelling state interest." 266

Predictably, with the changing composition of the Supreme Court ${ }^{267}$ there

258. Buckley v. Valeo, 424 U.S. 1 (1976); Cousins v. Wigoda, 419 U.S. 477 (1975); Williams v. Rhodes, 393 U.S. 23 (1968).

259. The Court has refrained from labeling either sex or illegitimacy suspect, even though they seem disfavored. See Frontiero v. Richardson, 411 U.S. 677 (1973); Mathews v. Lucas, 427 U.S. 495 (1976); text at section II.B.3. infra.

260. Loving v. Virginia, 388 U.S. 1 (1967); Brown v. Board of Educ., 347 U.S. 483 (1954); Korematsu v. United States, 323 U.S. 214 (1944).

261. See note 385 infra.

262. This concept derives from Justice Stone's well-known foøtnote four in United States $v$. Carolene Products Co.

There may be narrower scope for operation of the presumption of constitutionality when legislation appears on its face to be within a specific prohibition of the Constitution, such as those of the first ten amendments, which are deemed equally specific when held to be embraced within the Fourteenth. ...

.. [P]rejudice against discrete and insular minorities may be a special condition, which tends seriously to curtail the operation of those political processes ordinarily to be relied upon to protect minorities, and which may call for a correspondingly more searching judicial inquiry.

304 U.S. 144, 152-53 (1938).

263. Classifications that utilize recent exercise of fundamental interests as a principle of classification are often given the same effect as those labeled "suspect," or otherwise disfavored. See Shapiro v. Thompson, 394 U.S. 618, 655 (1969) (Harlan, J., dissenting). This is probably the most rational approach toward understanding the Court's use of the "penalty" concept. See note 316 infra; Brief for Appellee, Dunn v. Blumstein, 405 U.S. 330 app. (1972). But see McCoy, Recent Equal Protection Decisions-Fundamental Right to Travel or "Newcomers" as a Suspect Class?, 28 VAND.

L. REV. 987 (1975).

264. Three terms warrant classification here. Disadvantageous classifications are simply those that treat some groups differently than others. Typically, these must be justified by some appropriate rationale. Suspect classifications are those that trigger strict judicial scrutiny. Disfavored classifications (e.g., gender) have not been fully accorded suspect status, but the Court has been more searching in review than under traditional, relaxed standards.

265. The classification must be precise, Dunn v. Blumstein, 405 U.S. at 343; and where alternatives to the fulfillment of the state interest exist, the state must choose the "less drastic means," Shelton v. Tucker, 364 U.S. 479, 488 (1960).

266. Dunn v. Blumstein, 405 U.S. at 337; Kramer v. Union Free School Dist. No. 15, 395 U.S. 621,627 (1969); Shapiro v. Thompson, 394 U.S. 618, 634 (1969).

267. In his first term, President Nixon appointed four members to the Court-Chief Justice 
came a stiffening to the expansion of interests labeled fundamental and a reluctance to augment the list of classifications deemed suspect. ${ }^{268}$ The Court rejected such interests as welfare, ${ }^{269}$ housing, ${ }^{270}$ and education ${ }^{271}$ from the inner circle $^{272}$ and made it clear that no longer would interests be added based on the Court's perception of "relative societal significance," 273 unless implicitly or explicitly guaranteed by the Constitution. ${ }^{274}$ With respect to suspect classifications, the Court has waffled on such classificatory bases as illegitimacy ${ }^{275}$ and gender, ${ }^{276}$ giving substantial scrutiny in these situations ${ }^{277}$ but refraining from applying the label suspect. As for wealth, once thought a prime candidate for suspect status, ${ }^{278}$ the Court has clearly expressed its unwillingness to accord it that special status, except in those rare situations, alluded to earlier, where impecuniousness would result in total exclusion from basic, governmentally monopolized services. ${ }^{279}$

Burger and Justices Blackmun, Powell, and Rehnquist. During the 1968 presidential election campaign, Mr. Nixon made Supreme Court appointments a major issue. Two of his nominations (Judges Haynsworth and Carswell) were rejected by the Senate. On the confirmation controversy see R. HARris, Decision (1971).

268. See, e.g., San Antonio Independent School Dist. v. Rodriguez, 411 U.S. 1, 28, 33-34 (1973); Lindsey v. Normet, 405 U.S. 56, 74 (1972).

269. Jefferson v. Hackney, 406 U.S. 535 (1972); Dandridge v. Williams, 397 U.S. 471 (1970).

270. Lindsey v. Normet, 405 U.S. 56 (1972).

271. San Antonio Independent School Dist. v. Rodriguez, 411 U.S. 1 (1973).

272. Coons, Clune, and Sugarman employ the term "inner circle" to refer to those "cases singled out upon substantive grounds for special scrutiny." Coons, Clune, \& Sugarman, Educational Opportunity: A Workable Constitutional Test for State Financial Structures, 57 CaLIF. L. REv. 305, 346 (1969).

273. San Antonio Independent School Dist. v. Rodriguez, 411 U.S. 1, 33 (1973).

274. Id. at 33-34. The voting rights cases are an anomaly in light of Rodriguez; the right to vote is nowhere mentioned explicitly in the Constitution, and has been held not guaranteed as a privilege and immunity of citizenship. Minor v. Happersett, 88 U.S. (21 Wall.) 162, 178 (1875). The Court simply asserts that the "Constitutional underpinnings of the right to equal treatment in the voting process can no longer be doubted," 411 U.S. at $34 \mathrm{n} .73$, even though, as Justice Marshall points out, no source for that right is found. 411 U.S. at $110 \mathrm{n} .60$ (Marshall, J., dissenting).

275. Compare Jimenez v. Weinberger, 417 U.S. 629 (1974) and Gomez v. Perez, 409 U.S. 535 (1973) and Weber v. Aetna Cas. \& Sur. Co., 406 U.S. 164 (1972) and Levy v. Louisiana, 391 U.S. 68 (1968), with Mathews v. Lucas, 427 U.S. 495 (1976) and Labine v. Vincent, 401 U.S. 532 (1971). See also Trimble v. Gordon, 97 S. Ct. 1459, 1463-64 (1977).

276. In Frontiero v. Richardson, 411 U.S. 677 (1973), four justices, including Justice Douglas, found gender to be a suspect classification. However, in Kahn v. Shevin, 416 U.S. 351 (1974), Justice Douglas, writing for the majority, apparently retreated from his position in Frontiero, permitting the state to classify on the basis of sex to the benefit of women on the ground that such classification was "benign."

277. See, e.g., Weinberger v. Wiesenfield, 420 U.S. 636 (1975); Reed v. Reed, 404 U.S. 71 (1971); $f f$. Schlesinger v. Ballard, 419 U.S. 498 (1975). The Court has apparently reached consensus on an intermediate standard of review in gender-based classification cases. See Craig v. Boren, 429 U.S. 190, 197 (1976) ("[C]lassifications by gender must serve important governmental objectives and must be substantially related to achievement of those objectives.")

278. See McDonald v. Board of Election Comm'rs, 394 U.S. 802 (1969); Harper v. Virginia Board of Elections, 383 U.S. 663 (1966).

279. See text at section II.A. supra. 
Dissatisfaction with the consequences of strict review ${ }^{280}$ and with the rigidity of the two-tier approach have led to both erosion of the stricter standard of review ${ }^{281}$ and to more rigorous application of the rationality notion. ${ }^{282}$ For example, in Bullock $v$. Carter, ${ }^{283}$ in which the Court held a high candidate filing fee unconstitutional, Chief Justice Burger purported to apply a strict standard, which he articulated as follows: The law must be closely scrutinized and found reasonably necessary to the accomplishment of legitimate state objectives. $^{284}$ In this formulation, the necessity element is modified and the "compelling" interest requirement becomes the less stringent "legitimate" objective standard. Similarly, in some cases purporting to apply a traditional test, the Court's review has had more "teeth," ${ }^{285}$ especially reflected in the unwillingness of the justices to dig up conceivable (though often far-fetched) ${ }^{286}$ statutory objectives, to which the means employed were rationally related. ${ }^{287}$ While the Court majority has not openly acknowledged the erosion of the strict two-tier analysis, ${ }^{288}$ it is nevertheless clear that in at least some situations the Court is exercising more than the minimal scrutiny it professes. ${ }^{289}$

\section{The Effect of Differing Standards of Review}

What is the significance of this debate over appropriate constitutional standards for justifying uneven treatment? For our purposes here, the primary consequence is the impact courts will have on resource allocation decisions.

280. Chief Justice Burger once said "[s]o far as I am aware, no state law has ever satisfied this seemingly insurmountable standard, and I doubt one ever will, for it demands nothing less than perfection." Dunn v. Blumstein, 405 U.S. 330, 363-64 (1972) (dissenting opinion). This is no longer true, as the Court has defined the "compelling" point as viability in the abortion case, Roe v. Wade, 410 U.S. 113 (1973), and has found the standard complied with in the ballot access area. See American Party of Texas v. White, 415 U.S. 767 (1974); Storer v. Brown, 415 U.S. 724 (1974).

281. Bullock v. Carter, 405 U.S. 134 (1972)

282. Eisenstadt v. Baird, 405 U.S. 438 (1972); Reed v. Reed, 404 U.S. 71 (1971). See generally; Blumstein. The Supreme Court and Voter Eligibility, in Issues of Electoral Reform (R. Carlson ed. 1974); Guncher, supra note 241.

283. 405 U.S. 134 (1972).

284. Id. at 144 (emphasis added).

285. G. Gunther, Constitutional Law 770 (1975), uses the term "minimal scrutiny "with bite." "

286. E.g., Railway Express Agency v. New York City, 336 U.S. 106 (1949); Kotch v. Board of River Pilot Comm'rs, 330 U.S. 552 (1947).

287. See, e.g., Eisenstadt v. Baird, 405 U.S. 438 (1972), where Justice Brennan limited his analysis to the articulated rationales.

288. E.g., San Antonio Independent School Dist. v. Rodriguez, 411 U.S. 1 (1973). See also Massachusetts Retirement Board v. Murgia, 427 U.S. 307, 317 (1976) (Marshall, J., dissenting).

289. This is primarily true with classifications based on gender and illegitimacy. E.g., Trimble v. Gordon, 97 S. Ct. 1459 (1977); Weinberger v. Wiesenfield, 420 U.S. 636 (1975); Jimenez v. Weinberger, 417 U.S. 629 (1974); Frontiero v. Richardson, 411 U.S. 677 (1973). 
a. The Rationality Standard: Restrained Review

Under the minimal scrutiny of the rationality standard, the Court has made it clear that it will not interfere actively with governmental resource allocation preferences. For example, in Dandridge $v$. Williams, ${ }^{290}$ a constitutional challenge to Maryland's Aid to Families with Dependent Children (AFDC) Program, the Court sustained a maximum welfare grant of $\$ 250$ per month per family, regardless of the family's size. Beyond a certain number of children in a family, the state chose to eliminate any further welfare allowance. Plaintiffs deemphasized the unitary nature of the family and stressed the importance of each child as an autonomous individual. They argued that the most recently born children (beyond the maximum) were discriminated against unfairly since they were denied governmental benefits even though situated similarly to their older siblings. The Court concluded that the question was one in the "area of economics and social welfare"291 and, therefore, applied restrained review. The Court was well aware of the element of hardship involved in allocating welfare funds, but it was distinctly disinclined to involve itself in the "intractable economic, social, and even philosophical problems presented by public welfare assistance programs." ${ }^{292}$ While acknowledging that states had procedural obligations to meet in determining questions of eligibility" for welfare programs, the Court would not "second-guess state officials charged with the difficult responsibility of allocating limited public welfare funds among the myriad of potential recipients." ${ }^{294}$

Thus, in cases involving difficult resource allocation issues, the Court seems likely to grant considerable deference to political choices made by politically accountable officials. ${ }^{295}$ Along this line, the Court by a narrow margin upheld a Texas provision which granted a lower percentage of defined "need" to AFDC recipients than to beneficiaries of other categorical assistance programs. ${ }^{296}$ The Court found the state's choice of preference for the elderly rather than the young reasonable given the elderly's relative lack of adaptability and hope. ${ }^{297}$

When applying the restrained standard, the Court will typically accept as

290. 397 U.S. $471(1970)$.

291. Id. at 485 .

292. Id

293. Id. at 483. See also Goldberg v. Kelly, 397 U.S. 254 (1970).

294. 397 U.S. at 487.

295. See, e.g., Weinberger v. Salfi, 422 U.S. 749 (1975); Geduldig v. Aiello, 417 U.S. 484 (1974); Jefferson v. Hackney, 406 U.S. 535 (1972). See also Maher v. Roe, 45 U.S.L.W. 4787,4791 (U.S. June 20, 1977) ("Indeed, when an issue involves policy choices as sensitive as those implicated by public funding of nontherapeutic abortions, the appropriate forum for their resolution in a democracy is the legislature.")

296. Jefferson v. Hackney, 406 U.S. 535 (1972).

297. Id. at 549 . 
given the "macro" allocation decisions. ${ }^{298}$ The Court will allow the responsible government officials to claim that the size of the welfare pie, for instance, is fixed and that allocation priorities must be set within those politically determined financial limits. As a result, in Geduldig $v$. Aiello, the Court refused to require the state of California to include maternity as a covered disability in the state disability benefit program. ${ }^{299}$ The evidence showed that inclusion of pregnancy-related disabilities would add considerably more expense to the existing program; inclusion of pregnancy in a more comprehensive scheme, therefore, "would inevitably require state subsidy, a higher rate of employee contribution, a lower scale of benefits for those suffering insured disabilities, or some combination of these measures."300 Finding no impermissible gender-based classification, the Court concluded that the matter called for the Dandridge variety of restrained review; applying that standard, the Court refused to require the state to water down benefits or to generate more funds for the program, either by general subsidy or increased taxation of employees. ${ }^{301}$

Under a restrained review, the Court would likely sustain a governmental program that funded kidney dialysis but excluded treatment for hemophilia. Applying the Dandridge or Geduldig rationale, the Court would accept the macro resource allocation decision of the legislative branch, deferring to its designation of benefited classes and its choice among allocative alternatives. If $\mathrm{Mr}$. Jones could persuade a court that the government's decision as to allocation preferences directly affected his life-a "fundamental interest" 302 under the fourteenth amendment-then the outcome might be quite different.

298. The macro decision here is the defining of the class. Determining who falls within that class is a micro decision. See discussion of micro and macro choices in other contexts, supra notes $133 \& 134$.

299. 417 U.S. 484 (1974).

300. Id. at 494-96.

301. Id. Accord, General Electric Co. v. Gilbert, 429 U.S. 125 (1976).

302. Because of the fundamental importance of voting in a democratic society, the Court has held states to a strict standard of review where statutes selectively distribute the franchise. Dunn v. Blumstein, 405 U.S. 330 (1972); Kramerv. Union Free School Dist. No. 15, 395 U.S. 621 (1969). As the Court has so often stated, voting is fundamental because it is preservative of other rights. Reynolds v. Sims, 377 U.S. 533 (1964); Yick Wo v. Hopkins, 118 U.S. 356 (1886). The interest in preservation of life is explicitly mentioned in the fourteenth amendment, one of the criteria for inclusion in the inner circle of fourteenth amendment protection. San Antonio Independent School Dist. v. Rodriguez, 411 U.S. 1, 33-35 (1973). And, as in the voting cases, the threat is one of absolute deprivation-i.e., death. Compare Rosario v. Rockefeller, 410 U.S. 752 (1973), with Kusper v. Pontikes, 414 U.S. 51 (1973). In Rosario, the Court sustained an unusually lengthy registration cut-off for voting in party primaries, distinguishing Dunn $v$. Blumstein on the ground that the New York law "did not absolutely disenfranchise the class to which the petitioners belong." 410 U.S. at 757. In Pontikes the Court struck down a statute prohibiting a person from voting in a primary election of one party if he or she had voted in another party's primary within the preceding twenty-three months. The law challenged in Rosario simply required diligence on the part of the voter in registering, while the law involved in Pontikes locked the person into one party, thereby absolutely depriving him or her of an opportunity to exercise the right to change party affiliation. 


\section{b. The Compelling Interests Standard: Strict Scrutiny}

Were the Court to accept the fundamental interests rationale, it would be led to a more intense degree of scrutiny, thereby no longer accepting the basic societal allocation decision as immutable. Where the "compelling interest" formula is applied, the Court will require the state to demonstrate an overriding interest, and lack of funds has not been deemed sufficient to meet this burden. ${ }^{303}$

If such an approach were used, the Court could simply reject the basis on which the classification is drawn and require admission of the excluded (hemophiliacs) along with the favored (kidney patients) to the advantaged class (people who have death-producing illness for which an extraordinarily expensive treatment exists) despite the fiscal impact. ${ }^{304}$

The same stricter standard of review would apply if the basis of the classification were found to be suspect (e.g., race). In those situations, the Court is unwilling to allow government to draw distinctions upon such characteristics, even if the judicial action has significant resource allocation consequences. Evidence of statistical probabilities will be insufficient in suspect classification cases to justify the distinction. ${ }^{305}$ More precise means of drawing distinctions must be found. ${ }^{306}$ Both the nature of the interest affected and the character of the classification can bring about this more stringent standard. ${ }^{307}$

Judicial acceptance of the strict scrutiny approach in a case ${ }^{308}$ brought by a hemophiliac would be an invitation to others with diseases whose treatment is

303. See, e.g. Shapiro v. Thompson, 394 U.S. 618 (1969). Courts have had no problems in ordering the expenditure of an additional three million dollars for busing, Brewer v. School Board, 456 F.2d 943, 947 (4th Cir. 1972), nor in ordering the purchase of thirty-eight additional school buses to enable the school system to comply with the court's remedial plan. Eaton v. New Hanover County Board of Educ. 459 F.2d 684, 686 (4th Cir. 1972). See also Milliken v. Bradley, 45 U.S.L.W. 4873 (U.S. June 27, 1977).

304. Cf. Shapiro v. Thompson, 394 U.S. 618 (1969). See generally Vlandis v. Kline, 412 U.S. 441 (1973).

305. In response to an argument that a subsidy equal to the probable expenditure of a private religious school on maintenance and repair was sufficient assurance that the state expenditure was secular (for health and safety of students) rather than religious, the Court stated that "statistical judgment will not suffice as a guarantee that state funds will not be used to finance religious education." Committee for Pub. Educ. \& Religious Liberty v. Nyquist, 413 U.S. 756,778 (1973).

306. See generally Ely, supra note 243 , at 1249 n.134.

307. Dunn v. Blumstein, 405 U.S. 330, 335 (1972); Williams v. Rhodes, 393 U.S. 23,30 (1968).

308. Where the courts perceive positive reform or remedial action in progress, they seem less likely to apply strict scrutiny. Thus the Court applied less stringent standards of review where a challenged school financing scheme was seen "to ameliorate the differences in levels of expenditures," although inequality remained. San Antonio Independent School Dist. v. Rodriguez, 411 U.S. 1, 55 (1973). Similarly, the Court took a restrained stance when faced with a challenge to Illinois absentee ballot provisions. It found "a consistent and laudable state policy of adding ... groups to the absentee coverage," and upheld the state's failure to extend absentee balloting opportunities to jail inmates awaiting trial: "That Illinois has not gone still further . . should not render void its remedial legislation." McDonald v. Board of Election Comm'rs, 394 U.S. 802, 811 (1969); cf. O'Brien v. Skinner, 414 U.S. 524 (1974); notes 179, 302 supra. 
very expensive to seek admission to the covered class or judicial redefinition of the beneficiary classification. ${ }^{309}$ Although the Court has carefully eschewed adoption of a review posture with such far-reaching consequences in cases clearly involving allocation of social services funds, ${ }^{310}$ it appeared for a time more receptive to cases it perceived as raising primarily eligibility (micro) questions, despite the ultimate potential impact on macro decisions. ${ }^{311}$ Consider Shapiro $v$. Thompson. ${ }^{312}$ There the state of Connecticut imposed a oneyear waiting period (a durational residency requirement) on new residents before they became eligible for welfare benefits. Although its rationale is still very much the subject of debate,$^{313}$ the Court concluded that a durational residency requirement impermissibly penalized the fundamental interest in interstate travel.

There are two relevant elements of Shapiro for our discussion. First, the state argued that a one-year waiting period was a reasonable device to assure that newcomers were bona fide residents of the state. The Court understood the state classification system to distinguish between residents and nonresidents, and the waiting period could be viewed as a technique for assuring that only those actually qualified as residents would secure welfare benefits. Seeing this as an eligibility question at the micro level, the Court reasoned that this procedure of identifying bona fide residents was too imprecise since many newcomers were legitimate residents of the state, and no waiting period is necessary to establish residency. This facet of Shapiro is concerned with providing bona fide residents an opportunity to demonstrate, on some individualized basis, that they fall within the class of bona fide (albeit new) residents, the class defined by the state as qualified for welfare benefits. ${ }^{314}$

The second element of Shapiro assumes that the classification made by the state-new versus longtime residents-was intended only as a means of allocating scarce welfare resources. That is, Connecticut had a given welfare budget which it chose to divide in larger shares among longtime residents to the entire exclusion of newcomers. Viewed this way, Shapiro resembles the

309. This slippery slope on which the Court would find itself discourages holding in favor of our hemophiliac. The Court has expressed its reluctance to use strict scrutiny in reviewing social welfare legislation. In Weinberger $\%$. Salfi it rejected a request to apply a form of strict scrutiny to an eligibility requirement on the ground that such an approach "would turn the doctrine into a virtual engine of destruction for coundess legislative judgments which would have heretofore been thought wholly consistent with the Fifth and Fourteenth Amendments." 422 U.S. 749, 772 (1975).

310. Jefferson v. Hackney, 406 U.S. 535 (1972); Dandridge v. Williams, 397 U.S. 471 (1970)

311. E.g., United States Dep't of Agriculture v. Murry, 413 U.S. 508 (1973). See generally Note, Irrebutable Presumptions: An Illuson Analysis, 27 Stan. L. Rev. 449 (1975); Note, The Irrebutable Presumption Doctrine in the Supreme Court, 87 Harv. L. Rev. 1534 (1974); Note, The Conclusive Presumption Doctrine: Equal Process or Due Protection?, 72 МICH. L. Rev. 800 (1974).

312. 394 U.S. 618 (1969).

313. See, e.g., McCoy, supra note 263.

314. Cf. Vlandis v. Kline, 412 U.S. 441,452 (1973). 


\section{subsequently decided Dandridge (maximum welfare grant) and Geduldig (pregnancy not a covered disability) cases. The Court rejected the state's argument ${ }^{315}$ because the waiting period constituted an unwarranted "penalty" on the exercise of the constitutionally protected ("fundamental") interest in interstate travel. ${ }^{316}$}

315. The Court rejected as well a state argument that the challenged classification be sustained as distinguishing between new and old residents on the basis of prior tax contributions. Such an argument proved too much, for it could similarly justify apportionment of all government services to its citizens on the basis of tax contributions. 394 U.S. at 632-33.

316. The "penalty" concept has not been one of the Court's more lucidly explained notions, but it seems to reflect an unwillingness to permit government to distribute social services, or otherwise classify individuals, solely in terms of the recent exercise of a constitutionally protected fundamental interest. See, e.g. Maher v. Roe, 45 U.S.L.W. 4787,4790 n.8 (U.S. June 20, 1977). In the voter durational residency case, the Court made it clear that actual or potential deterrence to travel was not a necessary component of the penalty on interstate travel. Dunn v. Blumstein, 405 U.S. 330 (1972). The Court used the following example to illustrate the difference between "penalty" and deterrence: A sixteen-year-old person with a driver's license may be deterred from moving to another state where a driver's license will be issued only to eighteen-year olds; however, this rule, which applies to all residents uniformly, would not be an impermissible penalty. Id. at 342 n. 12.

In Blumstein the Court noted that the fundamental interests in voting and travel were affected differently-voting was prohibited entirely for new residents while travel was penalized. Both effects triggered strict scrutiny. Since the Court has acknowledged in the voting context that total deprivations will be treated more strictly than other forms of voting restrictions, see note 302 supra, one can conclude that the penalty concept relies on a subtle admixture of the nature of the interest being exercised (i.e., interstate travel is "fundamental") and the character of the classificatory system itself. It is this latter feature that has many of the elements of the Court's "suspect classification" notion, and the three-judge district court in Blumstein explicitly found the basis of classification suspect. Blumstein v. Ellington, 337 F. Supp. 323, 329 (M.D. Tenn. 1970). See also Shapiro v. Thompson, 394 U.S. 618, 660 (1969) (Harlan, J., dissenting).

The importance of the character of classification is highlighted by the decision in Harman $\mathbf{v}$. Forssenius, 380 U.S. 528 (1965), in which the Court held invalid as a penalty a Virginia law that allowed federal voters to qualify either by paying a poll tax or by filing a certificate of residence six months before the election. Strict scrutiny can be explained not because there was an absolute deprivation of a constitutionally protected right (to vote in federal elections without payment of a poll tax under the twenty-fourth amendment) but because access was penalized (handicapped) upon the exercise of that protected right.

The question remains whether the "penalty" concept is not at all dependent on the exercise of some fundamental interest (e.g., travel), but rather that a straight suspect classification has been implicitly (though not explicitly) established by the Court, based not on the exercise of a basic liberty but on characteristics inherent in the class itself. Implausible as it seems, one commentator has argued that "newcomers" have been designated a suspect category, totally apart from their having recently exercised a fundamental interest (travel). See McCoy, supra note 263.

This is an extremely doubtful explanation of the Court's decisions given the emphasis in the opinions on the fundamental nature of the interest in travel. Indeed, Justice Stewart expressly distinguished the welfare provision in Dandridge v. Williams, 397 U.S. $471,484 \mathrm{n} .16$ (1970) from that in Shapiro v. Thompson, 394 U.S. 618 (1969), on the ground that the statute in Shapiro penalized the interest in travel. Moreover, the opinion of Justice Stewart, in which Chief Justice Burger and Justice Blackmun joined, in Oregon v. Mitchell, 400 U.S. 112, 281 (1970), relied on the federal interest in protecting interstate travel to justify congressional obviation of state durational residency laws for federal elections. Federal authority was premised on the existence of a federal constitutional interest in protecting travel, not in protecting a suspect class of newcomers. Contrast the rationale for sustaining the application of employment discrimination provisions of title VII of the 1964 Civil Rights Act to state and municipal government. See Fitzpatrick v. Bitzer, 427 U.S. 445 (1976). 
In Shapiro, then, the basis of the resource allocation classification was constitutionally impermissible, even if seen as a macro allocation question, because the characteristic that triggered ineligibility was exercise of a protected fundamental interest. ${ }^{317}$ At the micro level, the use of a waiting period was an imprecise means for assuring that only bona fide residents would receive welfare benefits, and, since the system of classification relied on the recent exercise of a fundamental liberty, the Court decided that a more rigorous standard of review was appropriate. ${ }^{318}$ Whether analyzed at the macro or micro levels, however, the decision in Shapiro was bound to have significant budgetary consequences, expanding the numbers of people who would be able to show eligibility. The Court seemed willing to accept this consequence.

The concern that government should tailor its regulation to individual circumstances, expressed in Shapiro, is striking in cases perceived as turning on eligibility issues. ${ }^{319}$ In Cleveland Board of Education v. LaFleur, the Court held

The newcomers rationale also does not conform to the Court's reticence for establishing new suspect categories. It has refused to so designate gender, see Frontiero v. Richardson, 411 U.S. 677 (1973), and illegitimacy, see Mathews v. Lucas, 427 U.S. 495 (1976), and has even edged away from its position with respect to alienage. Compare Mathews v. Diaz, 426 U.S. 67 (1976) and Hampton v. Mow Sun Wong, 426 U.S. 88 (1976), with Graham v. Richardson, 403 U.S. 365 (1971). But see. Nyquist v. Manclet, 45 U.S.L.W. 4655, $4657-58$ (U.S. June 13, 1977). Furthermore, there are cases outside of the right to travel context that lend doctrinal support to the penalty concept as it relates to the exercise of basic liberties. For example, the Court has held invalid a spoils patronage system for non-policymaking government positions, arguing that classifications based solely on party affiliation (a fundamental right of political association) could not be the basis for employment dismissal, absent strong overriding justifications. Elrod v. Burns, 427 U.S. 347 (1976). See also Baxter v. Palmigiano, 425 U.S. 308, 314-20 (1976); Gardner v. Broderick, 392 U.S. 273 (1968); United States v. Jackson, 390 U.S. 570, 582-83 (1968); Spevack v. Klein, 385 U.S. 511 (1967); Sherbert v. Verner, 374 U.S. 398 (1963). Compare Slochower v. Board of Higher Educ., 350 U.S. 551 (1956), with Nelson v. County of Los Angeles, 362 U.S. 1 (1960) and Lerner v. Casey, 357 U.S. 468 (1958) and Beilan v. Board of Educ., 357 U.S. 399 (1958). The line has not always been straight or clearly discernible, and cases can be found which arguably do not fit neatly into the pattern. See, e.g., Wyman v. James, 400 U.S. 309 (1971). Professor McCoy relies entirely on Johnson v. Robison, 415 U.S. 361 (1974), which upheld the denial of veterans' benefits to conscientious objectors. That case is certainly a slender reed on which to construct an entire theory and in turn dismiss a long line of cases. This is especially true since the Court has never held that conscientious objection, a statutory right, enjoys constitutional protection. See generally Gillette v. United States, 401 U.S. 437, $461 \& \mathrm{n} .23$ (1971). Clearly, the last word on this intriguing concept has not yet been written.

317. There has been some question as to the source of the "right to travel"-whether it is the Commerce Clause, Edwards v. California, 314 U.S. 160 (1941); an aspect of "liberty" under the fifth and fourteenth amendments, Kent v. Dulles, 357 U.S. 116 (1958); a "privilege and immunity" under article IV, section 2, Corfield v. Coryell, 6 F. Cas. 546, 552 (C.C.E.D. Pa. 1823) (No. $3,230)$; a "privilege and immunity" under the fourteenth amendment, Edwards v. California, 314 U.S. 160, 181, 183-85 (1941) (Douglas \& Jackson, JJ., concurring); or a structural inference from the federal system, United States v. Guest, 383 U.S. 745 (1966). See generally Shapiro v. Thompson, 394 U.S. 618,638 n.21 (1969).

318. "Precision of regulation must be the touchstone in an area so closely touching our most precious freedoms." NAACP v. Button, 371 U.S. 415, 438 (1963); see notes 264, 265, 266 supra and accompanying text.

319. See, e.g., Vlandis v. Kline, 412 U.S. 411 (1973). See also United States v. Provident Trust Co., 291 U.S. 272 (1934); Heiner v. Donnan, 285 U.S. 312 (1932). These are due process (conclusive presumption) cases, not decided on equal protection grounds. 
invalid a school board regulation that barred teachers from the classroom five months prior to giving birth. ${ }^{320}$ Finding that different women are able to work for different lengths of time during pregnancy, the Court required the school board to allow an individualized determination of ability to work based on medical evidence.

As in Shapiro, two separable questions arose in LaFleur: (1) Can the school board conclusively presume as an empirical matter that women cannot teach after four months of pregnancy? (2) Can the school board conclude, as a substantive policy determination, that women who are four months pregnant should be barred from the classroom? The Court apparently concluded that the woman's fundamental liberty to bear children precluded exclusion from her government job solely on the basis of her pregnant status-a disadvantageous classification cannot be premised solely on the exercise of a protected basic liberty. ${ }^{321}$ Once the substantive ground of pregnancy qua pregnancy was eliminated as a rationale, it became clear that the rule would stand or fall on medical evidence. In light of the importance the Court has assigned to the interest in childbearing, ${ }^{322}$ the more precise method of determining ability to work-medical evidence-must be permitted. Unlike Shapiro, however, LaFleur did not involve significant resource allocation consequences since instruction activities were to be carried on in any event by substitute teachers; the question was who would do the teaching. ${ }^{323}$

For the problem of valuing life, such requirements for individualized attention $^{\mathbf{3 2 4}}$ may exacerbate the allocative distortions that accompany emphasis on identifiable lives. ${ }^{325}$ It is a safe guess that a formal adjudicatory body de-

320. 414 U.S. 632 (1974).

321. See note 316 supra. The board asserted, among other justifications for the mandatory pregnancy leave provision, that it was saving teachers "from embarrassment at the hands of giggling school children." 414 U.S. at 641 . The Court did not consider this argument and raised it only to show the "less weighty" considerations that may have inspired the regulation. Id. Some attempt at controlling the giggling, e.g., disciplinary action against the gigglers, would probably be required before curtailment of the teacher's employment would be a constitutionally permitted solution to the problem. Cf. Gregory v. Chicago, 394 U.S. 11 l (1969); Tinker v. Des Moines Community School Dist., 393 U.S. 503 (1969).

322. See Planned Parenthood of Cent. Mo. v. Danforth, 428 U.S. 52 (1976); Roe v. Wade, 410 U.S. 113 (1973) (woman in consultation with physician has authority to terminate a pregnancy prior to fetal viability, even where state law prohibits abortion, requires spousal consent, or, for unmarried minors, requires parental consent). See also Maher v. Roe, 45 U.S.L.W. 4787 (U.S. June 20, 1977).

323. Nevertheless, the individualized treatment requirement of the conclusive presumption cases may add significant administrative costs. The court is aware of this and has taken into account the cost of adversarial adjudication in determining due process requirements. See, e.g., Mathews v. Eldridge, 424 U.S. 319,348 (1976).

324. On the respective merits of individualized and rule-based decision making, see Tribe, Structural Due Process, supra note 22, at 283 n.43, 286 n.52.

325. See generally Calabresi, Commentary, supra note 13; G. Calabresi, Tragic Choices, supra note 13.

The capital punishment cases highlight another problem with individualized decision making 
ciding on an individual's eligibility would be more likely to find in favor of qualification where life or death ${ }^{326}$ were in the balance, ${ }^{327}$ especially if macro

where identifiable lives hang in the balance. In Furman v. Georgia, 408 U.S. 238 (1972), the pivotal justices (Stewart and White) were concerned that jury decisions at the micro level could dispense mercy unevenly. This result was found constitutionally unacceptable. The dissenters in Furman, and other critics, noted that the ruling apparently favored a macro decision that curtailed jury flexibility at the micro level. Some states responded to Furman by enacting legislatively determined mandatory death statutes. The Court invalidated these laws because it concluded that some individualized examination of death sentences was constitutionally necessary in view of the stakes involved. Roberts v. Louisiana, 45 U.S.L.W. 4584 (U.S. June 6, 1977); Roberts v. Louisiana, 428 U.S. 325 (1976); Woodson v. North Carolina, 428 U.S. 280 (1976); see note 103 supra. The Court did sustain, however, statutes that established detailed guidance to juries and judges to govern exercise of sentencing discretion in capital cases, a task thought impossible only five years earlier. Compare Gregg v. Georgia, 428 U.S. 153 (1976) and Proffitt v. Florida, 428 U.S. 242 (1976) and Jurek v. Texas, 428 U.S. 262 (1976), with McGautha v. California, 402 U.S. 183 (1971); see note 96 supra.

326. Surely this factor weighed heavily in the Supreme Court's decision to invalidate no-mercy death penalty statutes. See notes 96 and 325 supra.

327. A decision-making body that faces only a "yes/no" eligibility question is likely to perceive an issue differently from one that can capture and reallocate savings and therefore faces an "either/or" choice. See Havighurst \& Blumstein, supra note 1, at 33-34, 50-51. See also note 225 supra and accompanying text.

Even when decision makers have no institutional incentive to say "no," they appear more able to apply hard-nosed eligibility criteria when they face a large volume of applications. For example, recent studies of the Social Security disability program note (1) that administrative adjudication of eligibility has been more stringent than that of the courts, and (2) that Congress has backed the administrators on at least one eligibility issue. See note 233 supra.

A disability insurance claimant must (a) meet a prior work requirement, (b) show a "medical" disability, and (c) evidence total disability. The Social Security Administration (SSA) may determine that since most people will not be disabled by certain injuries or illnesses, it is proper to conclude that they are not "disabling." Professor Robert Dixon found that from the beginning of the disability program through calendar year 1970, the Department of Health, Education, and Welfare (DHEW) was affirmed 232 times (59 per cent) and reversed or had the case remanded 162 times (41 per cent). Dixon, The Welfare State and Mass Justice: $A$ Warning from the Social Security Disability Program, 1972 Duke L.J. 681, 700-01 \& nn.92 \& 93. Professor Lance Liebman has found that DHEW was affirmed in only 62 per cent of the 1971 district court cases. He concludes:

The high reversal rate could be attributed to a difference in institutional perspectives.

The Secretary runs a large program and must have rules. Attempting to implement Congress' clear purpose that benefits be provided only to those persons in fact medically disabled, the Secretary establishes hurdles that make it difficult for someone to qualify solely on the basis of a persistent assertion that he is physically incapable of work or able to work only with great pain. Judges, on the other hand, need not consider the program as a whole or its annual budget. Their inquiry is normally focused on an individual claimant, whose story is often sympathetic, whose perseverance in carrying the case so far is evidence of a sincere claim, and who will not be on Easy Street even if he wins the appeal.

Liebman, supra, note 233 , at 845 .

With respect to the total disability requirement, the courts developed an exception where an admittedly medically disabled worker was in the "job gap." See id. at 850 . In such a case, a worker suffers a medical disability that prevents continuation of pre-injury employment, but he is capable of doing some forms of work. Once an applicant showed a medical disability that made him unable to perform his previous job, the courts required DHEW to show "not only what work the claimant was still capable of performing, but also that obtaining such work was a realistic possibility, and realistic near the claimant's home." $I d$. at 851 . See generally Kerner v. Flemming, $283 \mathrm{~F} .2 \mathrm{~d}$ 916 (2d Cir. 1960). 
resource reallocation were an available option. ${ }^{328}$ This point reemphasizes the significance of procedure ${ }^{329}$ and institutional design ${ }^{330}$ in formulating policy; it also highlights the effect that individualized decision making can have on substantive outcomes. Normally, the factors the Court will consider in determining what procedures are required are (a) the private interest; (b) the risk of imprecision in the system of classification; and (c) the interests of the government, primarily the fiscal and administrative burdens involved. ${ }^{331}$

Courts are accustomed to balancing those factors, but in the valuing life context the process of individualized decision making itself can serve to expand the list of persons eligible for benefits. ${ }^{332}$ Symbolic issues of humanitarian government may intercede, potentially impelling reviewing officials at the "micro" level to undermine in an adjudicatory setting what the legislature previously had determined at the "macro" level. ${ }^{333}$

\section{c. Recent Limits on the Individualized-Treatment Requirement}

Recognition of the potential resource allocation consequences of cases that are framed as micro eligibility questions has more recently led the Court to limit some of the broader implications of the individualized treatment/conclusive presumption line of cases such as LaFleur. In Weinberger $\%$ Salfi ${ }^{\mathbf{3} 4}$ the Court sustained a provision in the Social Security Act that bars those who have been married for less than nine months from collecting benefits upon the death of their spouse. The lower court had found the exclusion to be an

In 1967, Congress disapproved the judicial gloss of the "job gap" cases by amending the statute to require not only inability to perform previous work, but also "any other kind of substantial gainful work which exists in the national economy, regardless of whether such work exists in the immediate area in which he lives, or whether a specific job vacancy exists for him, or whether he would be hired if he applied for work." Social Security Amendments of 1967, 42 U.S.C. $\S 423(\mathrm{~d})(2)(\mathrm{A})(1970)$. Apparently, the courts may be "attempting to exhume Kerner even after its legislative burial." Liebman, supra at 854 n.73. This experience reveals the diverging perspectives faced by decision makers in different institutional roles and settings.

328. See Blumstein, supra note 1 , at 283-85.

329. See generally Zeckhauser, Valuing Lives, supra note 7.

330. See generally G. Calabresi, Tragic Choices, supra note 13. Professor Charles Fried, in discussing the role of rights in medical care, argues that decisions made by administrators and bureaucrats at the "impersonal statistical" level can be more closely attuned to promoting efficiency. He contrasts this mode of decision making with that of a doctor who "breaks faith with his patients" by withholding care within his power to give but which he deems "wasteful." Fried, Rights and Health Care-Beyond Equity and Efficiency, 293 New ENG. J. MEd. 241, 243 (1975). Thus, the institutional architect must be aware of the different issues involved in varying institutional situations-that administrators and bureaucrats "do not have the kind of personal relations with patients that call into being the rights in personal care" and "respecting these rights is not a constraint upon persons at that level." Id. at 244. See also Havighurst, Blumstein, \& Bovbjerg, supra note 33; Blumstein, supra note 1; Havighurst \& Blumstein, supra note 1.

331. Mathews v. Eldridge, 424 U.S. 319,335 (1976).

332. Cf. Liebman, supra note 233 , at 845 .

333. $C f$. notes 327 (discussion of disability insurance program) and 325 (discussion of capital punishment cases) supra; see note 134 supra.

334. 422 U.S. $749(1975)$. 
overly imprecise technique for combating fraud: It provided benefits to those who married for purposes of receiving benefits, where death, though foreseeable at the time of the marriage, was prolonged more than nine months after the wedding, and it disentitled many who married in good faith but whose spouses died suddenly. The Supreme Court, however, saw the duration-ofrelationship standard as an easily administered, objective measure of eligibility and concluded that Congress could rationally believe that underinclusiveness and overinclusiveness in determining eligibility were acceptable costs to pay for an administratively streamlined, objective system. In short, the majority acknowledged the imprecision, but nevertheless found that Congress had sufficient leeway to select an objective method for determining eligibility; the Court would not require more "fairness" at greater expense through a hearing process for individualized treatment. An objective, if imprecise and imperfect, criterion was upheld as a "prophylactic" measure. ${ }^{335}$

The Salfi decision turned at least in part on the absence of protected liberties. ${ }^{336}$ The Court found that the "noncontractual claim to receive funds from the public treasury enjoys no constitutionally protected status," ${ }^{337}$ referring to Dandridge, and concluded that where there is no serinus curtailment of liberties "cognizable under the Constitution," ${ }^{338}$ Congress can impose generalized rules rather than using individualized determinations. ${ }^{339}$

In its emphasis on the absence of constitutionally protected interests and its concern about active judicial involvement in reviewing social welfare program determinations, ${ }^{340}$ Salfi would appear to reflect somewhat of a retrenchment from conclusive presumption cases such as United States Department of Agriculture $\%$ Murry, ${ }^{341}$ which seemed to focus on eligibility issues but which also had significant resource allocation components. In Murry, a divided Court (five to four) invalidated as an impermissible irrebuttable presumption a 1971

335. Id. at 777, 782-83. See also Mourning v. Family Publications Serv., 411 U.S. 356 (1973), where the Court upheld an administrative regulation that required disclosure under the Truth in Lending Act whenever an installment sales contract called for four or more payments. The Court rejected the claim that the four-installment rule erroneously assumed that all such contracts involved a finance charge, finding the "irrebuttable presumption" acceptable as a "prophylactic measure." Id. at 377. The new majority has itself adopted the "prophylactic rule" approach in formulating doctrine. For example, in Imbler v. Pachtman, 424 U.S. 409 (1976), the Court found it in "the broader public interest" to extend prosecutorial immunity to suits for malicious prosecution at the expense of "the genuinely wronged defendant," in order to assure vigorous enforcement of the law by prosecutors who might otherwise fear unwarranted harassment by defendants. Id. at 427 .

336. Weinberger v. Salfi, 422 U.S. at $772-73,785$

337. Id. at 772 .

338. Id at 785 .

339. See note 324 supra.

340. Justice Rehnquist argued that the conclusive presumption rationale "would represent a degree of judicial involvement in the legislative function which we have eschewed except in the most unusual circumstances." 422 U.S. at 773.

341. 413 U.S. 508 (1973). 
Food Stamp Act amendment that excluded an entire household from eligibility if any member over eighteen years of age were taken as a tax dependent by another person not eligible for food stamps. ${ }^{342}$ The Court found that the statutory purpose-preventing abuses of the food stamp program by college students and children from middle class families-was inadequately furthered since the rule was based on a premise often contrary to fact: "the deduction taken for the benefit of the parent in the prior year is not a rational measure of the need of a different household." ${ }^{433}$

The concern of the Court for assuring that persons in "need" under the terms of the act, and otherwise qualified, actually receive benefits, reflects a rejection of Congress's view that the benefits of a broad classification system outweighed the costs in terms of unfairness (over- and underinclusiveness). The Court acted despite the potential fiscal impact and without identifying a constitutionally protected liberty interest. Murry perhaps can be seen as traditional judicial solicitude for procedural protection since "disqualification for food stamp eligibility [was] contingent upon another party's incontrovertible allegation of certain facts." 344 Salfi can be distinguished from Murry on that basis since the duration-of-relationship criterion was directly related to the underlying marriage, which itself served as the basis for Social Security eligibility; and a claim made by a private party who likely has adverse interests may be entitled to less weight than a similar objectively verifiable standard imposed by Congress as a prophylactic, easily administered rule. Accordingly, the inability to rebut such a private claim may be of more constitutional significance.

Nevertheless, the decision in Salfi seems to signal the Court's current perception that micro eligibility questions, in the end, have potentially significant resource allocation consequences that should be decided by legislatures, not courts. ${ }^{345}$ Where issues have been seen as involving the allocation of "limited public welfare funds among the myriad of potential recipients" 346 -macro decisions-the Court has consistently applied the relaxed standard for some time. ${ }^{347}$ It now is likely that more judicial restraint will be exercised, even where issues are pitched as those of micro eligibility, unless the predicates for special solicitude are present: a subject matter entitled to constitutional protection $^{348}$ or a constitutionally disfavored basis of classification. ${ }^{349}$

342. 7 U.S.C. $\$ 2014$ (b) was the challenged section.

343. 413 U.S. at 514 .

344. P. Brest, Processes of Constitutional Decisionmaking 892 (1975).

345. Weinberger v. Salfi, 422 U.S. at 784; $c f$. Mathews v. Lucas, 427 U.S. 495 (1976).

346. Dandridge v. Williams, 397 U.S. 471,487 (1970).

347. See, e.g., Geduldig v. Aiello, 417 U.S. 484 (1974); Williamson v. Lee Optical Co., 348 U.S. 483 (1955); $c f$. Weinberger v. Salfi, 422 U.S. 749.

348. See Weinberger v. Salfi, 422 U.S. at 772-73, 785; Stanley v. Illinois, 405 U.S. 645 (1972).

349. Cleveland Board of Educ. v. LaFleur, 414 U.S. 632 (1974); Vlandis v. Kline, 412 U.S. 441 


\section{Disfavored Classification Characteristics}

Now sensitive to the resource allocation implications of its micro eligibility decisions, the Court may very well be less willing to intercede vigorously where the economic interests of the state are substantially implicated. ${ }^{350}$ Nevertheless, where government draws lines based on disfavored categories of classification, the Court will continue to intervene actively. ${ }^{351}$ This subsection will examine the Court's response to cases-even in the social welfare area -which involve "suspect" or other disfavored criteria of classification.

\section{a. Alienage Classifications}

In Graham $\%$. Richardson, ${ }^{352}$ Justice Blackmun for the majority announced that classifications based on alienage "are inherently suspect and subject to close judicial scrutiny. Aliens as a class are a prime example of a 'discrete and insular' minority-for whom such heightened judicial solicitude is appropriate." ${ }^{553}$ Accordingly, the Court invalidated state laws denying welfare benefits (1) to all noncitizens and (2) to aliens who had not resided in the United States for a total of fifteen years. ${ }^{354}$ Specifically addressing the fiscal impact issue, the Court found that "a concern for fiscal integrity" 355 is not a sufficient justification for the challenged classification, drawing an analogy to the case

(1973); $c f$. Dunn v. Blumstein, 405 U.S. 330 (1972). It is also arguable that the conclusive presumption analysis should be retained more actively where no governmental resource allocation issues are involved. See, e.g., Alber v. Alber, 472 P.2d 321 (Idaho 1970) (conclusive presumption of husband's paternity invalidated when persuasive evidence demonstrated husband was not the father). See note 350 infra. See generally Tribe, Childhood, Suspect Classifications, and Conclusive Presumptions: Three Linked Riddles, supra note 22; Tribe, Structural Due Process, supra note 22.

350. Compare Cleveland Board of Educ. v. LaFleur, 414 U.S. 632 (1974) with Geduldig v. Aiello, 417 U.S. 484 (1974). See discussion of Weinberger v. Salfi, supra notes 334-49 and accompanying text. Courts are less well suited to resolving those resource allocation questions where no basic liberties or disfavored classifications are involved. More judicial intervention might be permitted, however, where the state's economic interests are minimal. See, e.g., Eisenstadt v. Baird, 405 U.S. 438 (1972); Dunn v. Blumstein, 405 U.S. 330 (1972). But see Marshall v. United States, 414 U.S. 417 (1974) (upholding provision of the federal Narcotic Addict Rehabilitation Act that allows some convicted addicts to participate in drug rehabilitative commitment programs in lieu of penal incarceration, but excludes those with two or more prior felony convictions).

351. See, e.g., Hampton v. Mow Sun Wong, 426 U.S. 88 (1976); Memorial Hosp. v. Maricopa County, 415 U.S. 250 (1974); Graham v. Richardson, 403 U.S. 365 (1971).

352. 403 U.S. 365 (1971).

353. Id. at 372. Accord, Nyquist v. Mauclet, 45 U.S.L.W.4655 (U.S. June 13, 1977).

354. The Arizona law held unconstitutional conditioned eligibility for assistance to persons permanently and totally disabled, old age assistance, and assistance to the blind upon citizenship or a fifteen year residence in the United States. This assistance was supported in part by federal grants-in-aid. The Pennsylvania provision that was struck down by the Court dealt with a solely state funded portion of the assistance program, granting aid to those outside the federal guidelines for assistance, but who were "needy" provided they were United States citizens. 403 U.S. at 366-68. In Mathews v. Diaz, 426 U.S. 67 (1976), the Court unanimously upheld a federal law that excluded aliens from Medicare coverage unless they have been admitted for permanent residence and also have resided in the United States for at least five years. The critical distinction between Graham and Diaz was state versus federal regulations of aliens. Id. at 84-85; see note 385 infra. See also Fiallo v. Bell, 97 S. Ct. 1473 (1977).

355. Graham v. Richardson, 403 U.S. at 375. 
invalidating durational residency requirements for the receipt of welfare benefits. $^{356}$

\section{b. Race Classifications}

Race classifications have likewise been held suspect. ${ }^{357}$ Where they have been clearly established by statute, identifying racial classifications as such is straightforward. ${ }^{358}$ But since the school desegregation cases in $1954^{359}$ and their aftermath, ${ }^{360}$ courts have been faced increasingly with the threshold issue of determining when a state-established racial classification exists. ${ }^{361} \mathrm{Un}$ less a governmental agency were to be so overt in its approach as to deprive one group of a benefit (e.g., access to a kidney machine) on an avowedly racial basis-an extremely unlikely prospect-the major question would be to determine whether a racial classification were involved at all.

The Court has not been willing to infer racial classifications solely from data which show unequal impact-at least not in cases seeking to establish substantive constitutional violations. ${ }^{362}$ When California repealed its open housing legislation, the Supreme Court sustained a state court finding that private discrimination in housing was impermissibly advanced ${ }^{363}$ The history of open housing legislation and the debate about the constitutional repealer (California's Proposition 14) persuaded the Court that private race discrimination was implicated; the question for the Court, then, was government's responsibility for this private discrimination.

The California Proposition 14 case reflects the greatest extent to which the Court has gone to find a race classification. Even there, however, the Court noted that the "purpose and intent" was to authorize private racial discrimination in the housing market. ${ }^{364}$ The specific design of the initiative measure was to eliminate a preexisting government barrier to such discrimination, and the Court (split five to four) agreed with the state court that a race classification was involved. ${ }^{365}$

356. Id. at 375-76, citing Shapiro v. Thompson, 394 U.S. 618 (1969).

357. Loving v. Virginia, 388 U.S. I (1964); McLaughlin v. Florida, 379 U.S. 184 (1964); Brown v. Board of Educ., 347 U.S. 483 (1954); Korematsu v. United States, 323 U.S. 214 (1944). 358. See Keyes v. School Dist. No. 1, 413 U.S. 189, 254 (1973) (Rehnquist, J., dissenting).

359. Bolling v. Sharpe, 347 U.S. 497 (1954); Brown v. Board of Educ., 347 U.S. 483 (1954).

360. E.g., Swann v. Charlotte-Mecklenburg Board of Educ., 402 U.S. 1 (1971); Green v. County School Board, 391 U.S. 430 (1968).

361. See, e.g., Village of Arlington Heights v. Metropolitan Housing Development Corp., 429 U.S. 252 (1977); Washington v. Davis, 426 U.S. 229 (1976); Milliken v. Bradley, 418 U.S. 717 (1974); Keyes v. School Dist. No. 1, 413 U.S. 189 (1973).

362. See, e.g., Keyes v. School Dist. No. 1, 413 U.S. 189 (1973); Palmer v. Thompson, 403 U.S. 217 (1971); Whitcomb v. Chavis, 403 U.S. 124 (1971); James v. Valtierra, 402 U.S. 137 (1971); Wright v. Rockefeller, 376 U.S. 52 (1964).

363. Reitman v. Mulkey, 387 U.S. 369 (1967).

364. Id. at 381 .

365. See Black, The Supreme Court, 1966 Term-Foreword: "State Action," Equal Protection, and California's Proposition 14, 81 HARv. L. REv. 69 (1967); cf. Hunter v. Erickson, 393 U.S. 385 (1969) 
In other challenges, ${ }^{366}$ the Supreme Court has refused to allow evidence of effect alone to justify a finding of race classification under the equal protection clause. ${ }^{367}$ The school desegregation cases are revealing in this regard. As the Court has faced non-southern claims of school segregation, it has had to determine whether government had classified by race or whether segregation was the result of private activity. ${ }^{368}$ In Keyes, the Denver case, the Court found that evidence of intent to segregate on the part of government officials was a prerequisite to a finding of racial classification by state action. ${ }^{369}$ And in Milliken, the Detroit case, the Court refused to allow empirical evidence of racial segregation in the surrounding metropolitan area to serve as a predicate for an interdistrict remedy, finding no governmental classification by race beyond the boundaries of the city. ${ }^{370}$

(The Court invalidated a city charter amendment that required a majority vote at a regular election before any ordinance regulating real estate transactions on the basis of race, color, religion, nationality, or ancestry could become effective. The Court found the distinction between enactment of race-based real estate ordinances and other such regulations unconstitutionally discriminatory). Id. at $390-91$.

366. See cases cited at note 362 supra.

367. There is some circuit case law that implies that a showing of substantially disproportionate racial impact suffices to prove a racial classification. For example, in Hawkins v. Town of Shaw, 437 F.2d 1286 (5th Cir. 1971), aff'd on rehearing en banc, 461 F.2d 1171 (1972), the Fifth Circuit found a racial classification based on a detailed showing that unequal provision of municipal services corresponded almost exactly to racial neighborhood compositions. The court concluded that the fit between race and quality of municipal service was so tight that it could infer racial classification by government. Presumably, under this approach, an inference of racial classification could be drawn in those circumstances where there could be no other reasonable explanation for the outcome. But the factual showing relating race and benefits must be extraordinarily perfect under this test, and no other reported municipal services case seems to have met these stringent requirements. See, e.g., Village of Arlington Heights v. Metropolitan Housing Development Corp., 429 U.S. 252, 266 (1977); Beal v. Lindsay, 468 F.2d 287 (2d Cir. 1972).

368. See, e.g., Pasadena City Board of Educ. v. Spangler, 423 U.S. 161 (1976).

369. The problem in the Denver case was to determine the appropriate scope of any remedy. In order to warrant district-wide relief, the predicate for such must be ascertained. The proof showed official discrimination in one predominantly hlack area through manipulation of school attendance zones and selection of school sites and sizes. The proof also showed a pattern of racial segregation in the core city, but without supporting evidence of discriminatory actions. Justice Brennan for the majority formulated two methods by which system-wide de jure segregation could be established.

First, where there is evidence that school authorities have systematically segregated a substantial proportion of the district, a court can use "common sense" to conclude that there is a reciprocal impact on other areas within the district. This warrants a finding that the entire district is segregated, unless the school officials can demonstrate that the district is divided into separate and identifiable units, unrelated to and unaffected by the illegally segregated area.

Second, a showing of intentional segregation in a significant part of the district is probative on the question of intent in other areas of the district where racial segregation exists. Thus, the observed segregation in the core city was presumed to result from intentional acts of school officials, unless they could disprove the presumption of impermissible governmental action. Keyes v. School Dist. No. 1, 413 U.S. 189, $213-14$ (1973). See also Dayton Board of Educ. v. Brinkman, 45 U.S.L.W. 4910 (U.S. June 27, 1977).

370. See Milliken v. Bradley, 418 U.S. 717,745 (1974). The Court in Milliken refused to permit inferences of intent to apply to different (i.e., suburban) school districts, and declined to in- 
Similarly, the Court rejected a claim that a program that treated AFDC recipients (predominantly blacks and Mexican-Americans) worse than other categorical assistance beneficiaries resulted in a racial classification; ${ }^{371}$ it found the "naked statistical argument" 372 unpersuasive since that approach would render unacceptably suspect "each difference in treatment among the grant classes, however lacking in racial motivation and however otherwise rational the treatment might be." ${ }^{373}$

More recently, in Washington v. Davis, ${ }^{374}$ the Court has explicitly rejected the view that "a law or other of ficial act . . . is unconstitutional solely because it has a racially disproportionate impact." ${ }^{375}$ Even though the parties argued the case as though disproportionate impact alone could serve as the basis for demonstrating a race-based classification, the Court did not feel bound by the parties' analysis since failure to present the appropriate issue constituted "plain error" under Supreme Court rules. ${ }^{376}$

Washington was a constitutional challenge to the validity of a qualifying test administered to applicants for positions as police officers. Plaintiffs showed that four times as many blacks as whites failed the test, and the District of Columbia Circuit Court of Appeals found that the disproportionate racial impact, "standing alone and without regard to whether it indicated a discriminatory purpose," 377 was sufficient to establish a racial classification. The Supreme Court, reversing, noted that the equal protection clause sought to prevent official, racially discriminatory conduct: "[T] he invidious quality of a law claimed to be racially discriminatory must ultimately be traced to a racially discriminatory purpose." ${ }^{378}$ Therefore, in order to trigger the strict scrutiny that is accorded racial classifications, there must be some showing of intent. Evidence of disproportionate impact is relevant, since an impermissible purpose may be "inferred from the totality of the relevant facts, including the fact .. . that the law bears more heavily on one race than another." ${ }^{379}$ But governmental action, neutral on its face and seeking otherwise legitimate ends, is not invalid simply because of its unequal effect on different races. ${ }^{380}$

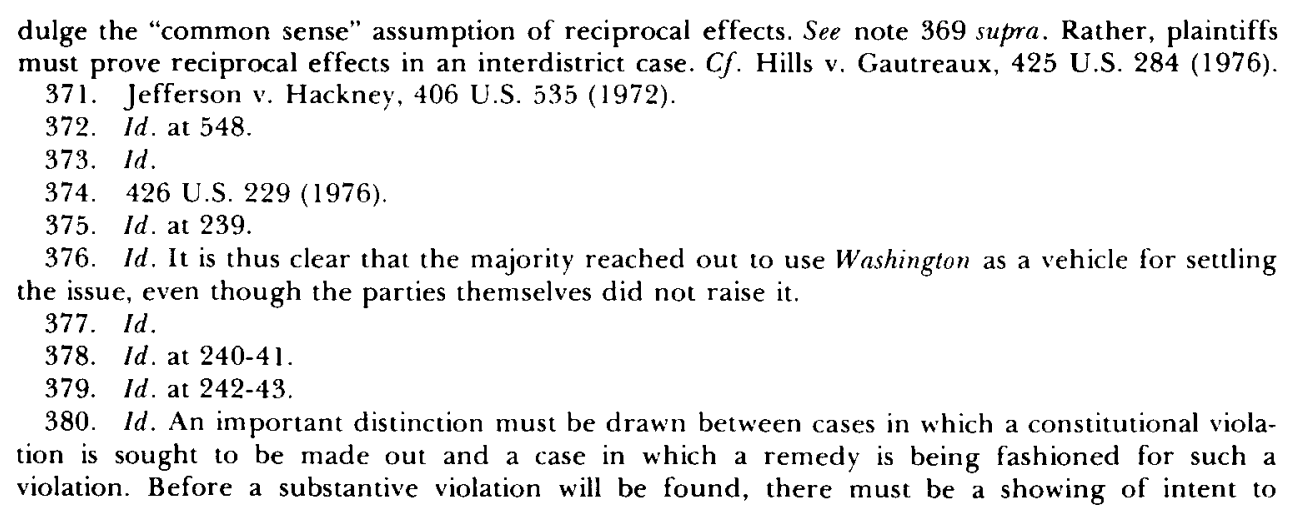


Disproportionate impact is not irrelevant, but it is not the sole touchstone of an invidious racial discrimination forbidden by the Constitution. Standing alone, it does not trigger the rule . . . that racial classifications are to be subjected to the strictest scrutiny and are justified only by the weightiest considerations.

Consider the implications of the above analysis in the life-valuing context. Suppose that governmental research priorities are changed, and the sickle cell anemia program is terminated. Since only blacks are susceptible to the disease, the effect of halting the research program would follow strict racial lines. If this outcome were all that was needed to warrant a finding of racial classification, the decision to discontinue the sickle cell program would not be sustained. Under current doctrine, however, the evidence of impact, while probative, would be insufficient of itself to establish a race-based classification. ${ }^{381}$ The impact on blacks alone, however, might be sufficient to make out a prima facie case, shifting the burden of proof to the state to show plausible, nonracial justifications. ${ }^{382}$

If the government can demonstrate reasonable, nonracial grounds for terminating its sickle cell research efforts, it can successfully meet its burden, unless there is other evidence to support the claim of discriminatory intent. Thus, if it were shown that scarce research resources would likely save more lives if allocated to other, higher priority areas, that would likely suffice to justify the decision to terminate, despite the disproportionate effect such a

discriminate, which can be demonstrated by specific statements or acts of government officials, or by the natural consequences of such governmental action. See Keyes v. School Dist. No. 1, 413 U.S. 189, 208-09 (1973). Effect alone is insufficient to support a finding of discrimination.

However, in the remedies phase of an equal protection case, once a constitutional violation has been show'n, the Court has said that effectiveness is the critical factor. Attention will focus, therefore, not on intent or purpose, but on effect. If a remedy will not work, it will be inadequate, even if there is no showing of an intent to discriminate. See Hills v. Gautreaux, 425 U.S. 284 (1976); Swann v. Charlotte-Mecklenburg Board of Educ., 402 U.S. 1 (1971); Green v. County School Board, 391 U.S. 430 (1968).

This distinction has been of especial importance in school desegregation cases, where Justice Powell has criticized the current state of the law since northern cases curn on an analysis of purpose to determine whether there has been a constitutional violation while southern cases turn on a showing of effect since the original segregation statutes clearly established the racial classification. See Keyes v. School Dist. No. 1, 413 U.S. at 217 (Powell, J., concurring). See also Wright v. Council of the City of Emporia, 407 U.S. 451 (1972).

381. See Village of Arlington Heights v. Metropolitan Housing Development Corp., 429 U.S. 252 (1977); Washington v. Davis, 426 U.S. at 241-42 \& n.12; Palmer v. Thompson, 403 U.S. 217 (1971).

382. See Alexander v. Louisiana, 405 U.S. 625, 632 (1972); Keyes v. School Dist. No. 1, 413 U.S. at 208-11. Keyes imposes a formidable burden on state officials to show that segregation was not a result of discriminatory policies. Recognizing that segregative acts by school officials help create "a natural environment for the growth of further segregation," the Court conditions successful rebuttal of the presumption of segregative intent upon a "showing that . . past segregative acts did not contribute to the current segregated condition." Id. at 211 (emphasis added); see note 369 supra. 
decision would have on blacks. Some additional showing of racial intent would be necessary to trigger strict judicial review. ${ }^{383}$

However, what if the following were the articulated rationale? Medical research is funded as an investment in preserving economically productive human lives; acting in rational pursuit of that objective, government costbenefit analysts conclude that since, statistically, blacks as a group have poorer economic prospects than whites, a research program oriented toward curing a disease that afflicts only blacks should be cut back so the resources could be utilized elsewhere. Such a rationale would be the kind of race-based classification that would trigger the strictest judicial scrutiny. While economic productivity might be a permissible criterion by which to allocate scarce research funds, using race as a proxy for that standard is precisely the kind of underand overinclusive, blunt principle of classification that is constitutionally disallowed where the basis of distinction is suspect. If that goal is to be successfully pursued, more precise means would have to be identified and used. ${ }^{384}$

\section{c. Gender-Based Classifications}

While the Court has expressly found alienage ${ }^{385}$ and race $^{386}$ suspect as

383. Under title VIl of the Civil Rights Act, 42 U.S.C. $\$ 2000 \mathrm{e}$, which prohibits employment discrimination based on race or sex, the Court has held that a showing of disproportionate racial impact of an employment test imposes a burden of justification on the employer to show its job-relatedness. Purpose or motivation is not the critical variable. See Albemarle Paper Co. v. Moody, 422 U.S. 405 (1975); Griggs v. Duke Power Co., 401 U.S. 424, 432 (1971). In Washington v. Davis, 426 U.S. 229 , the Court expressly declined to apply the statutory standard to constitutional claims: "We are not disposed to adopt this more rigorous standard for the purposes of applying the Fifth and the Fourteenth Amendments in cases such as this." 1 d. at 247-48. The Court apparently feared the far-reaching consequences of applying the statutory standard as a constitutional benchmark. $I d$.

384. Dunn v. Blumstein, 405 U.S. 330 (1972); Shelton v. Tucker, 364 U.S. 479 (1960). Reliance on purpose or motivation as a basis for finding racial discrimination is not without its own problems. See, e.g., Palmer v. Thompson, 403 U.S. 217 (1971). Acceptance of any plausible, nonracial motivation will certainly place a premium on subterfuge and disingenuousness when government articulates the rationales of its policies. Indeed, in the area of Establishment Clause litigation, where religious "purpose" is one of the tests for unconstitutional state interference in religion, only seldom has a case turned on such a showing. See, e.g., Epperson v. Arkansas, 393 U.S. 97 (1968). In other Establishment Clause cases, the Court has been willing to accept some transparent arguments as legitimate state justifications for programs assisting church-supported schools. See, e.g., Committee for Pub. Educ. \& Religious Liberty v. Nyquist. 413 U.S. 756 (1973), relying instead on other tests for the holding of unconstitutionality. This has also been the result in situations where government purports to justify expression-curtailing action based on unrelated, legitimate policies. See California v. LaRue, 409 U.S. 109 (1972) (sustaining dress regulations, otherwise protected under the first amendment, as incidental to state regulation in an establishment holding a state liquor license); United States v. O'Brien, 391 U.S. 367 (1968) (sustaining severe criminal penalties for draft card burning).

385. See Nyquist v. Manclet, 45 U.S.L.W. 4655 (U.S. June 13, 1977); In re Griffiths, 413 U.S. 717 (1973); Sugarman v. Dougall, 413 U.S. 634 (1973); Graham v. Richardson, 403 U.S. 365 (1973). But see Mathews v. Diaz, 426 U.S. 67 (1976) (holding that the federal government has power to legislate on the basis of alienage under article I, section 8 of the Constitution, which gives Congress authority to legislate with respect to naturalization); see note 354 supra.

386. See note 357 supra. 
principles of classification, it has refused to accord that status to such other classification categories as illegitimacy ${ }^{387}$ and $\operatorname{sex}^{388}$ though these are nevertheless disfavored..$^{389}$ It is clear that the Court will exercise more rigorous review where it finds these bases of classification, but it has refrained from holding that either illegitimacy or sex will automatically trigger strictest judicial scrutiny.

Classifications based on illegitimacy are not likely to be utilized frequently in decisions that allocate scarce life-saving medical resources. ${ }^{390}$ Gender-based classifications, on the other hand, might well be contemplated as a criterion in resource allocation decisions. ${ }^{391}$ Where gender-based classification is alleged, the constitutional issues are made more complex because ambiguity exists at two levels: (a) initially whether a classification is gender-based; (b) and if so, whether a reviewing court will sustain it anyhow. Once a governmentally imposed $^{392}$ race classification is found, it is virtually certain that a court will invalidate $i^{393}{ }^{393}$ this is not true in the case of gender-based classifications.

As with classifications alleged to be race-based, courts must first determine whether state classificatory schemes are indeed gender-based. Geduldig $v$. Aiello, ${ }^{394}$ discussed earlier, sustained California's decision not to include normal pregnancies as covered disabilities within the state-run disability insurance program. The Court rejected the argument that California's exclusion of pregnancy reflected a sex-based classification. Speaking for the majority (six to three), Justice Stewart saw no reason why the state could not choose to cover only the risks it wished, especially since the selection of insured risks did

387. Mathews v. Lucas, 427 U.S. 495 (1976).

388. Schlesinger v. Ballard, 419 U.S. 498 (1975); Frontiero v. Richardson, 411 U.S. 677 (1973).

389. On illegitimacy, see Trimble v. Gordon, 97 S. Ct. 1459 (1977); Jimenez v. Weinberger, 417 U.S. 629 (1974); Weber v. Aetna Cas. \& Sur. Co., 406 U.S. 164 (1972); Levy v. Louisiana, 391 U.S. 68 (1968). On gender, see Craig v. Boren, 429 U.S. 190 (1976); Reed v. Reed, 404 U.S. $71(1971)$.

390. This form of categorization has typically been applied in determining rights of illegitimate offspring that are derived from their natural (though unmarried) parents. For example, in Labine v. Vincent, 401 U.S. 532 (1971), the Court upheld a state law dealing with intestate succession, subordinating the rights of acknowledged illegitimate children to those of legitimate children and relatives of the deceased. Cases which struck down such distinctions between legitimate and illegitimate children have dealt with such issues as recovery for the wrongful death of a parent, Levy v. Louisiana, 391 U.S. 68 (1968), and eligibility for death benefits of a parent under a workman's compensation statute, Weber v. Aetna Cas. \& Sur. Co., 406 U.S. 164 (1972).

391. For example, a decision to give priority to those likely to live longer conceivably could result in the adoption of a female-first policy for allocating scarce life-saving medical resources on the theory that statistical evidence shows longer longevity patterns for women than for men. The law of evidence admits such sex-specific data in assessing damages in a wrongful death action. $S$. SPEISER, Recovery for Wrongful DeAth $\$ 3.23$ (1975). See note 9 supra.

392. This governmental imposition is precisely the difference between de facto (constitutional) segregation and de jure (unconstitutional) segregation. See Pasadena City Board of Educ. v. Spangler, 423 U.S. 161 (1976); Keyes v. School Dist. No. 1, 413 U.S. 189 (1973).

393. See Washington v. Davis, 426 U.S. 229 (1976); Loving v. Virginia, 388 U.S. 1 (1967).

394. 417 U.S. 484 (1974). Accord, General Electric Co. v. Gilbert, 429 U.S. 125 (1976). 
not discriminate "against any definable group or class in terms of the aggregate risk program. There is no risk from which men are protected and women are not. Likewise, there is no risk from which women are protected and men are not." ${ }^{395}$ The Court thus concluded that pregnancy-a physical condition-was excluded from the list of compensable disabilities; and, while only women can become pregnant, the classification is not based on gender as such (many women do not become pregnant). For Justice Stewart, the California program drew distinctions between "pregnant women and nonpregnant persons," ${ }^{396}$ with the second category including many women. He concluded that "[a]bsent a showing that distinctions involving pregnancy are mere pretexts designed to effect an invidious discrimination against the members of one sex or the other, lawmakers are constitutionally free to include or exclude pregnancy from the coverage of legislation such as this on any reasonable basis, just as with respect to any other physical condition." 397

The Geduldig view of what does and does not constitute a gender-based classification might have significant consequences for several types of lifevaluing decisions. Under that test, evidence that government-established lower occupational safety standards for a job category primarily populated with women would not be more carefully scrutinized unless a showing could be made that the alleged justifications were "mere pretexts" designed to effect sex-based discrimination. ${ }^{398}$

On the other hand, a rule that granted preference for dialysis to "mothers of school-age children" could legitimately be found to be a gender-based classification, at least if raised by a father of school-age children. That probably would be the kind of gender-based classification "as such" that Justice Stewart described. ${ }^{399}$ The state's interest would be to distinguish between parents of school-age children and others, and the distinction between mothers and fathers would be purely sex-related. Unlike pregnancy, which has physical and financial characteristics apart from gender, preference for specified female parents reflects a decision to favor one sex over another. ${ }^{401}$

If it be assumed that a finding of gender-based classification is made, existing doctrine does not automatically dictate the outcome of a constitutional challenge. For example, an argument can be made that the preference for "mothers of school-age children" is a "benign" classification and therefore

395. Id. at $496-97$.

396. Id. at 497 n. 20 .

397. Id. at $496-97 \mathrm{n} .20$.

398. Id. at 496 n. 20 .

399. Id. at 497 n. 20 .

400. Cf. Stanley v. Illinois, 405 U.S. 645 (1972), where the Court struck down a law that permitted the state to declare the children of an unwed mother wards of the state upon her death without providing a hearing on the father's fitness as a parent; unwed mothers were entitled to such a hearing upon the death of the father. See also Reed v. Reed, 404 U.S. 71 (1971). 
should be sustained. The benign gender-based classification notion has recently been revived in a decision upholding a Florida provision granting widows, but not widowers, an annual property tax exemption of five hundred dollars. ${ }^{401}$ Applying a more relaxed standard of review, the Court found the distinction had a "fair and substantial relation" to the legitimate state policy of "cushioning the financial impact of spousal loss upon the sex for which that loss imposes a disproportionately heavy burden." ${ }^{402}$ The Court argued that Florida could redress the financial difficulties that were more acute for lone women than for men: "Whether from overt discrimination or from the socialization process of a male-dominated culture, the job market is inhospitable to the woman seeking any but the lowest paid job."403

The "benign" classification principle has not been pursued actively, however, and it is unlikely that it would justify the preference for mothers rather than fathers of school-age children. ${ }^{404}$ Thus, in Weinberger $v$. Wiesenfeld, ${ }^{405}$ the Court unanimously sustained a challenge to a provision of the Social Security Act under which wives and minor children of deceased husbands (and fathers) received survivors' benefits but only minor children (and not husbands) received benefits when a wife (and mother) died. ${ }^{406}$ In Wiesenfeld, the mother had been the principal source of support for the family, and the Court found an unjustifiable diminution in protection for women workers based solely on gender. ${ }^{407}$ The benignness argument was rejected; the "mere recitation of a benign, compensatory purpose is not an automatic shield which protects any inquiry into the actual purposes underlying a statutory scheme." ${ }^{088}$ Therefore, since men cannot be conclusively presumed to be disfavored as parents, ${ }^{409}$ since the classification does not involve a tax scheme (to

401. Kahn v. Shevin, 416 U.S. 351 (1974). See also Califano v. Webster, 97 S. Ct. 1192 (1977).

402. Id. at 355. It is noteworthy that Justice Douglas, who was one of four members of the Court in Frontiero v. Richardson, 411 U.S. 677 (1973), to label sex a "suspect" category, was the author of the opinion in Kahn $\%$. Shevin, announcing the benign classification doctrine. It is especially noteworthy since Justice Douglas almost simultaneously announced his strenuous opposition to preferential law school admissions standards for blacks, rejecting the benign classification concept in that context. See DeFunis v. Odegaard, 416 U.S. 312, 320 (1974) (Douglas, J., dissenting). 403. 416 U.S. at 353.

404. The Court relied not on the benignity of the classification, but on the special characteristics of the military in upholding a scheme which required discharge of men who had not been promoted within a certain time, while permitting a longei tenure for unpromoted women. In Schlesinger v. Ballard, 419 U.S. 498 (1975), the Court found that the kind of work women performed in the Armed Forces presented them with less opportunity for promotion, and they were therefore "not similarly situated" with the men. $I d$. at 508. The Court found "rationality" rather than "benignness" in this classification. Id. at 509. But see Califano v. Webster, 97 S. Ct. 1192 (1977).

405. 420 U.S. $636(1975)$.

406. 42 U.S.C. $\$ 402(\mathrm{~g})(1974)$.

407. 420 U.S. at 648 .

408. Id.

409. Stanley v. Illinois, 405 U.S. 645 (1972). 
which the Court traditionally shows utmost deference), ${ }^{410}$ and since the basis of classification is ultimately gender "as such," it was held invalid, especially since there was no showing of legitimate and important countervailing governmental interests.

The gender-based classification cases thus have potential significance as limitations on government freedom to make decisions which affect the value of life. The Court will still permit a wider variety of justifications to prevail in sex than in race cases. ${ }^{41}$ But it will not defer to legislative choices, even concerning resource allocation matters in social welfare programs, where the sole justification is a decision to treat the sexes differently. ${ }^{42}$ Accordingly, in Wiesenfeld the Court held that "noncontractual" 413 benefits "must be distributed according to classifications which do not without sufficient justification differentiate among covered employees solely on the basis of sex."414 Government cannot distinguish between men and women solely on the basis of gender, without other independent justifications, or without adequate reasons, such as the compensatory principle.

\section{Formulating Remedies: Institutional Limitations of Courts}

Once a court intervenes in the process by which government sets priorities, it must formulate an appropriate remedy. This section will focus on a variety of institutional limitations faced by courts in fashioning implementation orders.

\section{Determining Criteria}

Courts face significant problems in determining what criteria to use in formulating a decree. The prison, ${ }^{415}$ mental hospital, ${ }^{416}$ and municipal services $^{417}$ cases highlight the difficulty well. A finding of inadequate treat-

410. San Antonio Independent School Dist. v. Rodriguez, 41 l U.S. 1, 40-41 (1973); Lehnhausen v. Lake Shore Auto Parts Co., 410 U.S. 356, 359 (1973).

411. See, e.g., Schlesinger v. Ballard, 419 U.S. 498 (1975), where the Court found that different promotion systems in the armed forces were legitimate in light of the dissimilar situations of men and women with respect to opportunities for professional service. See notes $402 \& 404$ supra. In addition, admission of sex-specific data for determining the amount of damages in a wrongful death action has not been subjected to constitutional challenge. See generally S. SPEISER, RECOVERY For Wrongful DeAth $\S 3.23$ (1975).

412. See Califano v. Goldfarb, 97 S. Ct. 1021 (1977): Weinberger v. Wiesenfeld, 420 U.S. 636 (1975); Reed v. Reed, 404 U.S. 71 (1971). But see Califano v. Goldfarb, 97 S. C.t. 1021,1036 (1977) (Rehnquist, J., dissenting); Kahn v. Shevin, 416 U.S. 351 (1974).

413. 420 U.S. at 647

414. $I d$.

415. See generally Rhem v. Malcolm, 507 F.2d 333 (2d Cir. 1974): Newman v. Alabama, 503 F.2d 1320 (5th Cir. 1974); Holt v. Sarver, 442 F.2d 304 (8th Cir. 1974).

416. See generally Wyatt v. Aderholt, 503 F.2d 1305 (5th Cir. 1974); Davis v. Watkins, 384 F. Supp. 1196 (N.D. Ohio 1974); Welsch v. Likins, 373 F. Supp. 487 (D. Minn. 1974); Statchulak v. Coughlin, 364 F. Supp. 686 (N.D. Ill. 1973).

417. Beal v. Lindsay, 468 F.2d 287 (2d Cir. 1972). See generally Hawkins v. Town of Shaw, 461 F.2d 1171 (5th Cir. 1972). 
ment in incarceration facilities or unequal distribution of services requires a court to establish (or approve) ${ }^{418}$ a plan that will terminate the unconstitutional conditions. In the prison and mental hospital cases, for example, courts have issued decrees remarkable in their specificity. Requirements such as the following have been imposed: minimum floor space per patient, ${ }^{419}$ minimum staff size ratios and qualifications, ${ }^{420}$ "prompt and adequate medical treatment for any physical ailments,"421 renovated jail cells and new infirmary facilities, ${ }^{422}$ and even odor-free toilets. ${ }^{423}$ The opinion of Judge Johnson in Wyatt $v$. Stickney ${ }^{424}$ is a rather extraordinary piece of judicial handicraft. ${ }^{425}$ For

418. See notes 439-48 infra and accompanying text.

419. Wyatt v. Stickney, 344 F. Supp. 373, 381 (M.D. Ala. 1972).

420. Id. at 383-84.

421. Id. at 380 .

422. Taylor v. Sterrett, 344 F. Supp. 411,422 (N.D. Tex. 1972), aff'd in part, rev'd in part, 499 F.2d 367 (5th Cir. 1974).

423. Wyatt v. Stickney, 344 F. Supp. 373, 382 (M.D. Ala. 1972).

424. 344 F. Supp. at 387 , aff'd in part sub nom. Wyatt v. Aderholt, 503 F.2d 1305 (5th Cir. 1974).

425. District Judge Johnson's order is well worth sampling in detail since the flavor is lost in summary:

19. Physical Facilities

...

A. Resident unit.

The number of patients in a multi-patient room shall not exceed six persons. There shall be allocated a minimum of 80 square feet of floor space per patient in a multipatient room. Screens or curtains shall be provided to ensure privacy within the residential unit. Single rooms shall have a minimum of 100 square feet of floor space. Each patient will be furnished with a comfortable bed with adequate changes of linen, a closet or locker for his personal belongings, a chair, and a bedside table.

B. Toilets and Lavatories

There will be one toilet provided for each eight patients and one lavatory for each six patients. ... The toilets ... will be clean and free of odor. . .

C. Showers

There will be one tub or shower for each 15 patients. . .

D. Day Room

The minimum day room area shall be 40 square feet per patient. . .

E. Dining Facilities

The minimum dining room area shall be ten square feet per patient. . .

....

24. Staffing Ratios

The Hospital shall have the following minimum numbers of treatment personnel per 250 patients.

$\begin{array}{lr}\text { Unit Director } & 1 \\ \text { Psychiatrist (3 years' residency training in psychiatry) } & 2 \\ \text { MD (Registered physicians) } & 4 \\ \text { Nurses (RN) } & 12 \\ \text { Licensed Practical Nurses } & 6 \\ \text { Aide III } & 6 \\ \text { Aide II } & 16 \\ \text { Aide I } & 70 \\ \text { Hospital Orderly } & 10 \\ \text { Clerk Stenographer II } & 3 \\ \text { Clerk Typist } & 3\end{array}$


example, he finds that the Constitution mandates a specific staff size ratio (more than two hundred personnel for each two hundred fifty patients), apparently without considering the wealth or tax base of the state, or investigating and evaluating the opportunity costs.

Similar problems arise when courts are faced with remedying unconstitutionally unequal municipal services. In Hawkins v. Town of Shaw, ${ }^{\mathbf{4 2 6}}$ which dealt with racial discrimination in the delivery of municipal services, the Fifth Circuit remanded to the district court to fashion a remedy. But Judge Clark in dissent somberly observed that "[h]ard reality fore-ordains that no plan can be devised which will solve the complex variables of 'equalizing' municipal services." ${ }^{427}$ Noting that the city's resources are finite, and that other demands will be made on those resources over time, ${ }^{428}$ the dissent cogently asked what

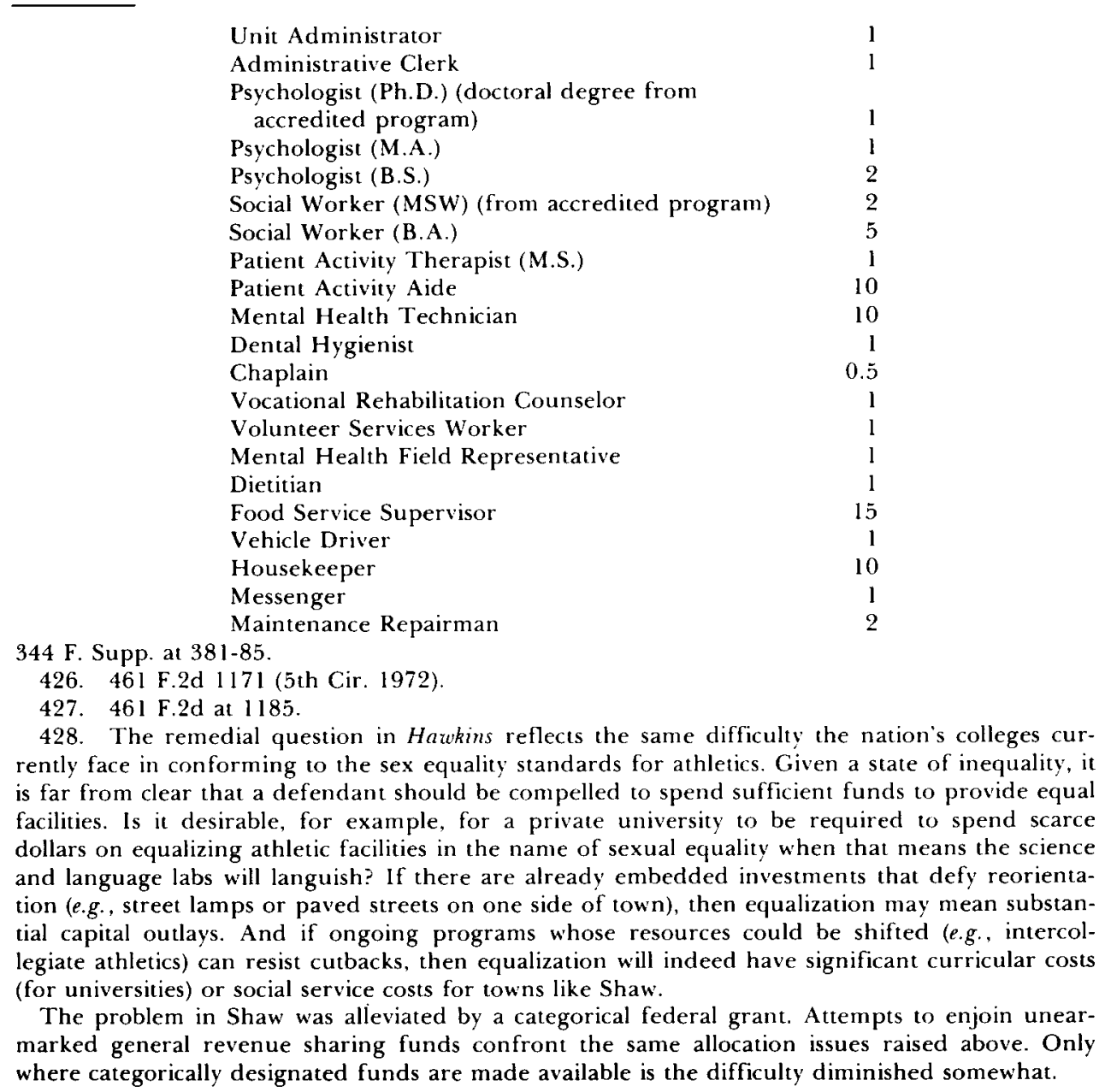


criteria of equality will be required and based on circumstances at what point in time. ${ }^{429}$

The problem is that formulating a policy to remedy inadequate treatment facilities or to equalize municipal services requires consideration of multifarious factors. ${ }^{430}$ This is the type of open-ended policy formulation role that courts traditionally eschew because of the absence of clearly identified bright lines or fundamental values that usually guide their actions. In certain contexts, these concerns have led the judiciary to withdraw from the arena on the grounds of institutional incompetence, finding issues of this type nonjusticiable. ${ }^{431}$ Where courts have chosen to intervene, however, they continue to confront the very real problems of making policy decisions based on the resolution of multi-dimensional issues and values. ${ }^{432}$

The difficulty of perceiving guidelines for implementing decrees, and the concomitantly broad discretion vested in a court, raise questions concerning the legitimacy of judicial intervention. ${ }^{433}$ This reflects the constant tension between our society's democratic ideals, which dictate political accountability, and its written constitution, which implants the judiciary as a barrier to the potential excesses of rampant majoritarianism, safeguarding basic values from the whims of momentary majorities. ${ }^{434}$

\section{Narrow Analytical Horizons}

The lack of standards, however, is only one facet of the institutional problems courts confront when formulating remedial decrees in these kinds of cases. Another important limitation is the necessarily narrow expanse of a court's analytical horizon. Courts deal with live cases and controversies which center on the grievances of specific parties and their particularized constitutional claims. In the Alabama mental hospital case, the state argued that im-

429. 461 F.2d at $1185-86$.

430. Cf. F. Michelman \& T. Sandalow, Government in Urban Areas 495-500, 646-64 (1970)

431. See generally Baker v. Carr, 369 U.S. 186 (1962). See also Baker v. Carr, 369 U.S. at 266 (Frankfurter, J., dissenting); Luther v. Borden, 48 U.S. (7 How.) 1 (1849).

432. Illustrative cases come from the areas of (1) voting, see, e.g., Gaffney v. Cummings, 412 U.S. 735 (1973); Mahan v. Howell, 410 U.S. 315 (1973); Whitcomb v. Chavis, 403 U.S. 124 (1971); and (2) school desegregation, see, e.g., Pasadena City Board of Educ. v. Spangler, 423 U.S. 161; Milliken v. Bradley, 418 U.S. 717 (1974); Keyes v. School Dist. No. 1, 413 U.S. 189 (1973).

433. See generally Wechsler, Toward Neutral Principles of Constitutional Law, 73 HARv. L. REv. I (1959); cf. Blumstein, The Supreme Court's Jurisdiction-Reform Proposals, Discretionary Review, and Writ Dismissals, 26 VAND. L. Rev. 895, 914-16 (1973); Deutsch, Neutrality, Legitimacy, and the Supreme Court: Some Intersections Between Law and Political Science, 20 STAN. L. Rev. 169 (1968).

434. See, e.g., West Va. Board of Educ. v. Barnette, 319 U.S. 624, 638 (1943): "The very purpose of a Bill of Rights was to withdraw certain subjects from the vicissitudes of political controversy, to place them beyond the reach of majorities and officials and to establish them as legal principles to be applied by the courts." 
plementation of the district judge's order would require massive state expenditures, either curtailing other worthwhile state programs or raising taxes -options which the state was unwilling to adopt and choices which, it contended, should be made by the politically accountable branches of state government. ${ }^{435}$

The Fifth Circuit was unpersuaded, holding that budgetary factors were insufficient justification for not providing treatment mandated by the court. ${ }^{436}$ Moreover, if the state should fail to act in good faith to carry out the decree, the possibility was left open for the court to take other steps-appointing a master to sell or encumber state lands, if necessary, in order to finance the required expenditures, or joining other state departments as parties to the lawsuit so that the court could enjoin expenditures for "nonessential" state functions, thereby effectively re-writing the state budget. ${ }^{437}$

Budget, administrative, and legislative officials must make similar types of judgments, but they, unlike courts, have authority to weigh alternatives and indeed must resolve conflicting claims for resources on a comparative basis. Three different types of allocative issues must be considered in the budgetary process: (1) Are increased funds for, say, the kidney program to come from an alteration in the degree of public versus private spending (i.e., a tax increase)? (2) Are those funds to come from other state agencies (i.e., more kidney machines and fewer police officers)? (3) Are the funds to come from other programs within the department itself (i.e., more kidney machines and fewer flu shots) ${ }^{\mathbf{4 3 8}}$ These are the kinds of trade-offs that politically accountable officials must consider, but courts are normally ill-equipped to factor those other priorities into their process of decision making. They do not take evidence on these issues, have jurisdiction only over the parties to a lawsuit, and have fewer guideposts for determining either what should be given up in order to effectuate a decree or how much must be spent to remedy a constitutional violation.

Moreover, since courts will typically focus primarily on the inadequacies of the department being sued, there is the possibility that the judiciary will be used by dissatisfied bureaucrats as an end-run around normal budget-making procedures. Indeed, it is quite apparent that a defendant department may very well see such a lawsuit as an opportunity for it to secure more funds than it might otherwise receive in the budget derby and therefore look on the suit as a friendly one. ${ }^{439}$

435. Wyatt v. Aderholt, 503 F.2d 1305, $1314-15$ (5th Cir. 1974).

436. Id.; $c f$. Frontiero v. Richardson, 411 U.S. 677, 688-91 (1973); Shapiro v. Thompson, 394 U.S. 618, 633-38 (1969); note 295 supra and accompanying text.

437. Wyatt v. Aderholt, 503 F.2d at 1314-15. See generally Milliken v. Bradley, 45 U.S.L.W. 4873 (U.S. June 27,1977 ).

438. See note 237 supra.

439. See, e.g., Milliken v. Bradley, 45 U.S.L.W. 4873, 4880 (U.S. June 27, 1977) (Powell, J., 
Indeed, at the remedial stage, the formulation of the decree necessarily draws on the expertise of the defendant department's staff and other professional experts who are likely to testify to a professional standard of "need."440 But concepts of "needs" 441 as defined by professional associations, are notoriously uninfluenced by considerations of economic trade-offs. ${ }^{442}$ Professionals within a defendant department, frustrated by the budgetary compromises made essential by the competition with other claims on scarce resources, may welcome an opportunity to dramatize their arguments in a forum where theirs is the only financial claim under scrutiny. ${ }^{\mathbf{4 4 3}}$ In this way, a court, without authority to consider macro allocation questions, and therefore facing a "yes/no" question, ${ }^{\mathbf{4 4}}$ will likely be more receptive to the proffered "needs" standard sought by plaintiffs and their professional allies than will other budget officials, who face "either/or" decisions. ${ }^{445}$

In Wyatt, the Alabama mental hospital case, the court in fact relied heavily on detailed standards established by national professional organizations which appeared as amici curiae. ${ }^{\mathbf{4 6}}$ And the defendant department cooperatively agreed that the standards set by the court were desirable from its perspective. ${ }^{447}$

concurring); Pennsylvania Ass'n of Retarded Children v. Pennsylvania, 343 F. Supp. 279 (E.D. Pa. 1972) (consent decree); Kirp, Buss, \& Kuriloff, Legal Reform of Special Education: Empirical Studies and Procedural Proposals, 62 Calif. L. Rev. 40, 59 (1974). See also Note, The Wyatt Case: Implementation of a Judicial Decree Ordering Institutional Change, 84 YALE L.J. 1338, 1367-68 \& nn.180-81 (1975) (hereinafter cited as Note, The Wyatt Case).

440. See Note, The Wyat Case, supra note 439 , at 1348 \& n.49.

441. A "need" reflects a professional judgment concerning the quantity and quality of specified services that a population should consume over a period of time. Thus, a

given population's need for medical services from the standpoint of the medical profession relates to that quality of medical services that expert medical opinion regards as available and necessarily rendered to enable its members to meet contemporary standards of good health. This concept of need is independent of economic considerations, i.e., independent of prices of medical services; financial resources, including insurance; and so on.

Jeffers, Bognanno, \& Bartlett, On the Demand Versus Need for Medical Services and the Concept of "Shortage," 61 Aм. J. Pub. Health 46, 50-51 (1971). See generally Boulding, The Concept of Need for Health Services, in Economic Aspects of Health Care 3 (J. McKinlay ed. 1973).

442. Blumstein, supra note 1, at 265-67; Havighurst \& Blumstein, supra note 1, at 25-28.

443. See Note, The Wyat Case, supra note 439 , at 1367 . In response to the district judge's order that the parties submit proposed minimum standards for adequate treatment, the defendants, plaintiffs, and mental health amici stipulated over 90 per cent of the required standards. "Moreover, once the Court recognized that a right to treatment existed, Dr. Stickney began to regard the decree as a method of obtaining increased financial support from the Governor and state legislature." Id. \& n. 179.

444. See Havighurst \& Blumstein, supra note 1, at 33-34, 36, 50-51; notes 133 \& 225 supra.

445. Central state administrators may, in turn, retaliate against departmental officials who use the suit too aggressively to increase their budget allocations or too overtly lend comfort to plaintiffs' claims. See Note, The Wyatt Case, supra note 439, at $1353 \mathrm{nn} .75$ \& 76 . $C f$. Milliken v. Bradley, 45 U.S.L.W. 4873, 4880-82 (U.S. June 27, 1977) (Powell, J., concurring) (city school board accepted court-ordered remedial plan, but state officials resisted paying to city state's share of excess costs).

446. See Note, The Wyat Case, supra note 439.

447. Id. at $1367-69$. 
Yet it is likely-and reasonable-that politically accountable officials could choose not to fund a treatment program at the level recommended by professional advocates for top quality treatment facilities, ${ }^{488}$ especially in a relatively poor state such as Alabama where other high priority items might have to be deleted from the government's agenda in order to fund what would probably be one of the fanciest mental hospital systems in the nation. ${ }^{449}$

\section{Conclusion}

This discussion, then, suggests the desirability of judicial restraint concerning the allocation of life-saving medical resources, where such delicate and symbolically important values are implicated. Once involved, courts (even more than other governmental entities) have an understandably difficult time avoiding the effects of symbolic devotion to the preservation of life at any cost. ${ }^{450}$ On the other hand, courts do have an important role to perform as guardians of fundamental values, and this may require some forms of intervention to preserve human life. ${ }^{451}$ But the nature of case by case, ad hoc adjudication in a limited adversarial setting ${ }^{452}$ inevitably places courts in the position of the trial judge in the Quinlan case, where realistic appraisal of competing options is virtually impossible.

It is this institutional limitation-and the courts' especial susceptibility to symbolic blackmail-that should lead to a search for "mediating devices" 453 by

448. See Havighurst \& Blumstein, supra note 1 , at 6 \& n.l, $25-28$ (discussing the "quality imperative" - the professional bias toward higher quality irrespective of cost).

449. In the Wyatt case, Governor Wallace opposed increasing allocations for mental health programs even though he purported to agree with the "ultimate achievement of the standards and goals for mental health facilities" that had been ordered by the district court. Note, The Wyatt Case, supra note 439 , at 1369 n.189. Another important consideration in evaluating judicial formulation of such decrees is the question of evolving modes of treatment. Eleven million dollars of Alabama's revenue sharing funds were released to the Mental Health Board, id. at 1369, and during 1972-74 more than one million dollars were spent on capital improvements. Id. at 1372 n.200. The type of expenditure made by a mental health agency may reflect differing attitudes about the competing philosophies of improved institutionalized care versus deinstitutionalization. A court decree that requires extensive new construction runs the risk of imposing massive expenditures that may prove useless in short order. See id. at 1371-73, 1379.

450. There is another institutional factor that also warrants some attention. Since courts do not have authority to raise funds on their own, or even to shift funds from one department to another unless both units are joined as parties in a lawsuit, they must ultimately rely on defendant agencies and state government to acquiesce, either out of respect or through intimidation. Where courts impose allocation priorities, they therefore risk impairing their own institutional credibility and their political stature if a recalcitrant defendant refuses to appropriate sufficient funds or otherwise aggressively resists judicial action. Such defendants who vigorously oppose implementation of judicial decrees-school boards fighting busing orders for example-have a potent political weapon that could help undermine public support for court interventions. They can place the court in a very unfavorable light by closing out popular and visible programs, like football, in order to galvanize popular opposition to judicial action.

451. See, e.g., section II.B. supra.

452. See notes $233 \& 327$ supra.

453. See generally Bickel, supra note 130 , at 50-51. 
which the judiciary can gracefully decline to resolve certain issues on their constitutional merits. In so doing courts would simultaneously sidestep the adoption and implementation of costly rules in the service of symbolic solicitude for human life and avoid validating or legitimating political decisions that might conflict with basic societal values. ${ }^{454}$ This low judicial profile will allow society to modify its own approach to tragic choices, paying homage seriatim to the various competing and conflicting values that arise. This is Calabresi's vision of societal accommodation to "tragic choice" situations-a recognition that any decision-making procedure will tread on basic values, and that only a continual shifting from one system to another will be able to preserve intact values which, for a time, must be ignored. ${ }^{455}$ Judicial validation of any one in a series of such choices runs the risk of entrenching and solidifying compromises that may be temporary or unstable.

Indeed, the Supreme Court itself faces an institutional "tragic choice." Either by restricting government power to limit resources allocated to lifesaving technology, or by validating such difficult choices, the Court, regardless of what it intends, can generate political consensus or acquiescence-and "may impart permanence." 456 Thus, courts should develop and use flexible mechanisms that allow some form of intervention where relatively clear constitutional values are breached (e.g., race classifications) and where remedies are relatively easier to fashion, but which retain the ability to decline ultimate resolution of sensitive issues on their constitutional merits where validation or legitimation would have serious symbolic costs. ${ }^{457}$

454. Id. at 48 .

455. See G. Calabresi, Tragic Choices, supra note 13.

456. Bickel, supra note 130 , at 48 .

457. While it is beyond the scope of this article to explore further the devices courts could use to maintain a low profile, it is appropriate to mention several that have promise.

(1) State action. Since a finding of state action is a prerequisite to invocation of constitutional safeguards under the fourteenth amendment, re-examination of that concept is one means of delimiting judicial intervention. For years, the Court has sought to define the line between governmental and private responsibility, primarily in the context of racial discrimination. Until the major civil rights legislation of the 1960 s was in place, claims of discrimination by aggrieved blacks could not be sustained unless governmental responsibility were somehow demonstrated. In conformity with the Warren Court's weltanschauung that government should bear responsibility for a greater part of the nation's social ills, the state action principle was applied expansively. In recent years, however, the Court has backed away from the more far-reaching decisions of the 1960 s, finding itself increasingly willing to ascribe behavior as within the realm of private activity and therefore not subject to constitutional limitations. See, e.g., Pasadena City Board of Educ. v. Spangler, 423 U.S. 161 (1976); Jackson v. Metropolitan Edison Co., 419 U.S. 345 (1974); Lloyd Corp. v. Tanner, 407 U.S. 551 (1972); Moose Lodge No. 107 v. Irvis, 407 U.S. 163 (1972); Evans v. Abney, 396 U.S. 435 (1970). What this trend means is that government may well be able successfully to implement the strategy of keeping distance between itself and the ultimate decision on life or death. In the Warren era, this technique might have been held ineffective because of some affirmative duty to perform a "governmental function," see, e.g., Evans v. Newton, 382 U.S. 296 (1966), but the Burger Court seems disinclined to extend such positivistic notions and indeed may very well have interred the concept in a recent decision. See Hudgens v. NLRB, 424 U.S. 507 (1976), overruling Amalgamated Food Employees Union v. Logan Valley Plaza, 391 U.S. 308 (1968). 
While avoidance of constitutional scrutiny by skirting the state action requirement does have its appeal in this context, there certainly are significant risks about this approach stemming from the unsatisfactory nature of the state action doctrine. Since the presence of state action is necessary for any constitutional scrutiny under either due process or equal protection, a finding of no state action insulates conduct from judicial review under constitutional precepts irrespective of the substantive character of the claim. Yet, there surely are substantive outcomes so unacceptable that, if demonstrated, their social costs would exceed the benefits of decentralization and governmental distancing. While decentralized decision making necessarily contemplates some inconsistency and perceived unfairness in individual cases, the possibility of patterns of wholesale (and unreviewable) discrimination is deeply troubling.

Fortunately, there are two tentative responses to these concerns. First, the circuit courts of appeal have in practice, if not in theory, applied different standards of state action where racial discrimination is involved. See note 44 supra. To some extent, this reflects a gradual modification of the concept, recognizing varying degrees of governmental responsibility in different contexts. See generally Black, supra note 365; Lloyd Corp. v. Tanner, 407 U.S. 551 (1972). Secondly, and perhaps more importantly, the extensive civil rights legislation of the $1960 \mathrm{~s}$, see, e.g., 42 U.S.C. $\S 2000 a$ (1974) (public accommodations); 42 U.S.C. $§ 2000 \mathrm{~d}$ (1974) (federal financial assistance); 42 U.S.C. \$ $2000 \mathrm{e}$ (1974) (employment); 42 U.S.C. $\$ 3601$ (1974) (housing), and the judicial reinvigoration of the Reconstruction Era Civil Rights Acts, see, e.g., Runyon v. McCrary, 427 U.S. 160 (1976); Jones v. Alfred H. Mayer Co., 392 U.S. 409 (1968), make most private discrimination illegal in the life-saving resources area. A finding of no state action, therefore, will not serve as a barrier to judicial review of cases involving most unacceptable forms of private conduct. And even without constitutional obligation, virtually all hospitals will feel some public pressure not to make decisions arbitrarily and will adopt procedures they can defend. Other than constitutional constraints, a hospital still faces possible legal attack for tortious conduct, and staff members must always bear in mind potential criminal responsibility. Thus, it seems that other operative social and legal controls largely obviate the need for the additional protection afforded by application of constitutional safeguards in this sensitive area.

(2) Privacy. The evolving constitutional right of privacy, as developed in the abortion cases, Planned Parenthood of Cent. Mo. v. Danforth, 428 U.S. 52 (1976); Doe v. Bolton, 410 U.S. 179 (1973); Roe v. Wade, 410 U.S. 113 (1973) and as applied in the Quinlan decision, 70 N.J. 10, 355 A.2d 647 (1976), would allow an increased role for private, decentralized decision making. This would permit non-governmental entities (individuals, families, physicians, and hospital committes) to make choices that democratic government may be unable to make and that we may not want government to make. For further exploration of this idea, see Tribe, The Supreme Court, 1972 Term-Foreword: Toward a Model of Roles in the Due Process of Life and Law, supra note 22; Havighurst, Blumstein, \& Bovbjerg, supra note 33.

(3) Procedural Equal Protection. Because of the difficulty of identifying acceptable criteria for distinguishing among competing transplant patients, because of the symbolic difficulty of judicial endorsement of such standards, and because of the significant budgetary consequences of disallowing application of some allocative technique, a court might conclude that an examination of procedural fairness rather than substantive criteria of classification would be appropriate. See generally Zeckhauser, Valuing Lives, supra note 7 . There is a procedural strain to equal protection in cases where the typical "disadvantageous distinction" model might be inapplicable; Professor John Ely has used the problem of jury selection to illustrate the situation. See Ely, supra note 243.

A state need not justify the selection of specific jurors by showing that the ones chosen were more qualified (whatever that might mean) than jurors not selected. All a state need show is that the system by which jurors are picked is free from impermissible bias, and that it is a rational procedure. In cases such as jury selection, legislative goals (Ely labels them "discretionary goals") are so amorphous that their very definition depends on the decision maker's value preferences. Accordingly, the relation between such a goal and various choices cannot be evaluated as rational or irrational. This strand of equal protection would be appropriately applied, therefore, to judge the legitimacy of a procedure for allocating scarce resources without requiring a court to evaluate (or endorse) substantive goals. For competing claimants for an organ transplant, this model would allow a lottery, even though the outcome might not, after the fact, seem to be rational. It would also allow a variety of different procedures, which would allow sequential accommodations to different values in "tragic choice" situations. See note 455 supra and accompanying text. 
